\title{
Stratigraphic and structural analysis of the J1 Sandstone, Scotts Bluff Trend, Scotts Bluff and Morrill counties, Nebraska
}

Jeremy M. Wolpert

West Virginia University

Follow this and additional works at: https://researchrepository.wvu.edu/etd

\section{Recommended Citation}

Wolpert, Jeremy M., "Stratigraphic and structural analysis of the J1 Sandstone, Scotts Bluff Trend, Scotts Bluff and Morrill counties, Nebraska" (2006). Graduate Theses, Dissertations, and Problem Reports. 2393. https://researchrepository.wvu.edu/etd/2393

This Thesis is protected by copyright and/or related rights. It has been brought to you by the The Research Repository @ WVU with permission from the rights-holder(s). You are free to use this Thesis in any way that is permitted by the copyright and related rights legislation that applies to your use. For other uses you must obtain permission from the rights-holder(s) directly, unless additional rights are indicated by a Creative Commons license in the record and/ or on the work itself. This Thesis has been accepted for inclusion in WVU Graduate Theses, Dissertations, and Problem Reports collection by an authorized administrator of The Research Repository @ WVU. For more information, please contact researchrepository@mail.wvu.edu. 


\title{
STRATIGRAPHIC AND STRUCTURAL ANALYSIS OF THE J1 SANDSTONE, SCOTTS BLUFF TREND, SCOTTS BLUFF AND MORRILL COUNTIES, NEBRASKA
}

\author{
Jeremy M. Wolpert \\ Thesis Submitted to the \\ College of Arts and Sciences \\ at West Virginia University \\ in Partial Fulfillment of the Requirements \\ for the Degree of \\ Master of Science \\ in \\ Geology
}

\author{
Richard Smosna, Ph.D., Chair \\ David Oldham, Ph.D. \\ Thomas Kammer, Ph.D. \\ Department of Geology and Geography \\ Morgantown, West Virginia \\ 2006
}

Keywords: Scotts Bluff Trend, J Sandstone, Lower Cretaceous, Dakota Group, Denver Basin, Nebraska 


\title{
ABSTRACT
}

\section{STRATIGRAPHIC AND STRUCTURAL ANALYSIS OF THE J1 SANDSTONE, SCOTTS BLUFF TREND, SCOTTS BLUFF AND MORRILL COUNTIES, NEBRASKA}

\author{
Jeremy M. Wolpert
}

Scotts Bluff Trend is a group of 10 oil fields that produce from the Cretaceous $\mathrm{J}$ Sandstone. Production was previously thought to be aligned along this trend due to structural influence.

For this study well logs were utilized in analyzing structural and stratigraphic elements, as well as hydrocarbon predictability. The Scotts Bluff Trend appears to sit upon a residual structural high. A comprehensive look reveals that stratigraphic influence is superimposed on the structural high.

J1 Sandstone reservoirs were mapped assuming a NW - SE depositional trend. Deposition was in a shallow-marine bar environment. Central-bar, bar-margin and interbar facies are recognized which interfinger laterally into the surrounding trapping siltstone.

A predictor of hydrocarbons was attempted by way of resistivity mapping. Although unsuccessful, use of these resistivity maps in conjunction with structural and stratigraphic maps has led to the recognition of at least seven prospects. 


\section{ACKNOWLEDGMENTS}

I would like to extend my sincerest appreciation to my advisor Dr. Richard Smosna. He has provided endless insight and encouragement for this project. Thanks for your belief in me when I didn't have it. Your mentoring will prove useful even outside the world of geology. Also instrumental was Dr. David Oldham. Thank you for the endless conversations, support and wisdom. You have provided me with endless tools for my professional career. Maybe one day we'll share a glass of champagne over a wellhead. To Dr. Thomas Kammer, thank you for your close scrutiny of this project. You truly have made this work extremely better with your review.

Additionally I would like to pay thanks to Equitable Supply and Seneca Resources Corporation for their support and patience throughout this entire process.

Thank you mom for your life-long encouragement and support in all the things I have accomplished. Your guidance and ideals will be with me everywhere I go.

To my supportive wife, Alisha. With out you, I would have failed many times over. You have been my biggest supporter. Thank you for the encouragement and patience over the last two years. And remember, no more late nights with me at work plugging away.

Lastly and most importantly, to my Savior and Lord of My Life, Jesus Christ. Thank you for the blessings you bestow upon me, even though I am unworthy. I am indebted to you for eternity.

"Jesus answered, "I am the way and the truth and the life. No one comes to the Father except through me..."

John 14:6 


\section{TABLE OF CONTENTS}

Page

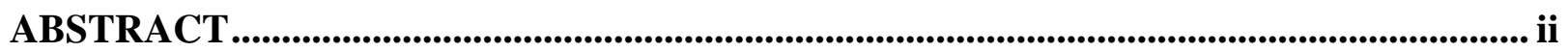

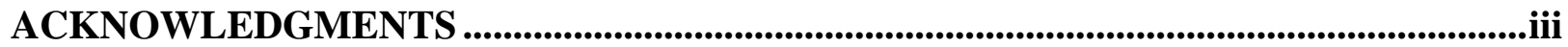

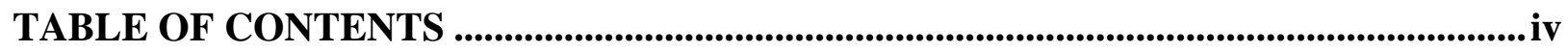

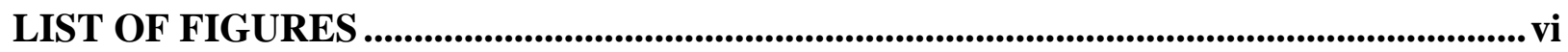

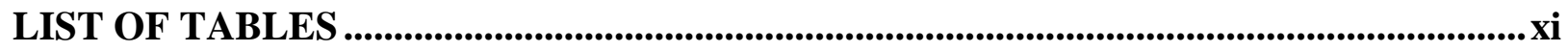

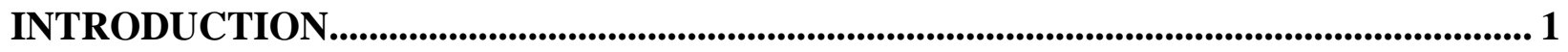

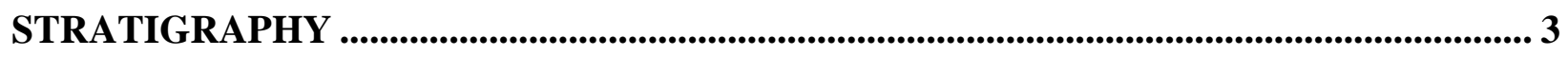

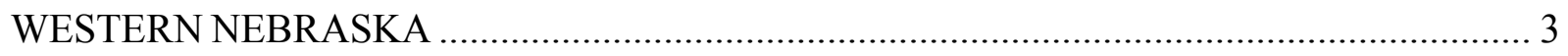

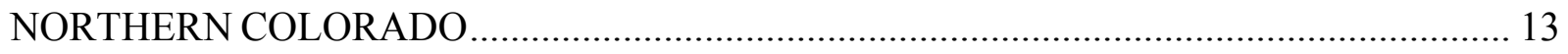

OIL MATURATION AND MIGRATION ...................................................................................... 24

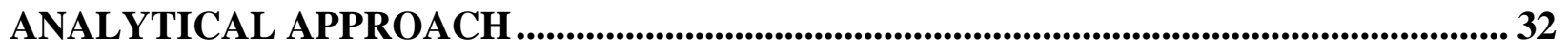

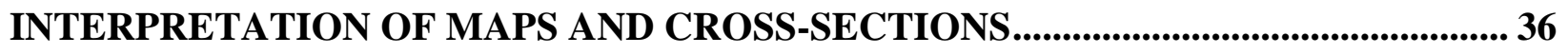

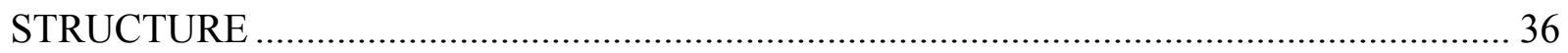



$2^{\text {nd }}$ ORDER RESIDUAL MAP OF THE J SANDSTONE STRUCTURE ........................... 42



ISOPACH OF HUNTSMAN SHALE MARKER TO J SANDSTONE................................ 46

ISOPACH OF NET J1 SANDSTONE - NO BIAS .................................................... 48

ISOPACH OF NET J1 SANDSTONE - GEOLOGIC BIAS ........................................... 50

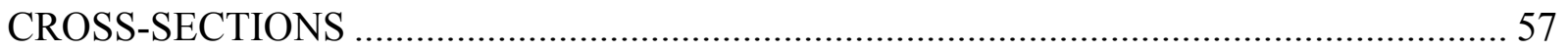

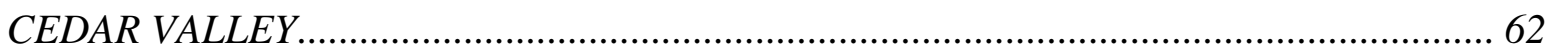

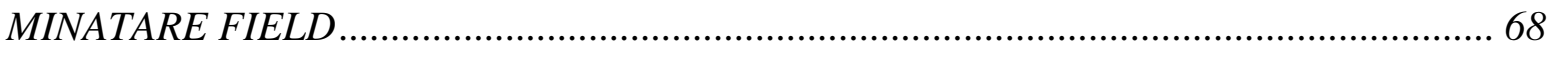

EXPLORATORY PREDICTORS ............................................................................... 75

MAXIMUM RESISTIVITY - ALL WELLS ........................................................ 75

MAXIMUM RESISTIVITY - NON PRODUCERS ONLY …..................................... 78

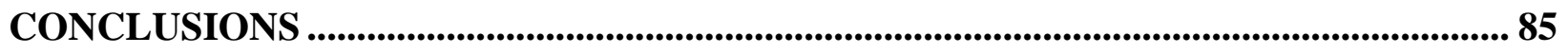




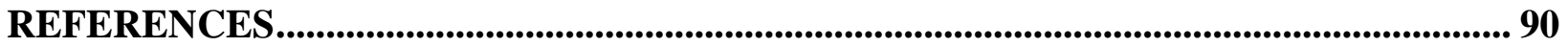

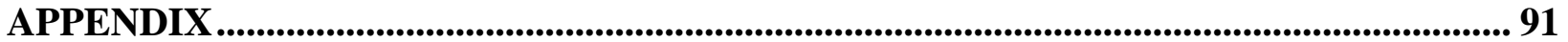




\section{LIST OF FIGURES}

Page

Figure 1: Map showing the 10 oil fields that comprise the Scotts Bluff Trend. Shown for each field is the production through 1987 (from Silverman, 1988). 2

Figure 2: Stratigraphic column of the Denver basin. Targeted formations in this study are shaded gray (modified from Silverman, 1988).

Figure 3: Geographical distribution of all study areas discussed in the text. Exum and Harms' (1968) western area is the marine-bar study while the eastern contains the valley-fill. Graham (2000) completed a more regional sequence stratigraphic look at the J Sandstone.. 6

Figure 4: Stratigraphic section of J Sandstone in Exum and Harms study areas. Figure shows the different J1 sections (modified from Exum and Harms, 1968). 7

Figure 5: Map showing the northwest - southeast upper J1 trend and the northeast - southwest lower J1 trend. Cross-section in Figure 7 depicted across Willson Ranch field (modified from Exum and Harms, 1968).

Figure 6: Cores showing the three interpreted facies within the marine bar setting. Note the interfingering of lithologies (from Exum and Harms, 1968)..

Figure 7: Cross-section across Willson Ranch field depicting the effect interfingering of shale and sandstone has on SP log responses. Lower cross-section exhibits the change in clay content (concentration of fixed negative charges) as calculated from SP and x-ray diffraction of cores. Note clay content decreases (lighter shading) with proximity to reservoir axis. Line of section depicted on Figure 5 (from Exum and Harms, 1968). 10

Figure 8: Block diagram depiction of the ribbon-like valley-fill reservoir. Structural relief is shown on top of the J Sandstone and made visible with east-to-west lines. Oil production is found where northwest-plunging anticlinal noses intersect the valley-fill deposits (from Exum and Harms, 1968). 12

Figure 9: Comparison of reservoir geometries (from Exum and Harms, 1968)......................... 12

Figure 10: Nomenclature of Graham (modified from Graham, 2000)...................................... 14

Figure 11: Graham's first and second depositional systems (from Graham, 2000).................... 14

Figure 12: Graham's third depositional system (from Graham, 2000)...................................... 15

Figure 13: Composite isopach of MS-6 and MS-5 informal members (from Graham, 2000).... 17 
Figure 14: Log showing the transition into the MS-4 informal member (modified from Graham, 2000). 18

Figure 15: Isopach map of MS-3 informal member (from Graham, 2000)............................ 21

Figure 16: Isopach map of MS-2 informal member (from Graham, 2000) ............................ 22

Figure 17: Isopach map of MS-1 informal member (from Graham, 2000) ............................ 23

Figure 18: Generalized geology of the study area. Structural top of the Dakota Group with a 1000' contour interval (from Silverman, 1988). 25

Figure 19: $C_{7}$ hydrocarbon distribution of Denver Basin oils. Oils produced from different Cretaceous-aged reservoirs from throughout the Denver basin are compositionally similar

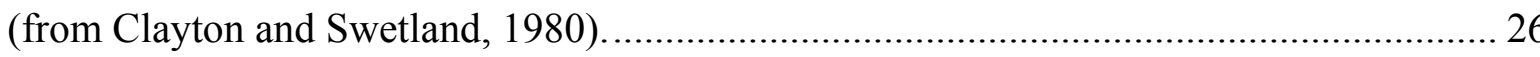

Figure 20: Vitrinite reflectance $\left(\% \mathrm{R}_{0}\right)$ values with their respective gas chromatograms of $\mathrm{C}_{15^{+}}{ }^{+}$ saturated hydrocarbons from selected shales within the Denver basin. Thermally mature shales (samples $20 \& 36$ ) have $\% \mathrm{R}_{\mathrm{o}}$ values ranging from $0.6-1.3$ and a single peak gas chromatogram distribution. Bimodal gas chromatograms (sample $22 \& 32$ ) and lower $\% \mathrm{R}_{\mathrm{o}}$ values $(<0.60)$ reflect thermally immature shales. $\% \mathrm{R}_{\mathrm{o}}$ values from eastern Colorado (sample 32) are representative of southwest Nebraska $\mathrm{R}_{\mathrm{o}}$ values (from Clayton and Swetland, 1980).

Figure 21: Distribution of vitrinite reflectance values of shales throughout the Denver basin. Along the basin axis, thermally mature shales have vitrinite reflectance values ranging from $0.62-0.85 \% \mathrm{R}_{0}$, while the basin flanks (eastern Colorado, western Nebraska) have immature shales below the critical $0.60 \% \mathrm{R}_{\mathrm{o}}$ value (modified from Clayton and Swetland, 1980).

Figure 22: $\mathrm{C}_{7}$ hydrocarbon distributions of shale cuttings and oil samples taken from two wells

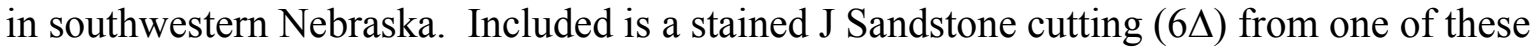
wells. The oil stained $\mathrm{J}$ sample and produced oils from the area are compositionally the same. Note, there is a disconnect between the $\mathrm{J} \&$ oil sample compositions and the shale compositions. Produced oils had to migrate laterally into the area (modified from Clayton and Swetland, 1980)

Figure 23: Map showing the areal extents of 500 data points with well logs. 34

Figure 24: Sample well $\log$ (26157051290000, Section 28 - T21N - R55W, NENE) showing the three picks. 35 
Figure 25: Structural contour map of the top of the J Sandstone. 10 known oil fields are labeled. Note the structural "nosing" that extends across the trend. Contour interval 50 feet. Each section is approximately one square mile in area.

Figure 26: High-resolution structural contour map of Minatare field. Red squares indicate producing wells while blue diamonds show dry holes. Contour interval 5 feet. Each section

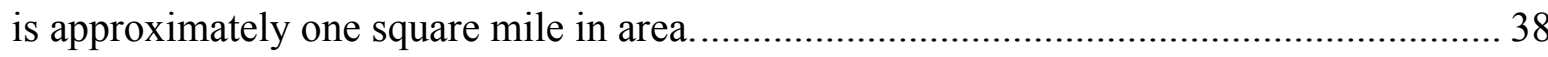

Figure 27: High-resolution structural contour map of Highline and Mustang Canyon field. Red squares indicate producing wells while blue diamonds show dry holes. Contour interval 5 feet. Each section is approximately one square mile in area.

Figure 28: High-resolution structural contour map of Cedar Valley field. Red squares indicate producing wells while blue diamonds show dry holes. Contour interval 5 feet. Each section is approximately one square mile in area.

Figure 29: Second Order Trend map of the J Sandstone structure. Contour interval 50 feet..... 43 Figure 30: Second Order Residual map of the J Sandstone structure. Note the residual high that corresponds to Silverman's trend. Contour interval 10 feet.

Figure 31: Isopach map from the Huntsman Shale marker to the top of the J Sandstone. Contour interval 2 feet.

Figure 32: Isopach map of the J1 net Sandstone - no bias. Although contours obey data points, the isopach lacks depositional grain. Contour interval 2 feet.

Figure 33: Isopach map of the J1 net Sandstone - northeast bias parallel to Exum and Harms' (1968) northeast trend for their lower J1 Sandstone. Contour interval 2 feet..... 51

Figure 34: Isopach map of the J1 net Sandstone - north bias parallel to Exum and Harms' (1968) north trending valley-fill. Contour interval 2 feet......

Figure 35: Highline field showing the northwest trends of the reservoirs. Red squares indicate producing wells while blue diamonds show dry holes.

Figure 36: Isopach map of the J1 net Sandstone - northwest bias parallel to Exum and Harms' (1968) northwest trend for their upper J1 Sandstone. Contour interval 2 feet. 55

Figure 37: Base map showing locations of cross-sections in the study area. 58

Figure 38: Structural cross-section parallel to regional dip across Cedar Valley Field. Each well $\log$ displays a SP, resistivity \& conductivity (left to right) curve. Huntsman Shale marker, J1 Sandstone top and base picks are shown by thin lines with arrow heads. Green boxes 
illustrate net J1 Sandstone thicks and blue line within the J1 interval represents an interpreted oil-water contact, where possible.

Figure 39: Stratigraphic cross-section parallel to regional dip across Cedar Valley Field. Each well $\log$ displays a SP, resistivity \& conductivity (left to right) curve. Huntsman Shale marker, J1 Sandstone top and base picks are shown by thin lines with arrow heads. Green boxes illustrate net J1 Sandstone thicks and blue line within the J1 interval represents an interpreted oil-water contact, where possible.

Figure 40: Structural cross-section parallel to regional strike across Cedar Valley Field. Each well log displays a SP, resistivity \& conductivity (left to right) curve. Huntsman Shale marker, J1 Sandstone top and base picks are shown by thin lines with arrow heads. Green boxes illustrate net J1 Sandstone thicks and blue line within the J1 interval represents an interpreted oil-water contact, where possible.

Figure 41: Stratigraphic cross-section parallel to regional strike across Cedar Valley Field. Each well log displays a SP, resistivity \& conductivity (left to right) curve. Huntsman Shale marker, J1 Sandstone top and base picks are shown by thin lines with arrow heads. Green boxes illustrate net J1 Sandstone thicks and blue line within the J1 interval represents an interpreted oil-water contact, where possible.

Figure 42: Structural cross-section parallel to regional dip across Minatare Field. Each well log displays a SP, resistivity \& conductivity (left to right) curve. Huntsman Shale marker, J1 Sandstone top and base picks are shown by thin lines with arrow heads. Green boxes illustrate net J1 Sandstone thicks and blue line within the J1 interval represents an interpreted oil-water contact, where possible.

Figure 43: Stratigraphic cross-section parallel to regional dip across Minatare Field. Each well $\log$ displays a SP, resistivity \& conductivity (left to right) curve. Huntsman Shale marker, J1 Sandstone top and base picks are shown by thin lines with arrow heads. Green boxes illustrate net J1 Sandstone thicks and blue line within the J1 interval represents an interpreted oil-water contact, where possible. 70

Figure 44: Structural cross-section parallel to regional strike across Minatare Field. Each well $\log$ displays a SP, resistivity \& conductivity (left to right) curve. Huntsman Shale marker, J1 Sandstone top and base picks are shown by thin lines with arrow heads. Green boxes 
illustrate net J1 Sandstone thicks and blue line within the J1 interval represents an interpreted oil-water contact, where possible.

Figure 45: Stratigraphic cross-section parallel to regional strike across Minatare Field. Each well $\log$ displays a SP, resistivity \& conductivity (left to right) curve. Huntsman Shale marker, J1 Sandstone top and base picks are shown by thin lines with arrow heads. Green boxes illustrate net J1 Sandstone thicks and blue line within the J1 interval represents an interpreted oil-water contact, where possible.

Figure 46: Isopach map of the maximum resistivity with all wells. Note that resistivities diminish on the updip side of oil fields. Contour interval 5 feet. 76

Figure 47: Isopach map of the maximum resistivity with non-productive wells only. Contour interval 5 feet. 79

Figure 48: Highline field's net J1 Sandstone without the producers. Contour Interval 1 foot... 81 Figure 49: Isopach map of the maximum resistivity with non-productive wells only (Contour Interval 5 feet). It is overlain by the net J1 Sandstone isopach with geologic bias (Contour interval 2 feet). Circles show prospective areas of exploration.

Figure 50: Isopach map of the maximum resistivity with non-productive wells only (Contour Interval 5 feet). It is overlain by the net J1 Sandstone isopach with geologic bias (Contour interval 2 feet). Circles show prospective areas of exploration and the residual high is outlined in orange. 


\section{LIST OF TABLES}

Page

Table 1: Geological data from the presented cross-sections............................................. 59 


\section{INTRODUCTION}

Petroleum exploration in the northeastern Denver basin has been continual for over 60 years. Lower Cretaceous D \& J sandstone reservoirs are credited with $90 \%$ of the Denver basin's oil and gas production (Clayton and Swetland, 1980). Today's high energy prices, coupled with our ever-declining known reserves, make the mature Denver basin an ideal candidate to reevaluate its petroleum potential. Many times we think that all discoveries have been found in an area, only to later discover that, with a little innovation, there are still untapped reserves (Blakey, 1985).

The main focus of this study is to reexamine the Scotts Bluff Trend for potential reserves and reservoirs (Silverman, 1988). This study is centered on Scotts Bluff County, Nebraska and the western limits of Morrill County (Figure 1). Located here are 10 oil fields that produce from the Cretaceous $\mathrm{J1}$ Sandstone. These fields are aligned along a N60 $\mathrm{E}$ trend that Silverman (1988) termed the Scotts Bluff Trend. The trend spans the following townships and ranges: T21 - 23N \& R52 - 56W.

In order to revisit Scotts Bluff Trend's potential; a three-fold program is followed. First, the identification of any structural controls on the trend is assessed. Silverman (1988) suggested that oil accumulation is restricted to this trend, because of recurrent movement during the Laramide Orogeny on older Paleozoic basement faults (Tweto, 1980). Determination of structural controls will lead to lower risk in exploration.

The second focus is to document the size and geometry of the J1 Sandstone reservoirs within the Scotts Bluff Trend. This focus also will aid in reducing risk during future hydrocarbon exploration. Understanding the size and geometry of the reservoirs will further assist in understanding the depositional environment of the J1 Sandstone. 
Lastly, this research tries to establish a predictor of hydrocarbons based on current knowledge of electrical resistivities, for the study area. With large portions of the study area sparsely drilled, knowledge of where oil is possibly situated, coupled with other potential reservoirs, can lead to additional major fields of interest.

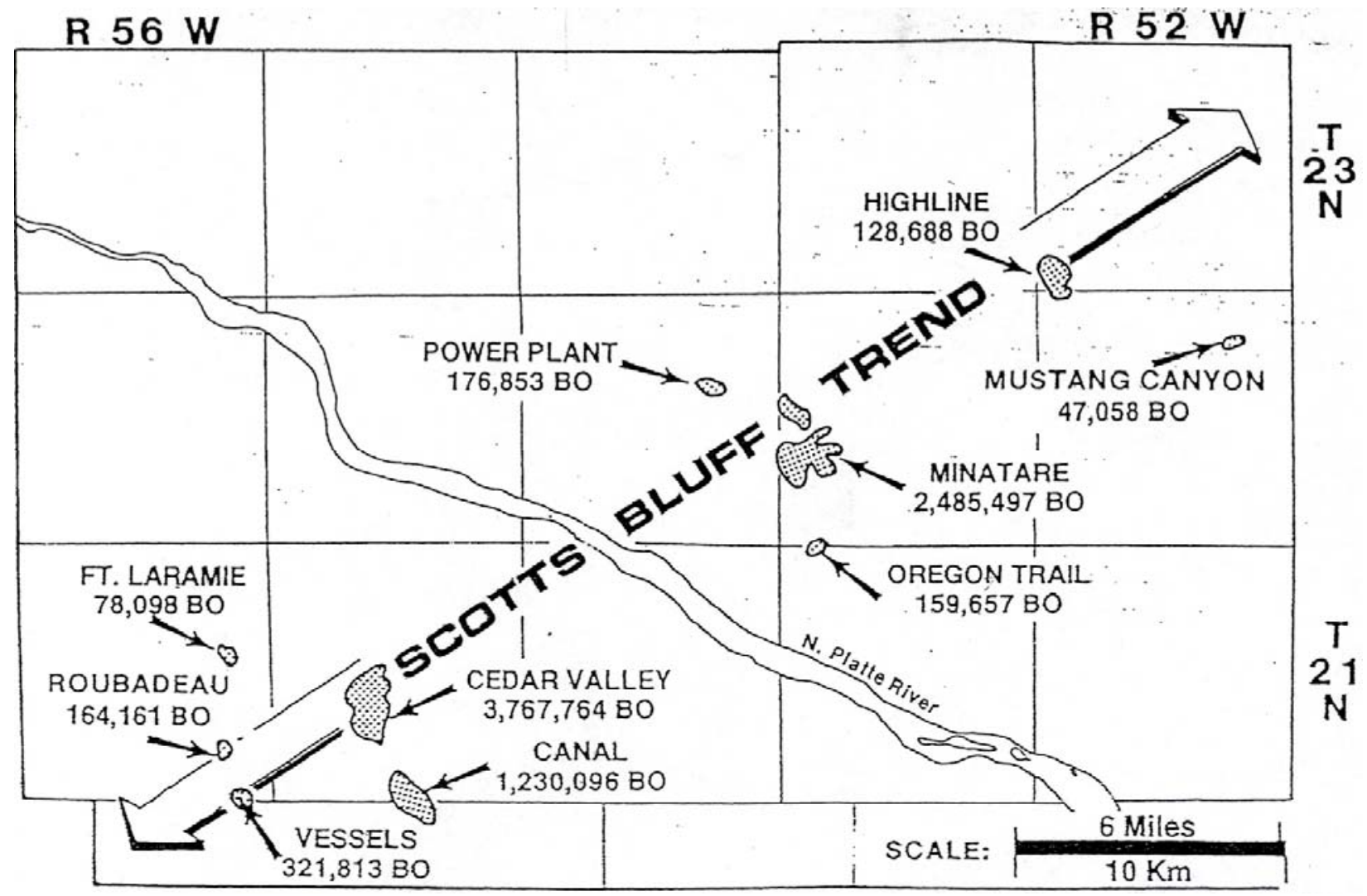

Figure 1: Map showing the 10 oil fields that comprise the Scotts Bluff Trend. Shown for each field is the production through 1987 (from Silverman, 1988). 


\section{STRATIGRAPHY}

The $\mathrm{J}$ Sandstone is part of the Lower Cretaceous Dakota Group (Figure 2). Although there are different stratigraphic nomenclatures for the group (Sonnenberg \& Weimer, 1981; Silverman, 1988; Graham, 2000), the following description follows that of Silverman (1988). The Dakota Group is comprised of four sandstones, three of which are reservoirs, and two shale units, which are both potential source beds. From the oldest to the youngest these are: Lakota Sandstone, Plainview Sandstone, Skull Creek Shale, J Sandstone, Huntsman-Mowry Shale, and D Sandstone. The Plainview is the only non-reservoir sandstone in the Dakota Group.

Sedimentation during the Early Cretaceous was the result of cyclic transgression and regression of the Western Interior seaway (Silverman, 1988). The J Sandstone was deposited near the middle of this sequence (Clark, 1978). As this sea transgressed southward, the Skull Creek Shale was deposited. When the sea regressed to the north, the $\mathrm{J}$ Sandstone was deposited in shallow-marine environments. Transgressive sediments of the Huntsman-Mowry Shale then covered this sandstone. The group was complete with deposition of the D Sandstone during a final regression of the Dakota Group in the Western Interior seaway (Silverman, 1988).

\section{WESTERN NEBRASKA}

The $\mathrm{J}$ Sandstone in the study area of western Nebraska can be divided into three units from top to base: $\mathrm{J} 1, \mathrm{~J} 2$, and $\mathrm{J} 3$. The $\mathrm{J} 1$ and $\mathrm{J} 2$ sandstones are productive units in the area (mostly $\mathrm{J} 1$ ), whereas the $\mathrm{J} 3$ is productive elsewhere in the basin. The $\mathrm{J} 1$ 
ranges from $0-40$ feet $(0-12.2 \mathrm{~m})$ thick, and the average oil pay is $10-12$ feet $(3-$ $3.7 \mathrm{~m})$ thick. The $\mathrm{J} 2$ is around 40 feet $(12.2 \mathrm{~m})$ thick, and the average oil pay is 8 feet (2.4 m)(Silverman, 1988).

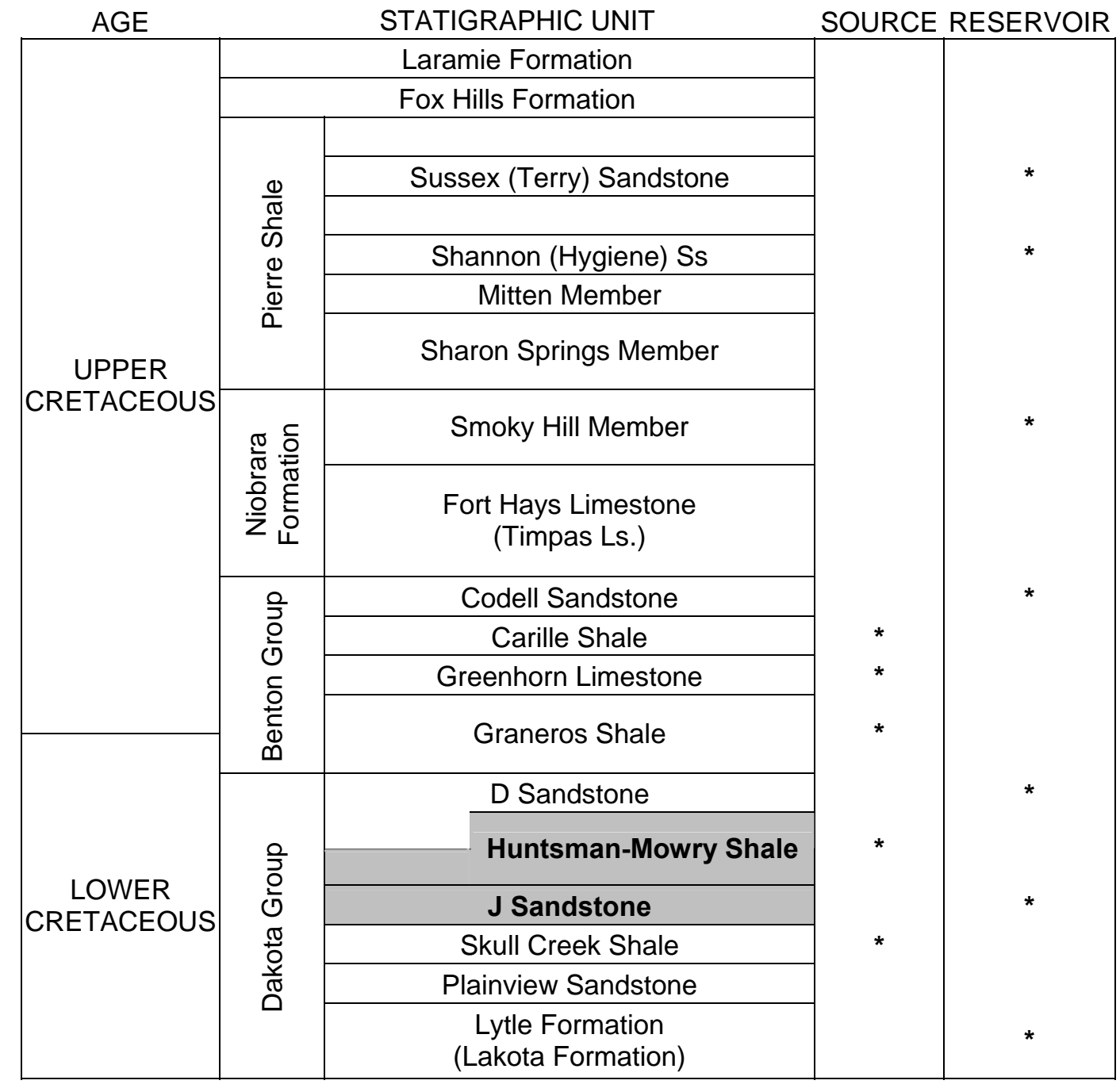

Figure 2: Stratigraphic column of the Denver basin. Targeted formations in this study are shaded gray (modified from Silverman, 1988). 
Exum and Harms (1968) conducted a study on J1 reservoirs in eastern Banner County, western Morrill and Cheyenne Counties, Nebraska (Figure 3). The majority of their study was analysis of the J1 Sandstone centered on the Willson Ranch field in eastern Banner County (marine-bar). This investigation was then compared to work previously done by Harms in 1966 (valley-fill). The marine bars are located in a 72square-mile (18,000 hectares) area southeast of the Scotts Bluff Trend. Here they used 20 cores and 270 geophysical logs to make interpretations about the geometry of the reservoirs and their depositional environment. Figure 4 depicts how they divided the $\mathrm{J} 1$ Sandstone into different mappable intervals and its comparison to the valley-fill J1 reservoir (Exum and Harms, 1968).

The two stratigraphic intervals of the J1 Sandstone are lenticular sand bodies with a maximum thickness of approximately 25 feet $(7.6 \mathrm{~m})$ (Figure 5). In map view they are about 0.3 to 1.5 miles $(0.5-2.4 \mathrm{~km})$ wide by 1.5 to 5 miles $(2.4-8.1 \mathrm{~km})$ in length. The axis of the upper $\mathrm{J} 1$ bars is oriented in a northwest direction, while the lower $\mathrm{J} 1$ bars are normal to these in a northeast direction. Laterally these bars interfinger into shale or siltstone, suggesting that at the time of deposition these bars were bathometric highs on the sea floor (Exum and Harms, 1968).

Figure 6 shows three cores that represent the facies that comprise these marine bars. These cores illustrate the character of the marine bars and their lateral transition into shale. On the left is a core representing the central-bar facies. This facies is a finegrained sandstone with very few shale partings and low-angle cross-bedding. The main reservoirs in the study area are comprised of the central-bar facies (Exum and Harms, 1968). 


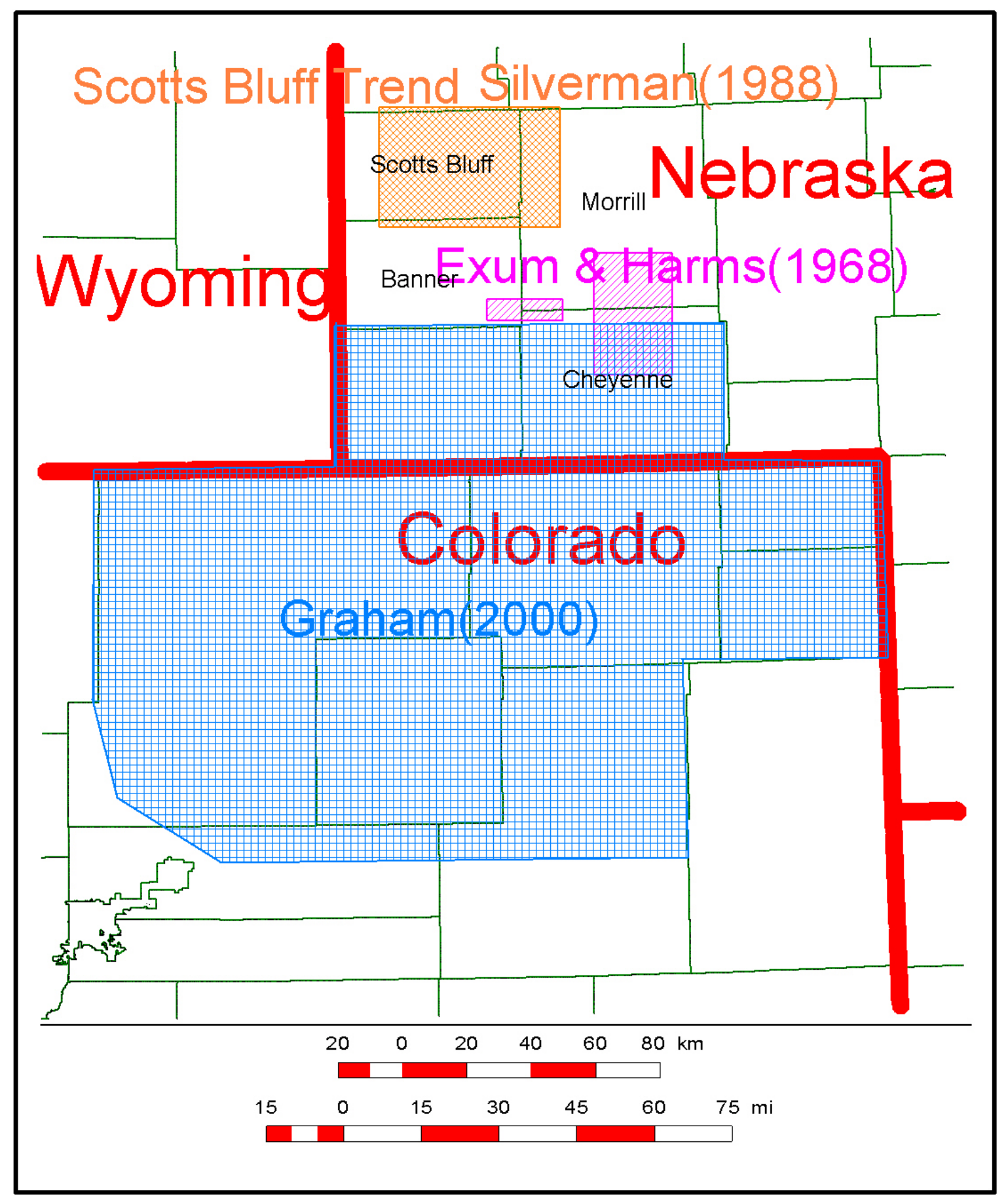

Figure 3: Geographical distribution of all study areas discussed in the text. Exum and Harms' (1968) western area is the marine-bar study while the eastern contains the valley-fill. Graham (2000) completed a more regional sequence stratigraphic look at the J Sandstone. 


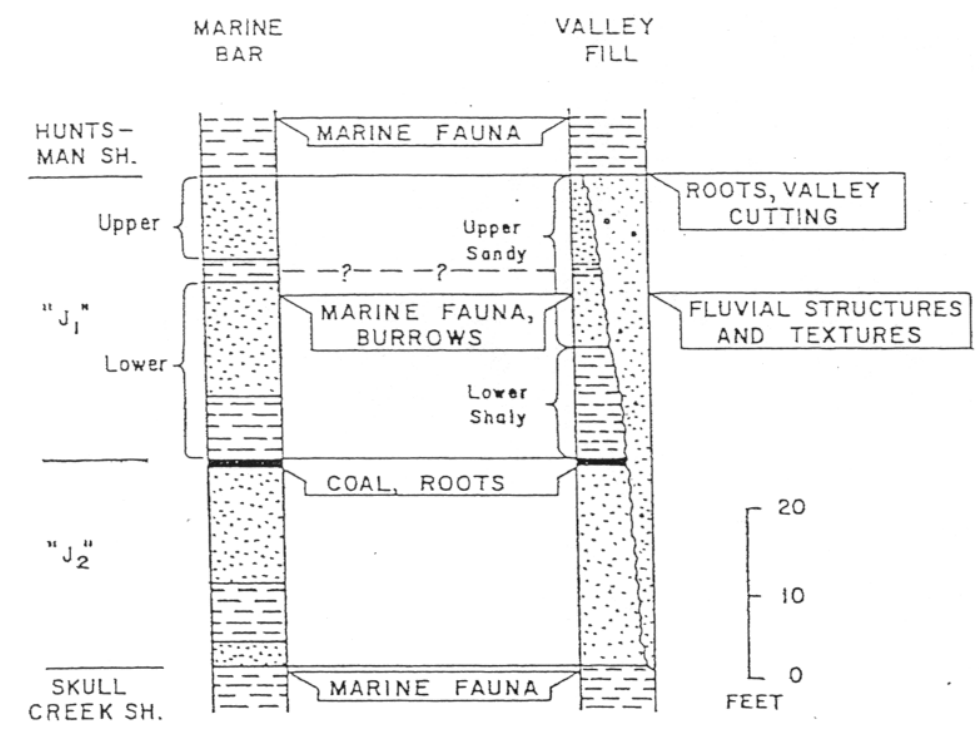

Figure 4: Stratigraphic section of J Sandstone in Exum and Harms study areas. Figure shows the different J1 sections (modified from Exum and Harms, 1968).

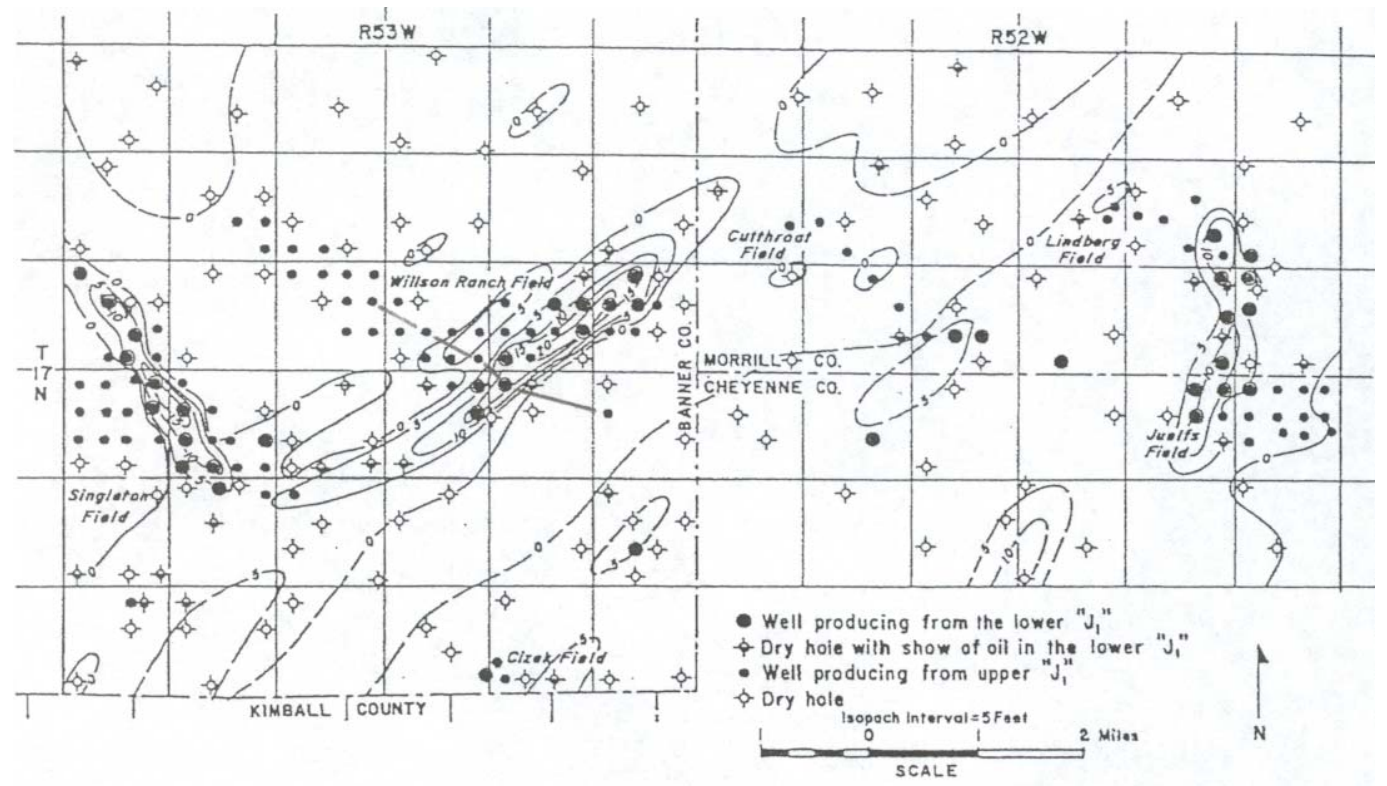

Figure 5: Map showing the northwest - southeast upper J1 trend and the northeast - southwest lower J1 trend. Cross-section in Figure 7 depicted across Willson Ranch field (modified from Exum and Harms, 1968). 

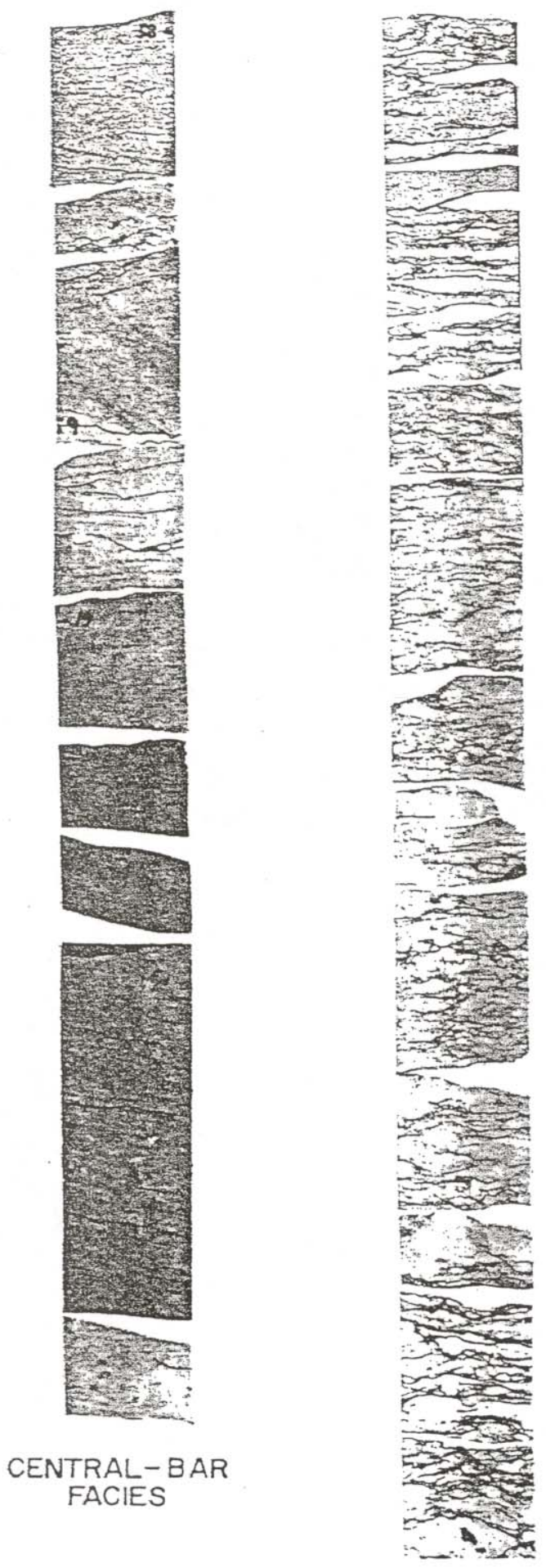

BAR-MARGIN



INTER-BAR FACIES

FACIES

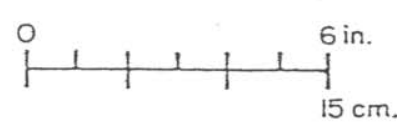

Figure 6: Cores showing the three interpreted facies within the marine bar setting. Note the interfingering of lithologies (from Exum and Harms, 1968). 
The bar-margin facies lies in the middle of Figure 6 . This facies is comprised of a mottled mixture of fine-grained sandstone and shale. Sedimentary structures are indistinguishable due to the amount of burrowing that has occurred after deposition. The sandstone pods found throughout this facies are similar in composition to the sandstone of the central-bar facies. The bar-margin facies areally surrounds the central-bar facies. Typically this facies contains approximately $5-10$ feet $(1.5-3 \mathrm{~m})$ of net sandstone within the interval (Exum and Harms, 1968).

On the right of Figure 6 is a core of the inter-bar facies. Compositionally, these rocks consist mostly of shale. Thin layers of sandstone are present which, like the barmargin facies, is texturally identical to the main reservoir central-bar facies. This outer most facies is typical of the non-productive rock that encases the reservoirs (Exum and Harms, 1968).

This interfingering of facies can also be seen on electric logs. Figure 7 depicts a cross-section, shown on Figure 5, in a northwest to southeast direction across the Willson Ranch field. The upper cross-section shows how the SP and resistivity signatures, of the lower J1 Sandstone, progressively change from shale to sandstone and then back to shale across the field. Accompanying this cross-section is a depiction of how the clay content (concentration of fixed negative charges) changes with the log patterns. Clay content was determined by x-ray diffraction on the available cores and decreases (lighter shading) with proximity to the reservoir axis (Exum and Harms, 1968).

The study of valley-fill sandstone was conducted approximately 20 miles (32 km) east of its marine-bar counterpart in southern Morrill and northern Cheyenne Counties, 


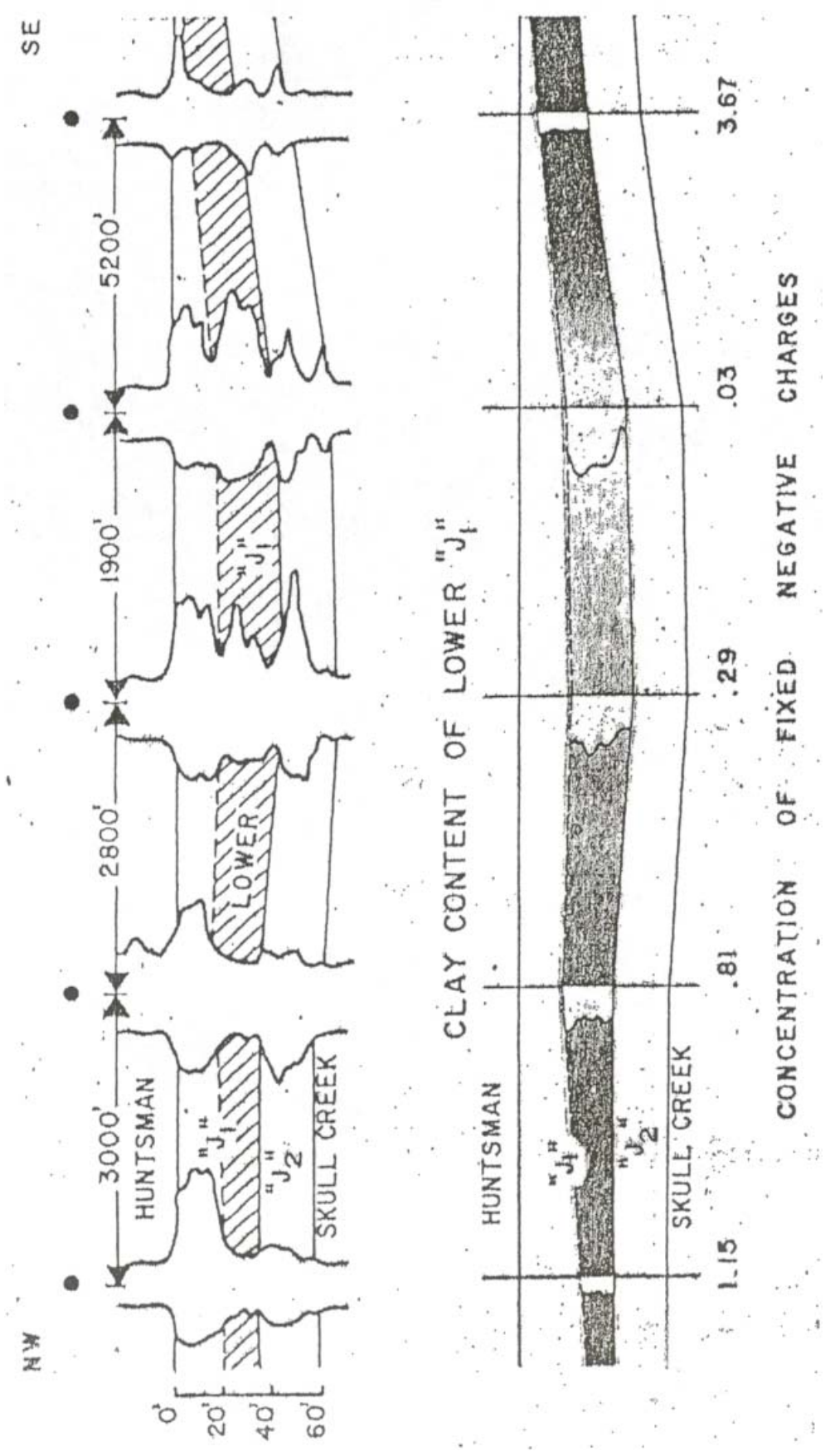

Figure 7: Cross-section across Willson Ranch field depicting the effect interfingering of shale and sandstone has on SP log responses. Lower crosssection exhibits the change in clay content (concentration of fixed negative charges) as calculated from SP and x-ray diffraction of cores. Note clay content decreases (lighter shading) with proximity to reservoir axis. Line of section depicted on Figure 5 (from Exum and Harms, 1968). 
Nebraska (Figure 3). Here, marine bars of the $\mathrm{J} 1$ and $\mathrm{J} 2$ Sandstones are relatively thin which make them unsuitable as producing reservoirs. Instead, after deposition, these marine bar deposits were aerially exposed, eroded, and replaced by stream deposits. Some sedimentary structures of the valley-fill deposits include: siderite nodules, smalland large- scale cross-bedding, current-laid ripple marks, and soft-sediment deformation.

Figure 8 is an isometric block diagram representing the deposition of this stream deposit in the $\mathrm{J}$ Sandstone. This north-to-south valley-fill measures 20 miles (32 km) long and 2,000 feet $(610 \mathrm{~m})$ wide. The fluvial sandstone ranges in thickness from $40-$ 80 feet $(12-24 \mathrm{~m})$. Lateral boundaries, unlike the marine-bar area to the west, are abrupt and erosional (Exum and Harms, 1968).

Figure 9 summarizes the differences in these two reservoirs (Exum and Harms, 1968). Of notable difference is the areal extent of each facies. In map view, the marine bars are wide and short compared to the thin and long valley-fill reservoirs. The channel shape of the valley-fill deposits is more conducive for exploratory prediction, whereas there is no extrapolative nature to the marine bar lenses. Lastly, and most importantly, the nature of the lateral and basal contacts of the two facies creates differing and distinct facies assemblages and different log responses (Exum and Harms, 1968). 


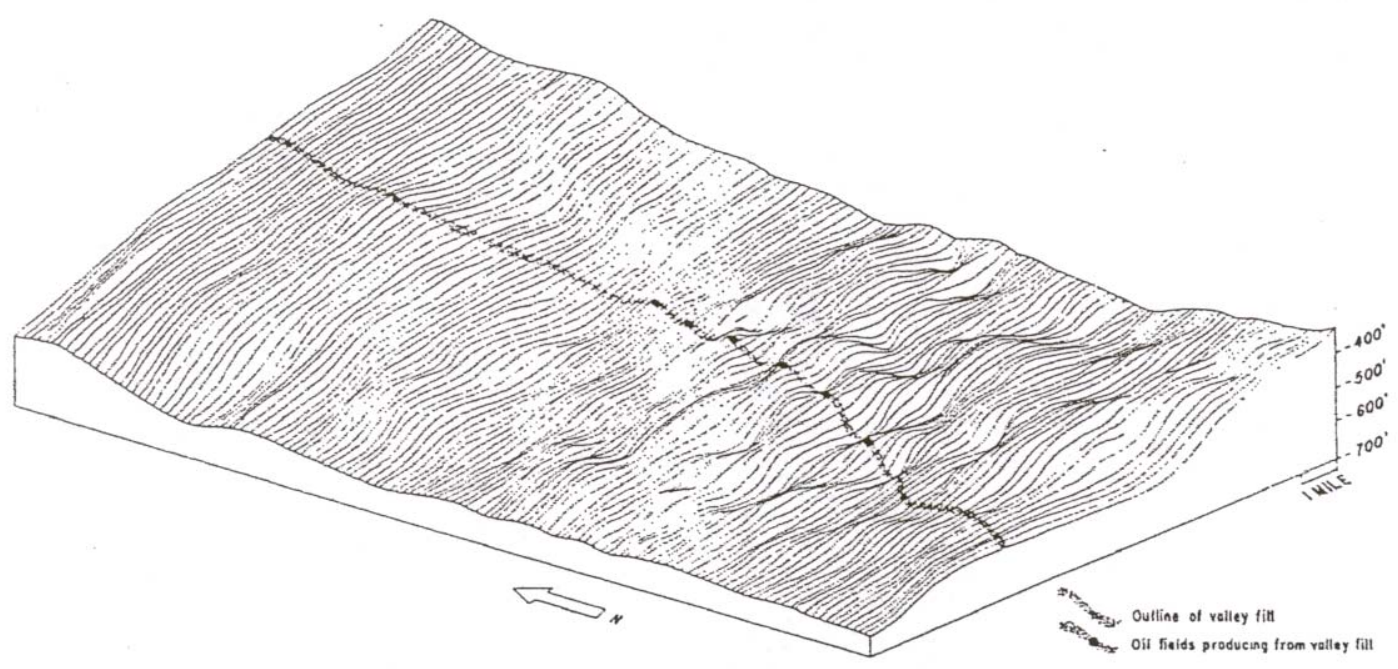

Figure 8: Block diagram depiction of the ribbon-like valley-fill reservoir. Structural relief is shown on top of the $\mathrm{J}$ Sandstone and made visible with eastto-west lines. Oil production is found where northwest-plunging anticlinal noses intersect the valley-fill deposits (from Exum and Harms, 1968).

\section{RESERVOIR GEOMETRY}

\begin{tabular}{lll} 
& \multicolumn{1}{c}{ MARINE BAR } & VALLEY FILL \\
WIDTH & $-0.5-1.5$ MILES & $\sim 0.3-0.4$ MILES \\
LENGTH & $<6$ MILES & $>20$ MILES \\
$\frac{\text { THICXNESS }}{\text { FORM }}$ & $\frac{25 \text { FEET MAXIMUM }}{\text { SCATTERED ELLIPTICAL }}$ & $\begin{array}{c}\text { SINGLE LONG } \\
\text { PENISM }\end{array}$ \\
$\begin{array}{c}\text { LATERAL } \\
\text { CHANGE }\end{array}$ & $\begin{array}{c}\text { DEPOSITIONAL, } \\
\text { GRADATIONAL }\end{array}$ & EROSIONAL, ABRUPT \\
$\begin{array}{c}\text { BASAL } \\
\text { CONTACT }\end{array}$ & $\begin{array}{c}\text { TRANSITIONAL OR } \\
\text { SHARP }\end{array}$ & EROSIONAL
\end{tabular}

Figure 9: Comparison of reservoir geometries (from Exum and Harms, 1968). 


\section{NORTHERN COLORADO}

Graham (2000) studied the J Sandstone in northern Colorado. Figure 3 depicts a map of the area that encompasses Graham's (2000) work in relation to the study areas of Exum and Harms (1968) and this paper. Over time, operators in the basin developed a generic naming system of the different J Sandstone intervals (Graham, 2000). As with any newly developed area, naming occurs as drillers penetrate the intervals. Thus, the first sandstone in the sandstone package below the D Sandstone is labeled the J1, the second is the $\mathrm{J} 2$ and the third is the $\mathrm{J} 3$. The problem of this nomenclature is that it fails to consider unconformities and lateral facies changes. Thus rocks placed in the same interval may not be time synchronous. Unfortunately, this terminology has continued for 60 years.

Understanding the inconsistencies in J Sandstone terminology, Graham presented his own nomenclature as shown in Figure 10. Here the J Sandstone is divided into six informal members, MS-1 - MS-6. Also shown are the associated formal names and drilling terminology from both Colorado and western Nebraska. By applying sequence stratigraphic principles, Graham (2000) was able to differentiate between his informal members and place them into regional depositional systems. Once in these systems, specific environments were recognized (Graham, 2000).

Figures 11 and 12 are schematic diagrams of the three regional depositional systems interpreted by Graham (2000). Depositional system 1 (DS-1) incorporates the J Sandstone informal members: MS-5 and MS-6. The MS-4 informal member is the lone interval that comprises the second depositional system (DS-2). Lastly, depositional 


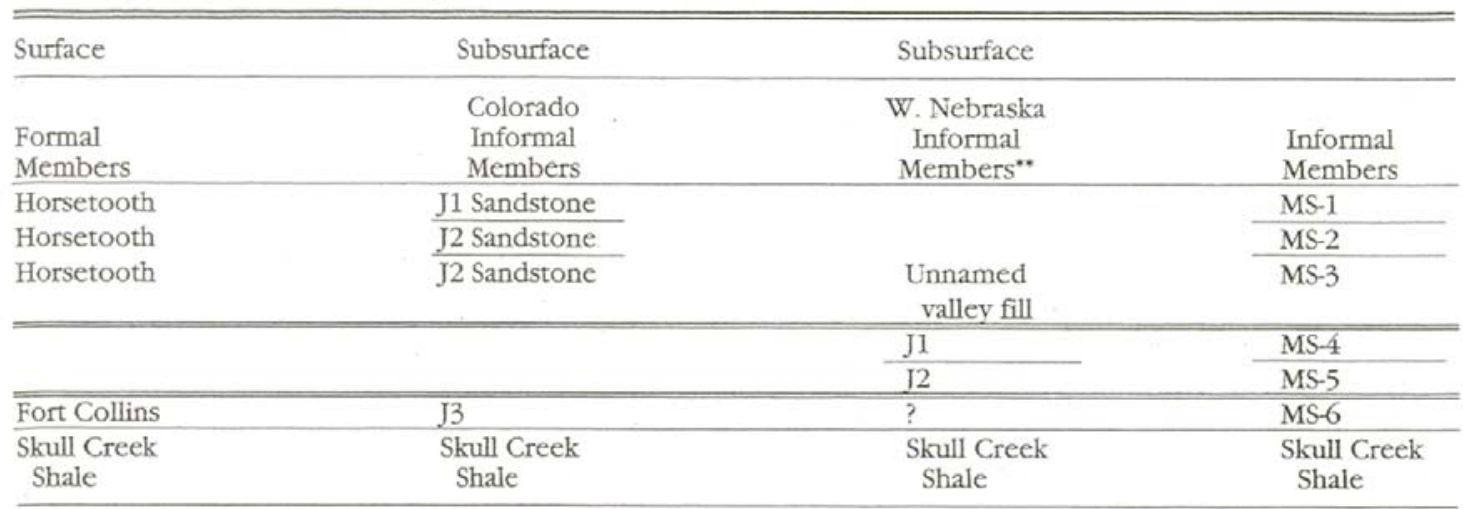

Figure 10: Nomenclature of Graham (modified from Graham, 2000).
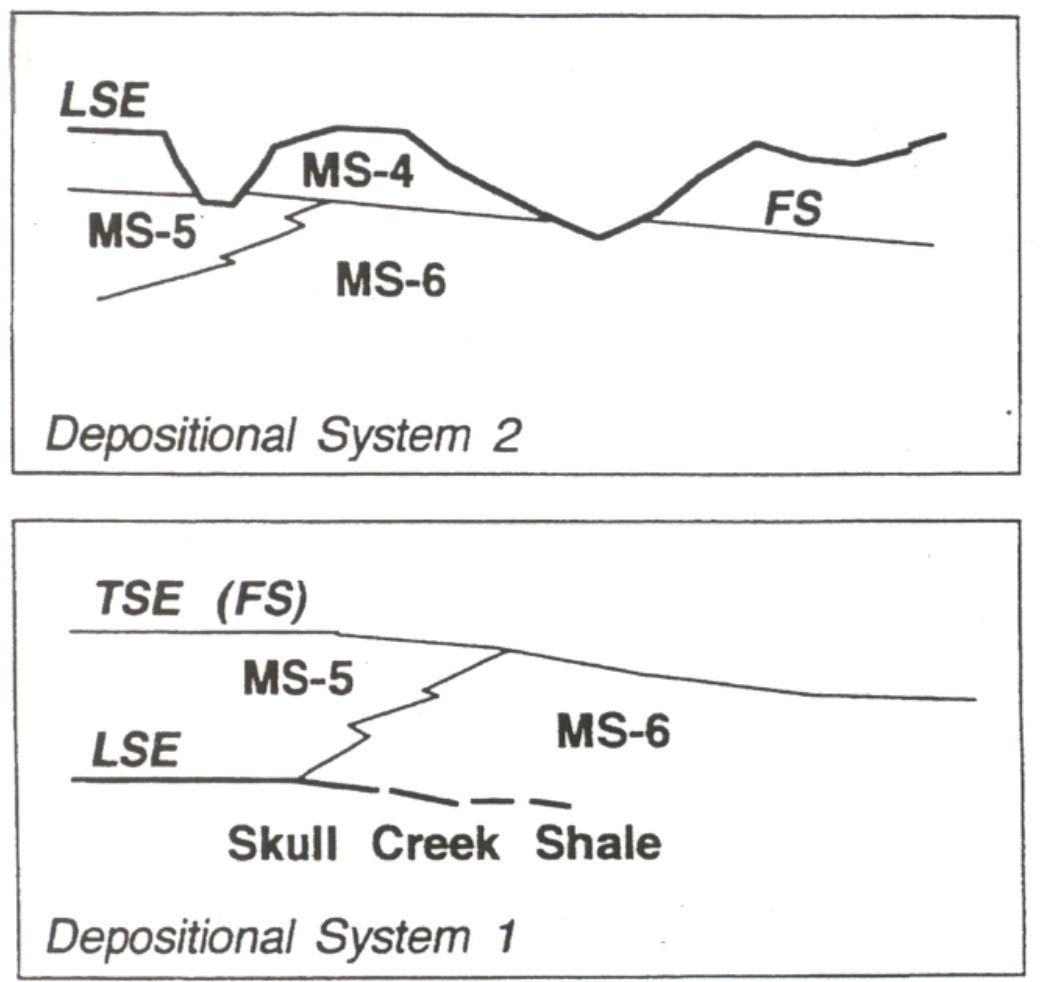

Figure 11: Graham's first and second depositional systems (from Graham, 2000). 

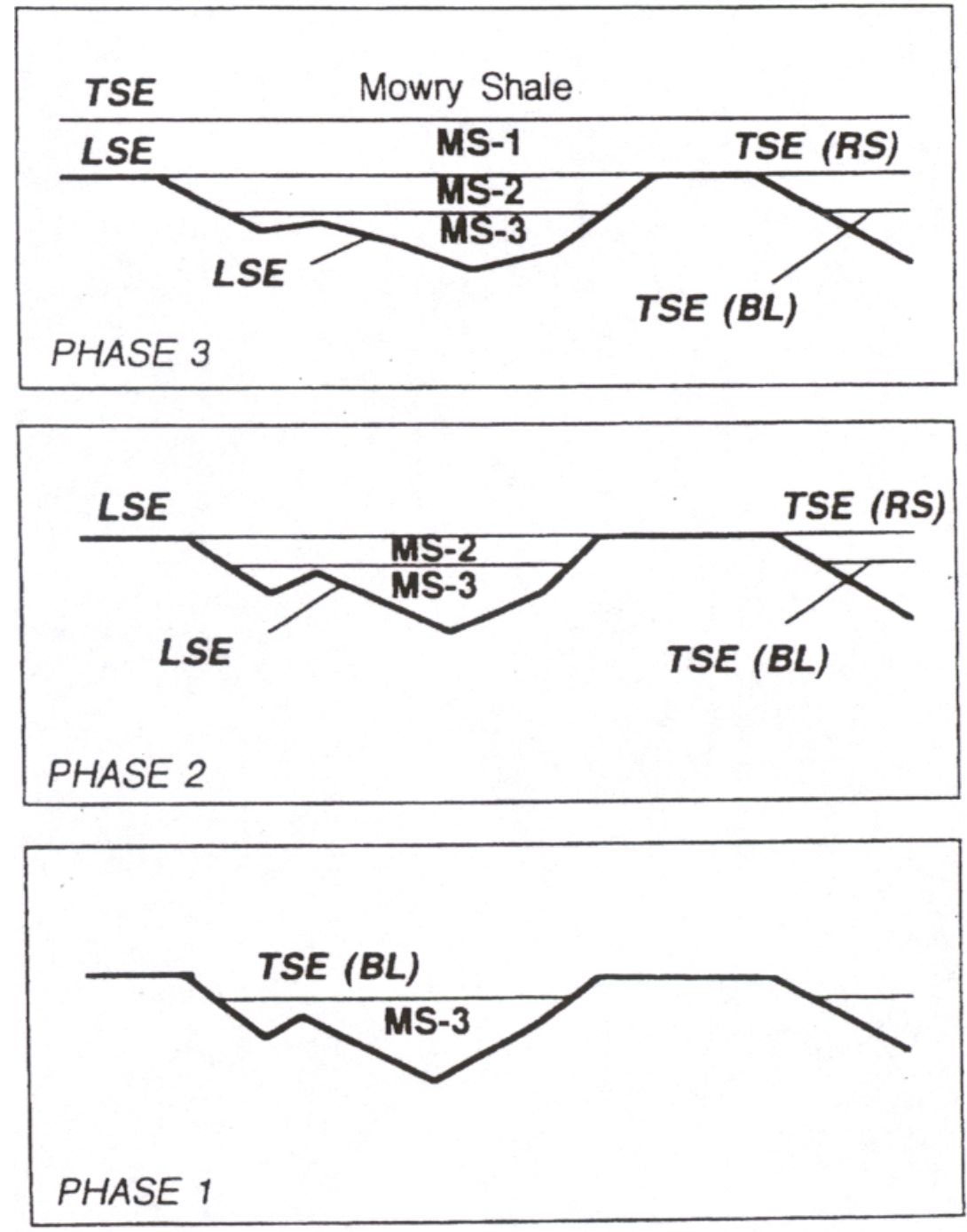

\section{DEPOSITIONAL SYSTEM 3}

Figure 12: Graham's third depositional system (from Graham, 2000). 
system 3 (DS-3) is broken down into three phases in which the MS-3, MS-2 and MS-1 informal units were deposited separately (Graham, 2000).

DS-1 (Figure 11) marks the deposition of sediments during a relative drop in sea level, after deposition of the marine Skull Creek Shale. The base of this system is marked by a lowstand surface of erosion (LSE) and is capped by a flooding surface (FS) or transgressive surface of erosion (TSE). Included in this depositional system (DS-1) are the informal members MS-5 and MS-6 (Graham, 2000).

Graham's (2000) MS-6 marks the change from a deep-marine environment (Skull Creek Shale) into a shallow-marine environment. The principle evidence of this is the vertical transition from Cruziana to Skolithos ichnofacies. Cruziana are indicative of low to moderate energy settings like that of a subtidal environment, whereas the Skolithos thrive in high flow regimes like that of a shoreface setting. The MS-6 geometry (Figure 13) suggests that this unit is a wave-dominated delta (Graham, 2000).

The top of the MS- 6 is marked by a sudden termination of bioturbation and a distinct textural change to relatively coarser grained sandstones in the MS-5 interval. The MS-5 interval of Graham's nomenclature is correlative with the J2 member of Nebraska (Figure 10).

As seas regressed and accommodation space diminished, the MS-5 sandstones began prograding seaward, producing elongate northeast - southwest trending lobes. Graham (2000) interpreted this interval as an accumulation of lowstand sandstone bars that stacked on top of the previously deposited wave-dominated delta (Graham, 2000).

Both the MS-5 and MS-6 are sharply overlain by MS-4 interval (Figure 14). This sharp break is the TSE of FS that marks the upper boundary of the DS-1 and the base 


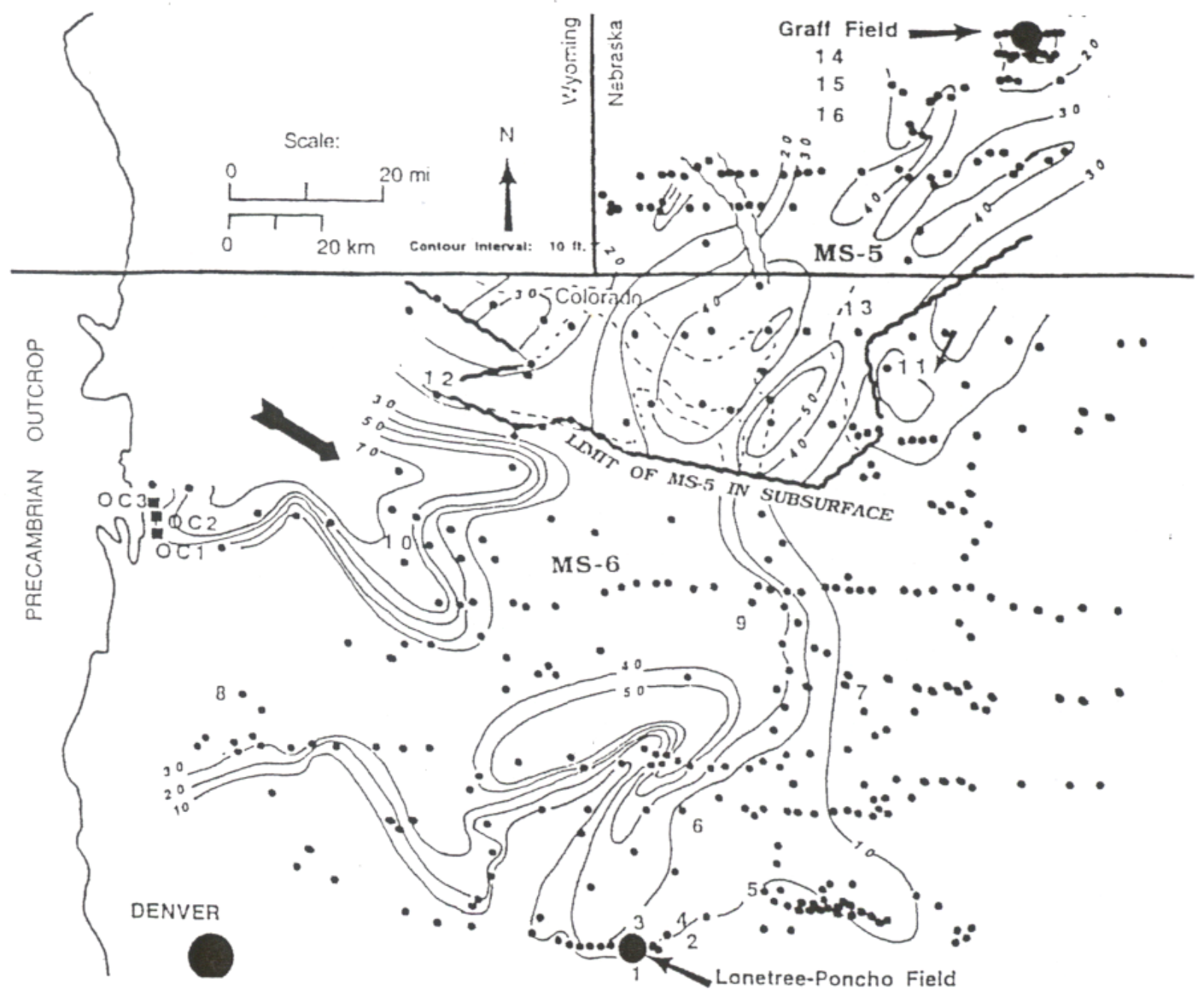

Figure 13: Composite isopach of MS-6 and MS-5 informal members (from Graham, 2000). 


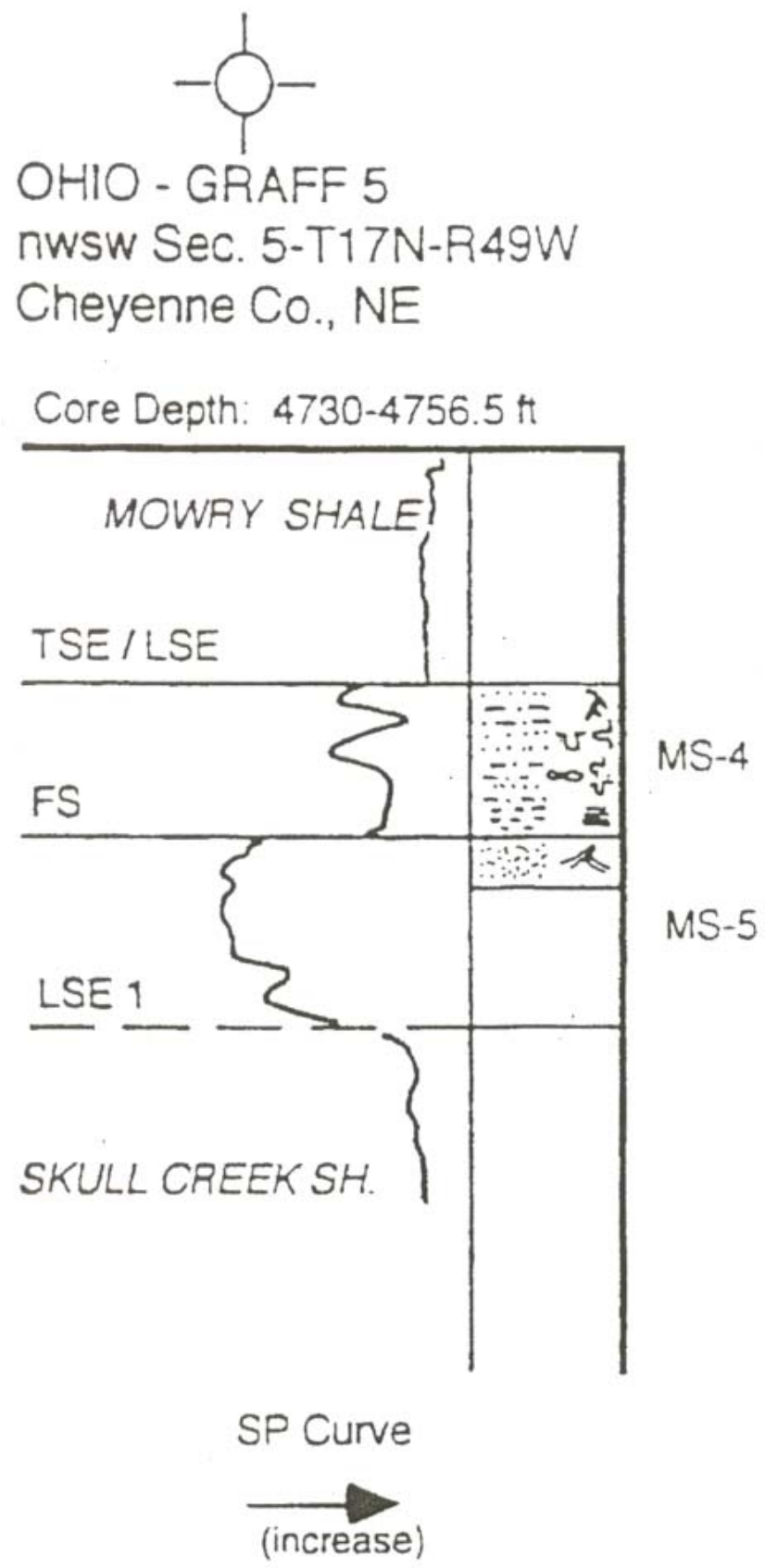

Figure 14: Log showing the transition into the MS-4 informal member (modified from Graham, 2000). 
of the DS-2 (Figure 11). Of special note is that the upper bounding LSE for DS-2 has in some places eroded away this FS (Graham, 2000).

Texturally the MS-4 interval coarsens upward with the basal part being composed of fissile shales. These shales mark an abrupt change with the underlying formations and are interpreted to be a result of a rise in relative sea level. Capping the unit are root casts and plant debris, which indicates subaerial exposure and thus another regression. The sandstones within this unit are too thin regionally to map (Graham, 2000).

The MS-4 informal member corresponds with both of Exum and Harms' (1968) J1 Sandstone intervals in western Nebraska and the J1 Sandstone mapped by the author later in this paper. This facies contains swamp-derived pollen and arenaceous foraminifera, which point toward an environment that is open-marine (Graham, 2000).

The DS-3 (Figure 12) of Graham (2000) is bounded at its base by the same LSE that caps the DS-2. In some locales this LSE has eroded down into both of the lower depositional systems (MS-5, MS-6, MS-4). Over time this LSE was covered with fluvial sediments (MS-3), much like the incised valleys of Exum and Harms (1968), as the sea began to rise (Figure 15). A bayline surface (BL) is what differentiates phase 1 and phase 2. The $B L$ is defined as the change from non-marine to marine deposition. As the sea transgressed over the area, sediments (MS-2) were reworked and topped by a ravinement surface (RS). The MS-2 (Figure 16) is interpreted to be an estuary that has backfilled over the incised valleys of MS-3. Ultimately another sequence of sand (MS-1) was deposited before a transgressive surface of erosion (TSE) capped the system. Figure 17 shows elongate sandstone pods of the MS-1 in a northeast to southwest 
orientation. These are interpreted to be marine bars indicative of a nearshore deposit. Eventually, these sands were completely buried by the encroaching seaway and covered by the marine Mowry Shale and its equivalents (Graham, 2000). 


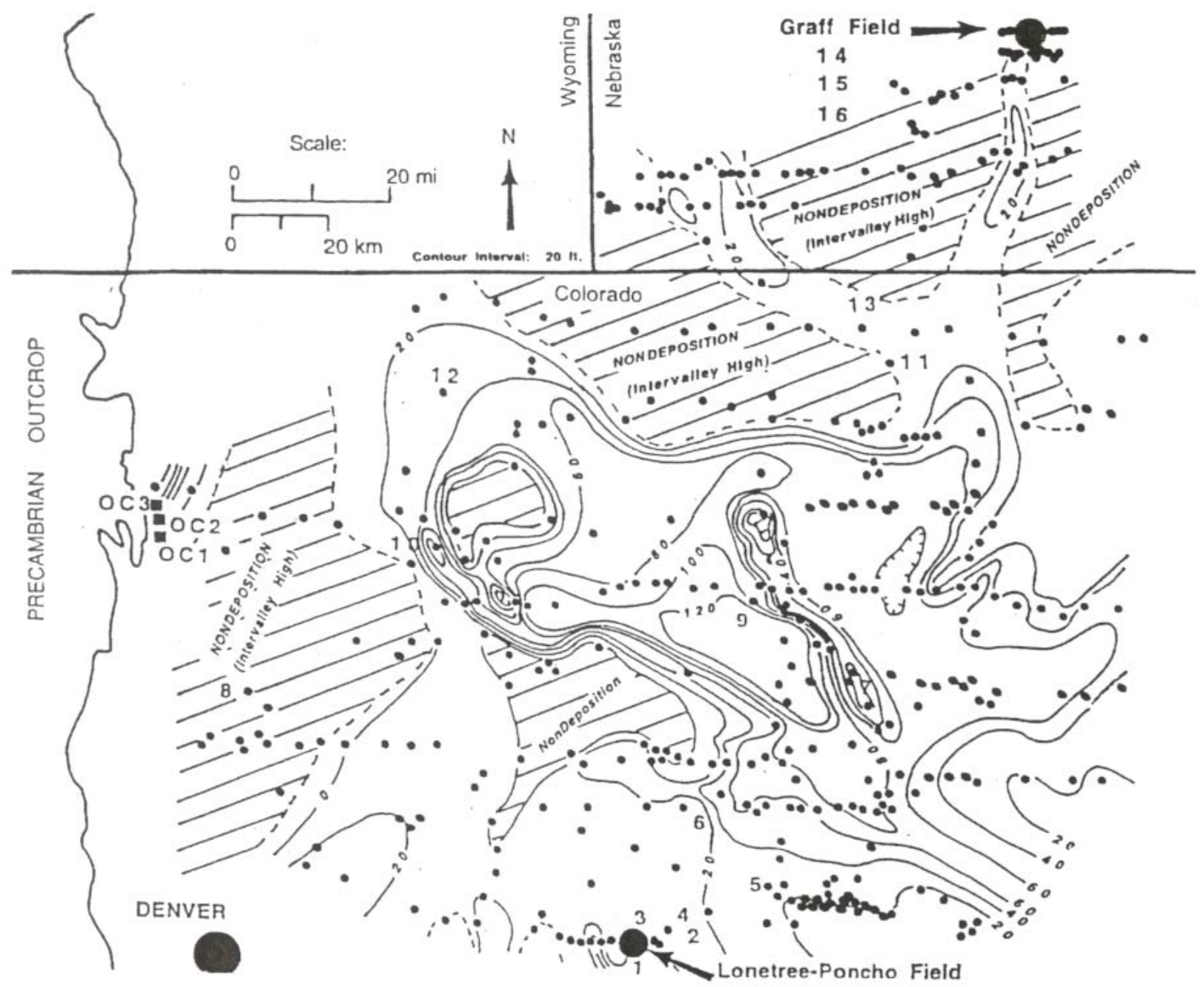

Figure 15: Isopach map of MS-3 informal member (from Graham, 2000). 


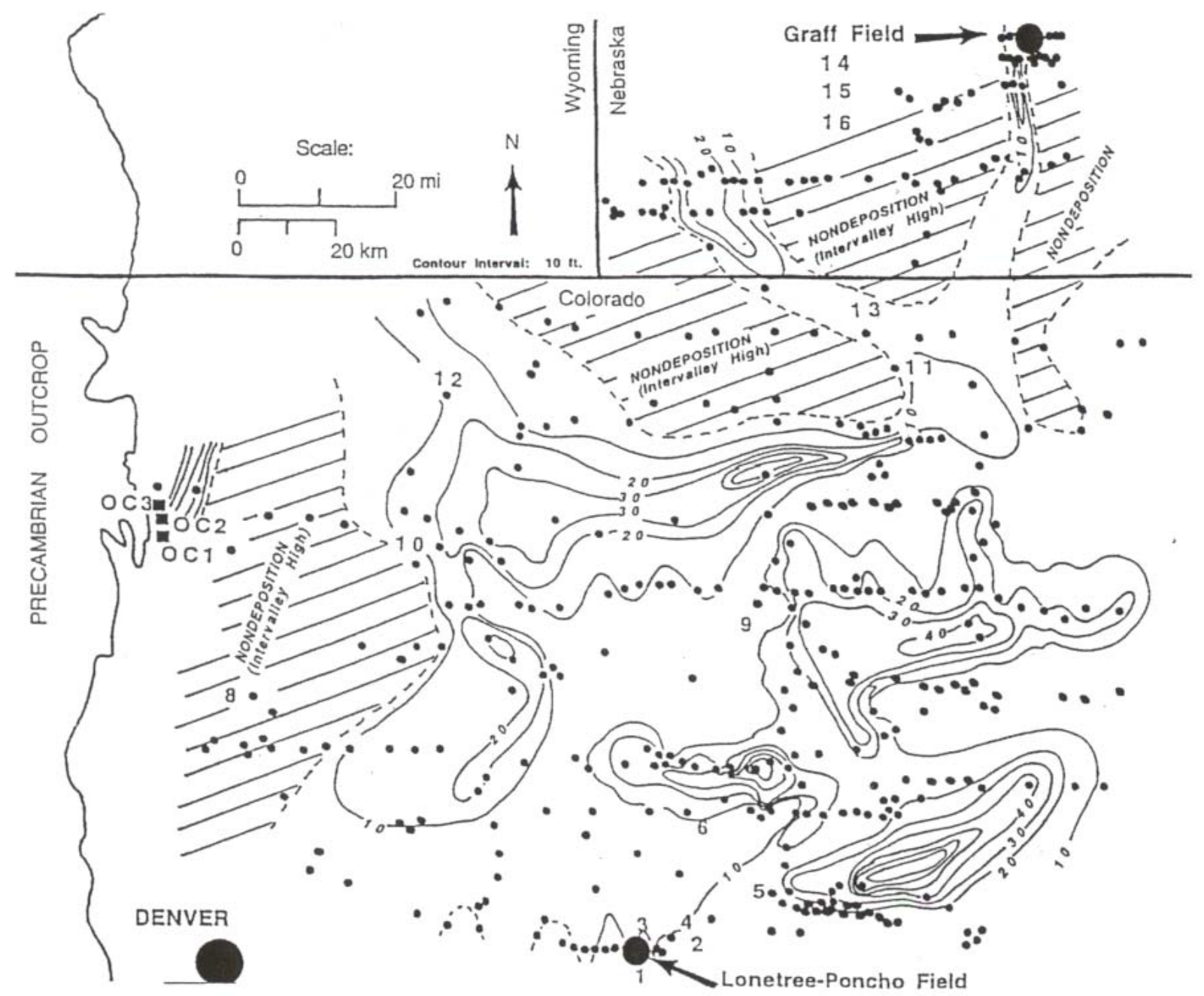

Figure 16: Isopach map of MS-2 informal member (from Graham, 2000). 


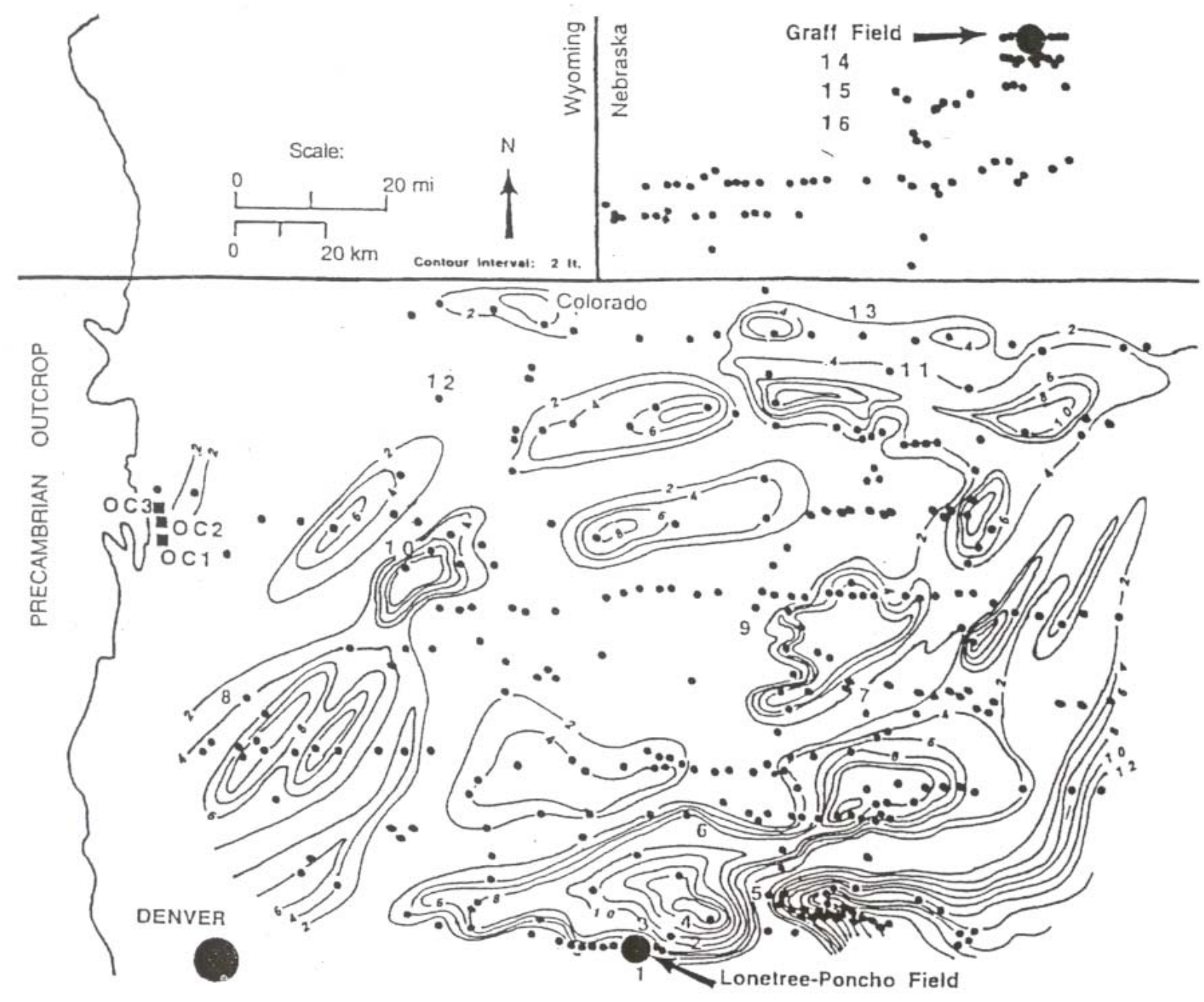

Figure 17: Isopach map of MS-1 informal member (from Graham, 2000). 


\section{OIL MATURATION AND MIGRATION}

The western panhandle of Nebraska marks the northeastern extent of the Denver basin (Figure 18). The Late Cretaceous to Tertiary Laramide Orogeny created most of the present-day features of the Denver basin. Deformation was basement-involved thrust faulting caused by a low-angle subduction zone in the western United States. Faulting and uplift of the Laramide occurred along older Paleozoic faults and uplifts (Tweto, 1980). Recurrent movement along these older faults is thought to be the pathway for hydrocarbon migration into the study area (Silverman, 1980). Knowledge of

where hydrocarbons originate and their subsequent migration is helpful in focusing future exploration along these pathways.

Clayton and Swetland (1980) conducted a hydrocarbon study on Denver basin oils and source beds. This was a three-fold study in which they looked at the geochemistry of produced oils throughout the basin, performed vitrinite reflectance evaluations on potential source beds and correlated the two (Clayton and Swetland, 1980).

Figure 19 depicts the $\mathrm{C}_{7}$ hydrocarbon distribution of 77 oil samples from the Denver basin. The samples are categorized based on their molecular structures and plotted in a triangle, much like that of a sediment composition ternary diagram. Of special note is that all of the Cretaceous oils plot within the same area. This shows that all oils produced from Cretaceous-aged reservoirs are of the same origin (Clayton and Swetland, 1980).

Assessment of potential source rocks was completed with the use of 68 shale samples from throughout the Denver basin. The shales of interest are all Cretaceous in 


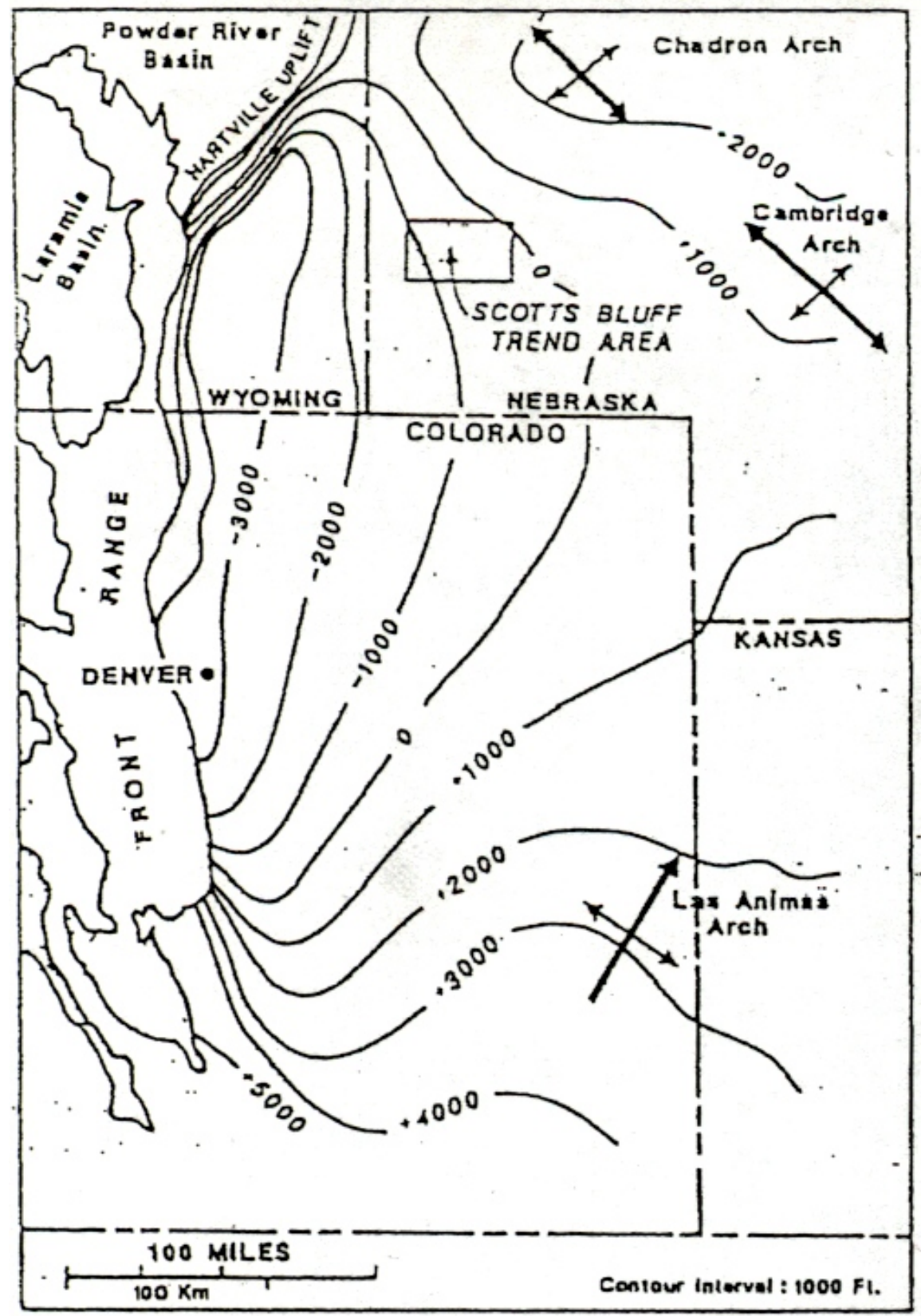

Figure 18: Generalized geology of the study area. Structural top of the Dakota Group with a $1000^{\prime}$ contour interval (from Silverman, 1988). 


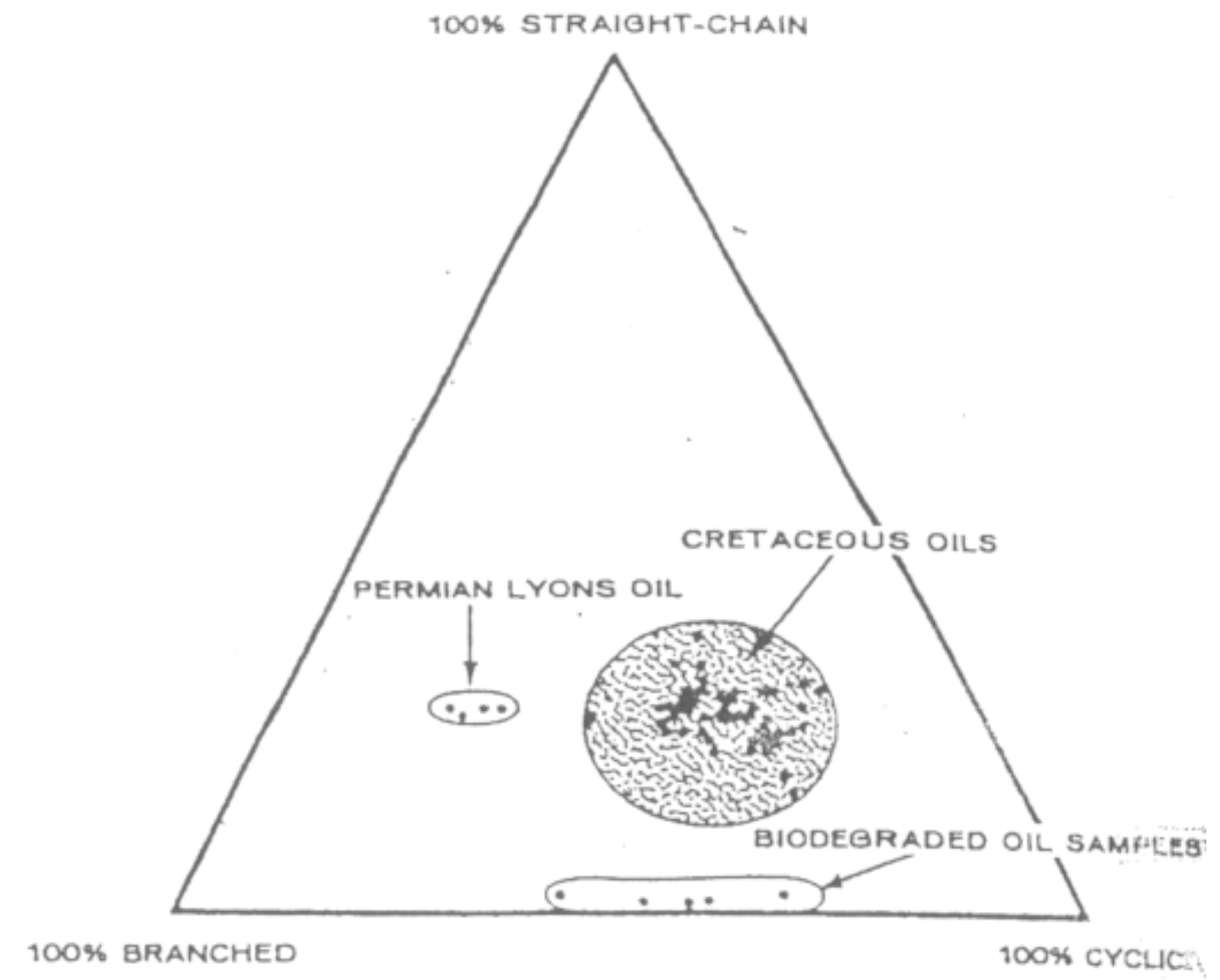

Figure 19: $C_{7}$ hydrocarbon distribution of Denver Basin oils. Oils produced from different Cretaceous-aged reservoirs from throughout the Denver basin are compositionally similar (from Clayton and Swetland, 1980). 
age, from youngest to oldest in age: Pierre Shale, Niobrara Formation, Carlile Shale, Greenhorn Limestone, Graneros Shale, Huntsman-Mowry Shale interval, and the Skull Creek Shale (Clayton and Swetland, 1980).

Vitrinite reflectance $\left(\% R_{0}\right)$ values in Figure 20 illustrate the various levels of thermal maturity found in these Cretaceous shales. These graphs are gas chromatograms of $\mathrm{C}_{15}+$ saturated hydrocarbon fractions for their respective formation at these different levels of maturity. Samples 32 and 22, which are from eastern Colorado and Wyoming, have $\% R_{0}$ below that of thermally mature shale $\left(<0.60 \% R_{0}\right)$. Whereas, samples 20 and 36, from the same two formations, are from locations closer to the basin's axis and have thermally mature $\% R_{0}$ values $(0.60-1.3)$. Figure 21 is a geographic distribution of average vitrinite reflectance values calculated in the study. On the outer margins of the Denver basin, such as Scotts Bluff Trend, the potential source beds are thermally immature $\left(<0.60 \% \mathrm{R}_{0}\right)$ (Clayton and Swetland, 1980).

Clayton and Swetland (1980) also looked at cuttings from two wells, from the same formations listed above, in southwestern Nebraska and compared them to several crude oils from the producing formations in the area. Figure 22 shows the comparison of the $\mathrm{C}_{7}$ hydrocarbon compositions of these cuttings to those of the oils. Oil stained cuttings $(6 \Delta)$ from the J Sandstone interval of the 1-1 Gadeken well is also plotted. The essence of this diagram is that the shale cuttings, above and below the J Sandstone, have different $\mathrm{C}_{7}$ distributions than the $\mathrm{J}$ sample and crude oils. Thus it is concluded that the oils produced in the western panhandle of Nebraska have laterally migrated into the area from thermally mature source beds near the basin axis (Clayton and Swetland, 1980). 
Knowing that the hydrocarbons produced in Scotts Bluff Trend are from a deeper, more thermally mature portion of the basin gives credit to Silverman's (1988) hypothesis that faults acted as a migration route for oil and thus oil accumulation is limited to the trend. The author will address this issue later in the structural analysis portion. Again, knowledge of the oil migration mechanism will lead to a further reduction in exploration risk when searching for reservoirs. 

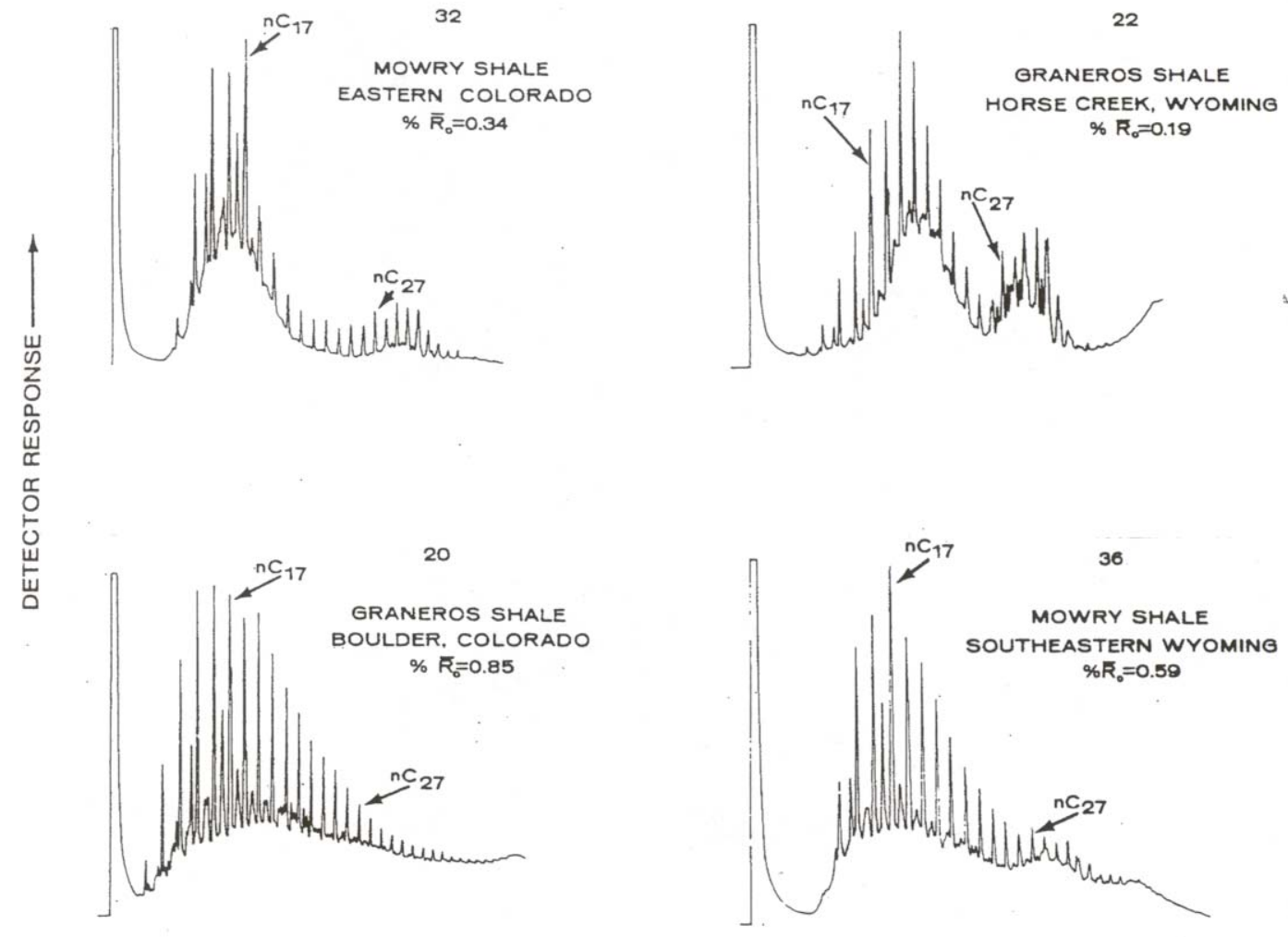

RETENTION TIME $\longrightarrow$

Figure 20: Vitrinite reflectance $\left(\% R_{\circ}\right)$ values with their respective gas chromatograms of $\mathrm{C}_{15}$ + saturated hydrocarbons from selected shales within the Denver basin. Thermally mature shales (samples $20 \& 36$ ) have $\% R_{\circ}$ values ranging from $0.6-1.3$ and a single peak gas chromatogram distribution. Bimodal gas chromatograms (sample $22 \& 32$ ) and lower $\% R_{0}$ values $(<0.60)$ reflect thermally immature shales. $\% R_{\circ}$ values from eastern Colorado (sample 32 ) are representative of southwest Nebraska $R_{\circ}$ values (from Clayton and Swetland, 1980). 


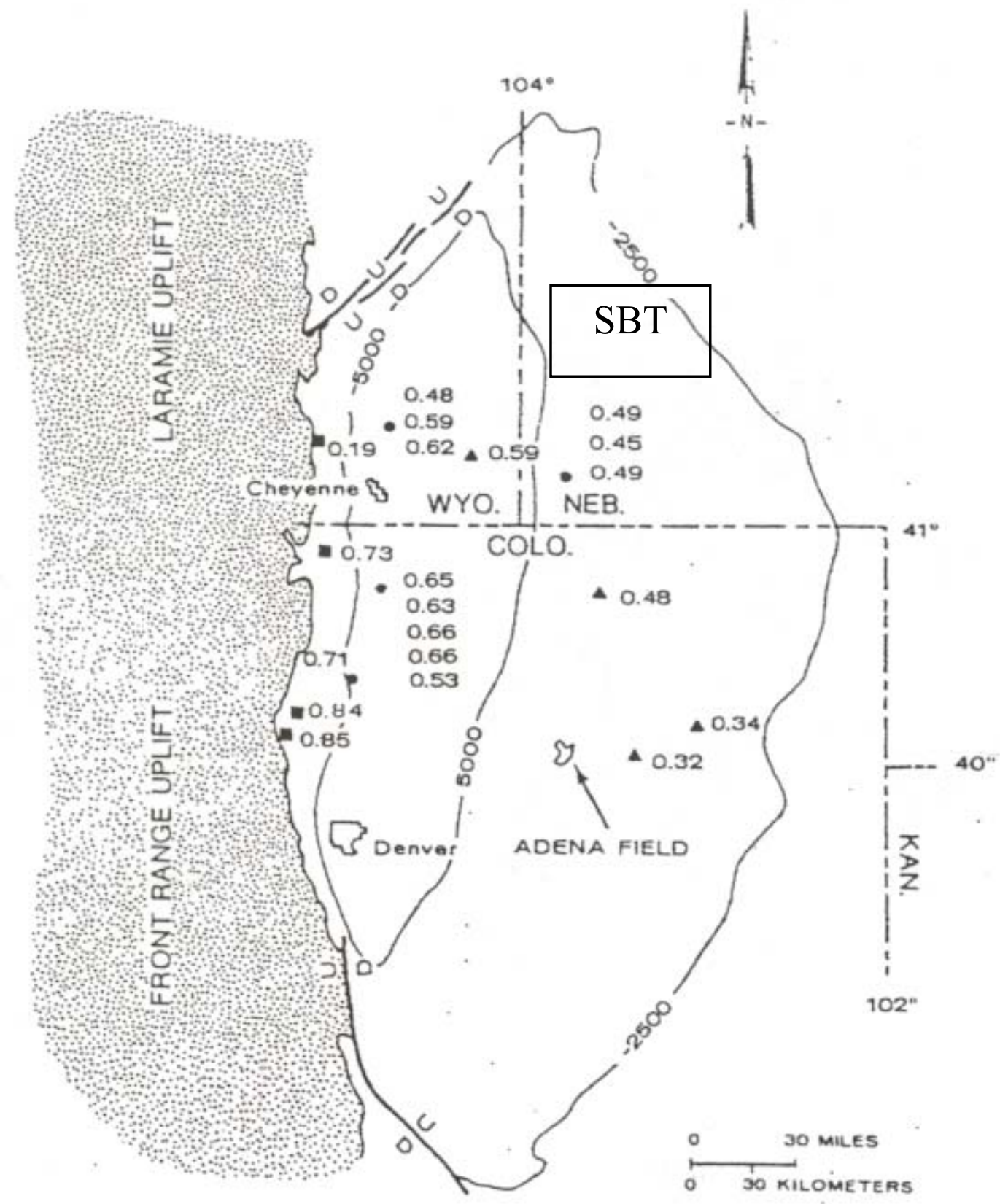

Figure 21: Distribution of vitrinite reflectance values of shales throughout the Denver basin. Along the basin axis, thermally mature shales have vitrinite reflectance values ranging from $0.62-0.85 \% R_{0}$, while the basin flanks (eastern Colorado, western Nebraska) have immature shales below the critical $0.60 \% R_{\text {。 }}$ value (modified from Clayton and Swetland, 1980). 


\section{$50 \%$ STRAIGHT CHAIN}

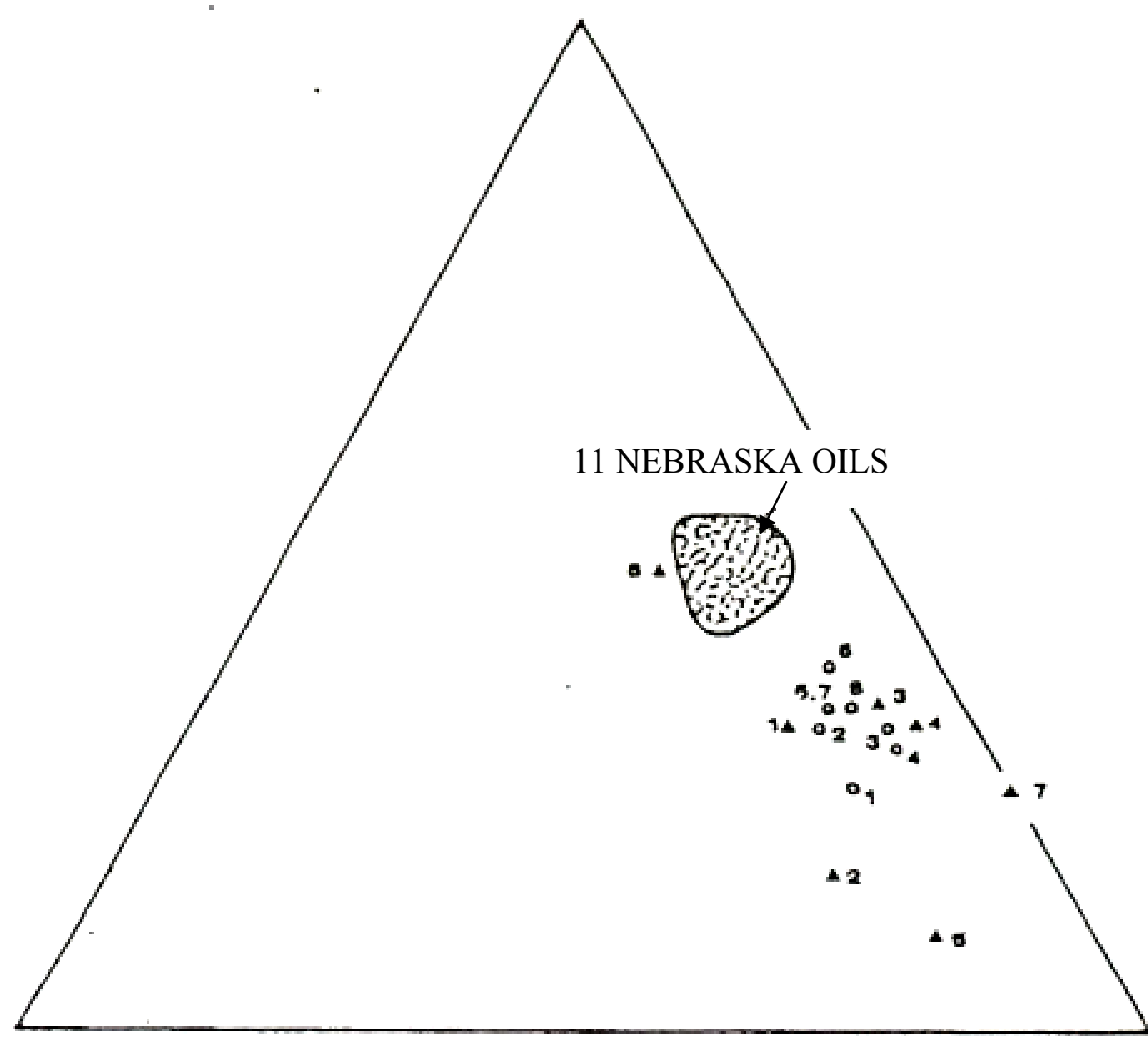

Figure 22: $C_{7}$ hydrocarbon distributions of shale cuttings and oil samples taken from two wells in southwestern Nebraska. Included is a stained $\mathrm{J}$ Sandstone cutting $(6 \Delta)$ from one of these wells. The oil stained $\mathbf{J}$ sample and produced oils from the area are compositionally the same. Note, there is a disconnect between the $\mathbf{J} \&$ oil sample compositions and the shale compositions. Produced oils had to migrate laterally into the area (modified from Clayton and Swetland, 1980). 


\section{ANALYTICAL APPROACH}

Reexamination of the Scotts Bluff Trend (Silverman, 1988) for potential reservoirs was carried out by structural, stratigraphic and exploratory means. The database for this project comprised well header information in spreadsheet form, abridged geophysical well logs, and data derived from hand-contoured structure maps. The spreadsheet data, obtained from Dr. Dave Oldham, included the API well number, operator, well name, latitude, longitude, well status, well class, total depth of well, datum elevation and reference, ground elevation, county, spud date, completion date, township, range, section and footage information for approximately 3000 wells. Also obtained from Dr. Oldham were approximately 500 abridged geophysical well logs that only included the prospective D and J Sandstone intervals. The last part of the database was collected from hand-contoured structure maps produced by Mr. Dick Oleson. The Oleson maps contain 2692 subsea depths for the top of the J Sandstone.

When this data were first acquired, the Oleson maps had API numbers attached to each well. In contrast, the well card appended to each geophysical well log lacked this data but had quarter / quarter information for the appropriate section, township and range. In order to combine these data sets, I pulled each well log, located it on the Oleson maps and transposed the API number onto each well log.

A geographic grid was selected larger than the intended study area so that future expansion on the study was possible, if so desired. GeoGraphix Discovery ${ }^{T M}$ was used in the creation of a grid that extends from $42.25^{\circ} \mathrm{N}-103^{\circ} \mathrm{W}$ (southwest corner) to $41.5^{\circ} \mathrm{N}$ $-104.185^{\circ} \mathrm{W}$ (northeast corner) (T18N - T25N and R50W - R58W). The project was 
created so that all the information imported was in latitude and longitude coordinates and the output maps, in UTM. Once this grid was established, all the well-header information and $\mathrm{J}$ Sandstone subsea tops collected from the Oleson maps were imported into GeoGraphix Discovery ${ }^{T M}$. Figure 23 depicts a map with the available data points collected in this study.

At this point I was ready to start correlating the approximately 500 geophysical well logs. To aid in the interpretation of structural controls on and stratigraphic geometry of the J1 Sandstone, a marker bed (a consistent resistivity and conductivity kick) within the overlying Huntsman Shale was correlated. Figure 24 shows the three correlations made during the course of this research, as well as the maximum resistivity (from the deep induction curve) within the interpreted J1 zone, and the net J1 sand.

Because a diverse log suite has been collected over the years, net J1 Sandstone thickness is based on a variety of well logs. The main source of this information came from the microlog if it was run in the hole. The function of the microlog is to identify presumed permeable zones within a formation. Where separation on this log was seen, the thickness of this separation was measured as net J1 Sandstone. However, only a portion of the wells had micrologs. Because the microlog, SP and deep-induction curves are all a function of the resistivity of the formation fluid, a correspondence exists between their respective deflections. Hence, a permeable zone on the microlog could be correlated to the SP and deep-induction log signatures. Where there is a more pronounced deflection in either of these logs, permeability was interpreted.

Drill stem tests (DST) and core information (from well cards) were also used when available. For instance, without a microlog, a small deflection on the SP and deep 




Figure 23: Map showing the areal extents of 500 data points with well logs. 
induction curves would not usually be interpreted as the net J1 Sandstone. However, a core description of sandstone with good porosity and an oil stain that coincides with these same small deflections would be indicative of net J1 Sandstone.

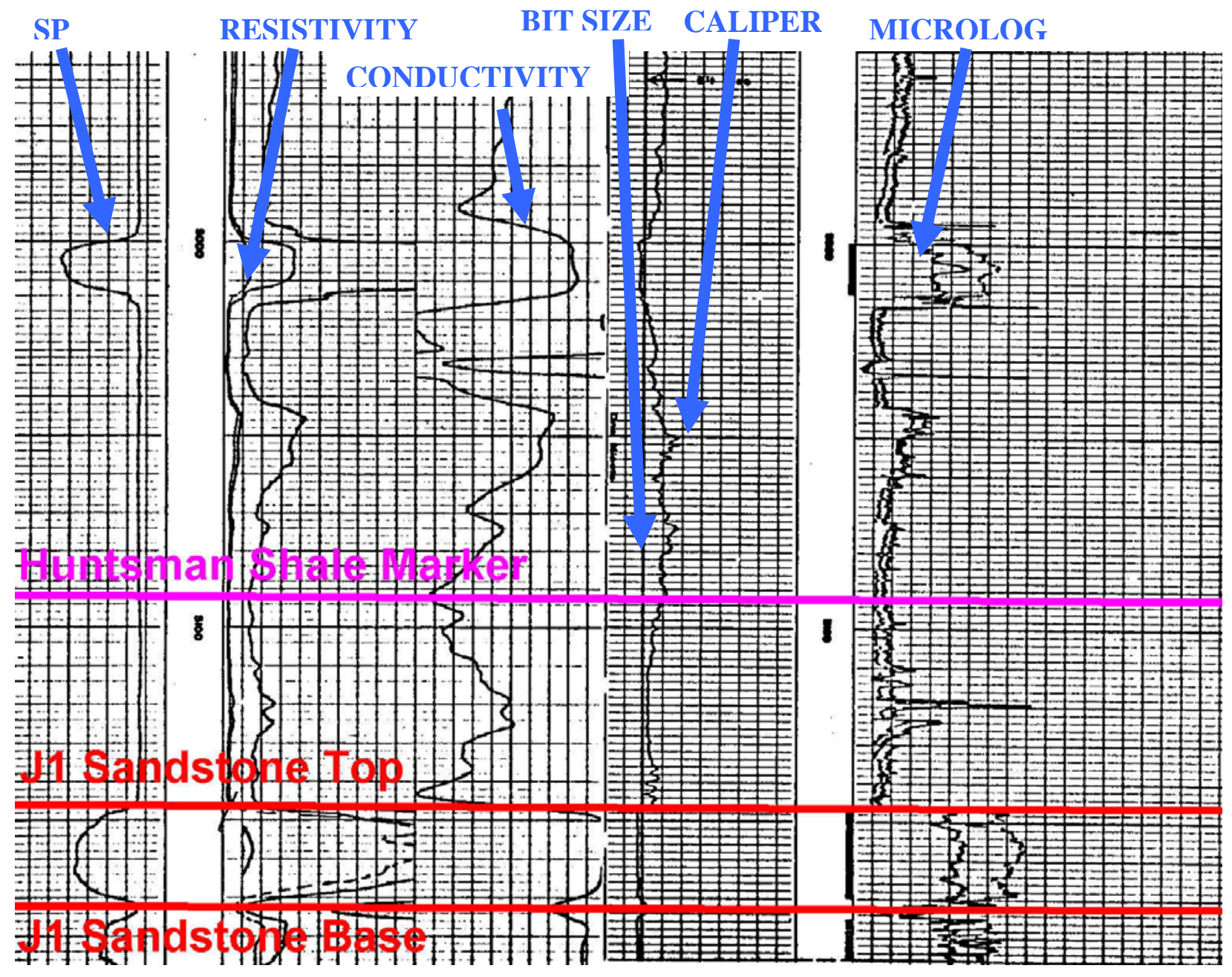

Figure 24: Sample well log (26157051290000, Section 28 - T21N - R55W, NENE) showing the three picks. 


\section{INTERPRETATION OF MAPS AND CROSS-SECTIONS}

\section{STRUCTURE}

The J1 Sandstone mapped in the following sections is equivalent to Exum and Harms' (1968) upper J1 facies and Graham's (2000) MS-4 informal member. Structurally, Silverman (1988) inferred that the Scotts Bluff Trend is related to recurrent movement along northeast-trending Paleozoic fault/shear zones. Based on source rock and oil geochemistry, it is believed that hydrocarbon accumulations in western Nebraska are allochthonous (Clayton and Swetland, 1980). If recurrent movement along older faults has occurred, one is left to assume that these fault zones are the potential pathways for hydrocarbon migration into the area. Thus oil accumulations would only be situated within this trend. This chapter intends to further analyze this idea.

\section{J SANDSTONE STRUCTURE}

Figure 25 is a structure map based on the top of the $\mathrm{J}$ Sandstone with a contour interval of 50 feet $(15 \mathrm{~m})$. This map shows the regional dip at the northeast extension of the Denver basin. The structure here is moderately monoclinal in nature, with an overall dip to the southwest of approximately 1.2 degrees.

Structural "nosing" is associated with most of the oil fields that lie within Silverman's (1988) Scotts Bluff Trend fairway. One of the most pronounced is located at Minatare field, which is positioned around Sections $19 \& 30$ of T22N - R53W. Figure 26 shows a zoomed in view of Minatare field, a higher resolution structure map on top of the J Sandstone. Also shown are Power Plant field (section 14 of T22N-R54W) and 




Figure 25: Structural contour map of the top of the J Sandstone. 10 known oil fields are labeled. Note the structural "nosing" that extends across the trend. Contour interval $\mathbf{5 0}$ feet. Each section is approximately one square mile in area. 


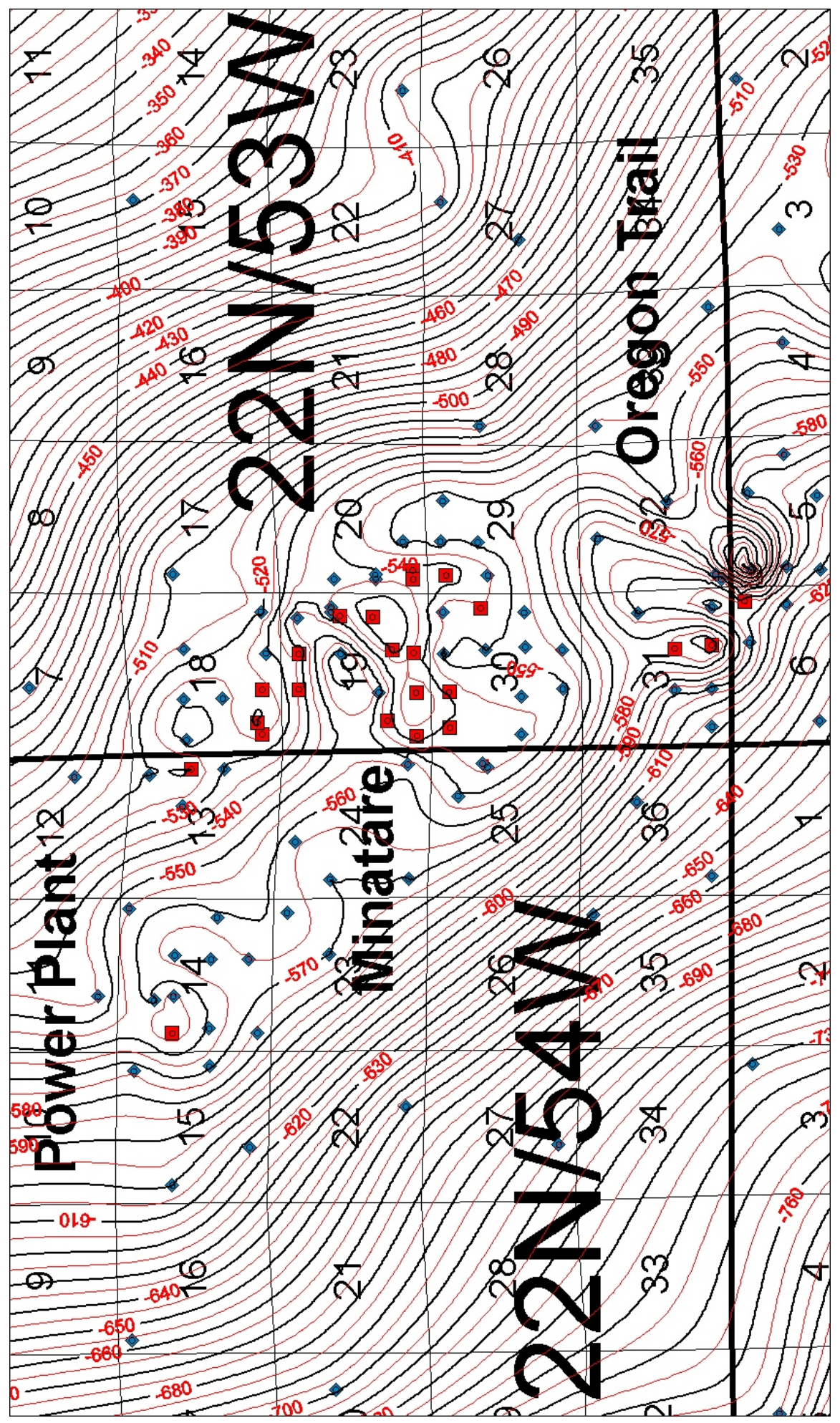

Figure 26: High-resolution structural contour map of Minatare field. Red squares indicate producing wells while blue diamonds show dry holes. Contour interval 5 feet. Each section is approximately one square mile in area. 
Oregon Trail field (section 31 of $\mathrm{T} 22 \mathrm{~N}-\mathrm{R} 53 \mathrm{~W}$ ). With this view, it can be seen that these three fields have structural closures on the updip edge of the reservoir.

Coincidently, these updip structural closures have a corresponding downdip structural "nose".

These nosing features can be followed in a northeast direction where the study area extends into Morrill County, Nebraska (Figure 25). Here resides the eastern-most fields within the study. Highline (section 31 of T23N - R52W) and Mustang Canyon fields (section 11 of T22N - R52W) also have this same updip structural closure associated with a downdip structural nose (Figure 27). Production from the Highline field can also be seen on the flanks of the structural "nosing".

There are two other areas with structural nosing within the study area (Figure 25), however, they lack any known reservoirs on their updip edges. One such structure is located north of Minatare field, around section 1 of T22N - R54W. The other locale is in the southwest sector on T23N-R55W. Again, there is a structural nose that extends to the southwest that lacks an associated reservoir.

Southwest of Minatare field, this structural nosing continues (Figure 25). Here lies the largest oil field in the study, Cedar Valley field (sections $20,21 \& 28$ of T21N R55W). Also present are small two- to five- well oil fields (Figure 28): Fort Laramie (sections 13 \&14 of T21N - R56W), Roubadeau (section 26 of T21N - R56W), Vessels (sections 35 \& 36 of T21N - R56W), and Canal (section 34 of T21N-R55W) fields. In this part of the study area, only Canal field exhibits the updip structural closure seen in the other fields. 


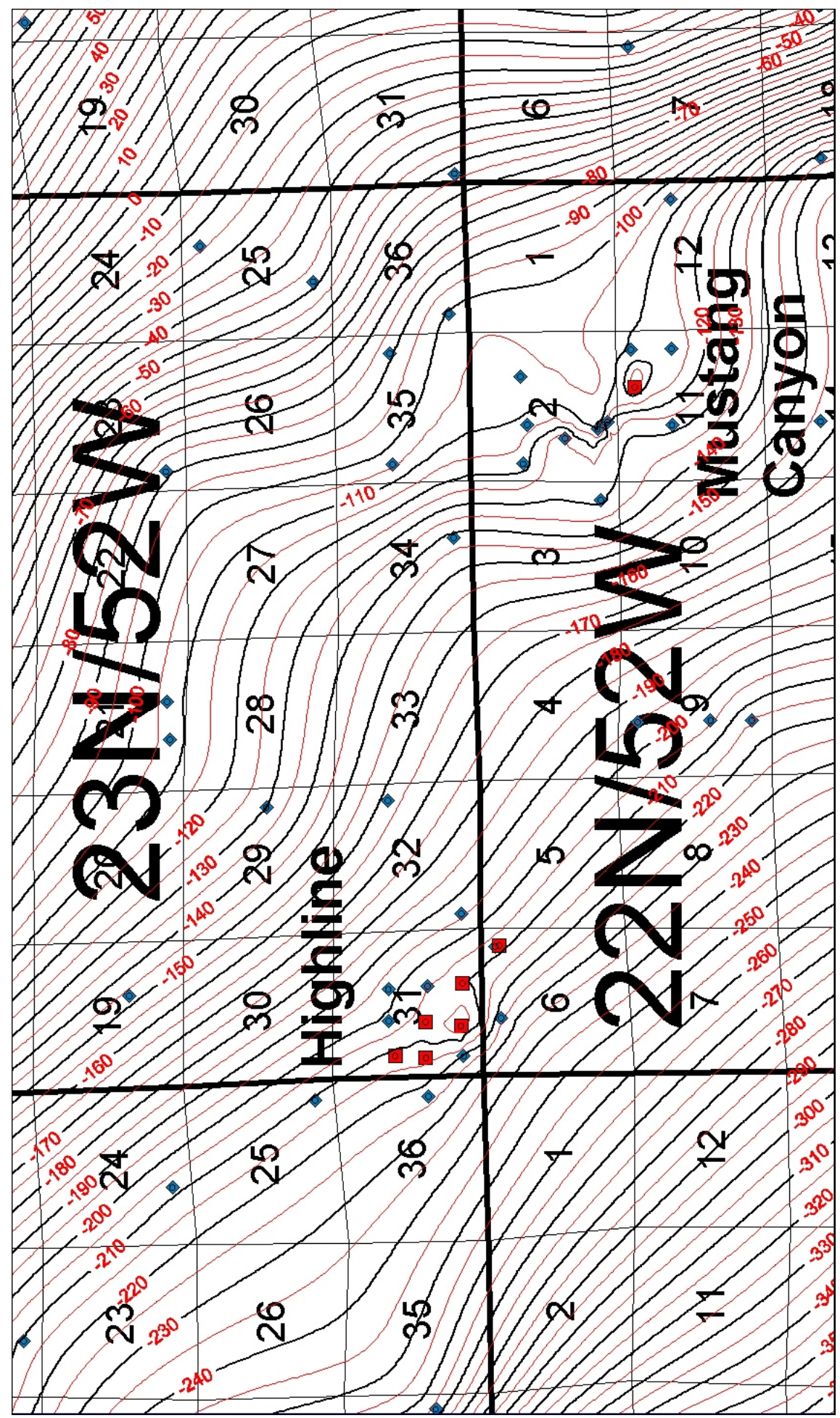

Figure 27: High-resolution structural contour map of Highline and Mustang Canyon field. Red squares indicate producing wells while blue diamonds show dry holes. Contour interval $\mathbf{5}$ feet. Each section is approximately one square mile in area. 


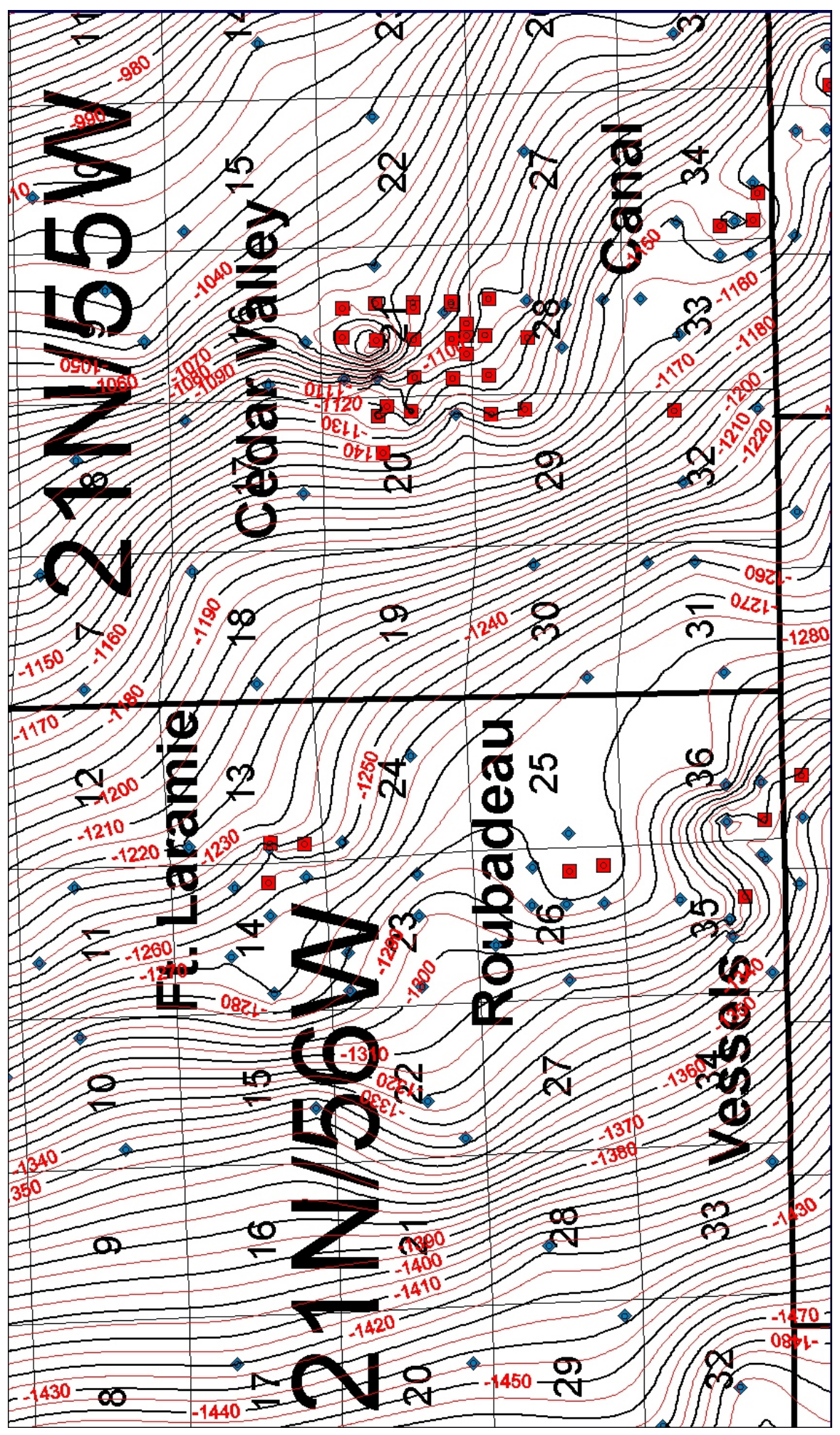

Figure 28: High-resolution structural contour map of Cedar Valley field. Red squares indicate producing wells while blue diamonds show dry holes. Contour interval $\mathbf{5}$ feet. Each section is approximately one square mile in area. 
Well data at Cedar Valley field reveals there is no structural closure; stratigraphy must be the major factor in oil entrapment. Although well control is poor surrounding the three fields west and south of Cedar Valley, apparently structural closure is absent there, as well. Because of poor well control, this issue remains unresolved.

\section{$2^{\text {nd }}$ ORDER RESIDUAL MAP OF THE J SANDSTONE STRUCTURE}

Figure 29 depicts the second order trend surface that GeoGraphix Discovery ${ }^{T M}$ created by applying algorithms. These algorithms remove local irregularities within the study area, resulting in a structure map that is smoothed. Residual mapping of the $\mathrm{J}$ Sandstone structure map was completed by subtracting the regional trend of the data points from the original structure map (Figure 25), resulting in the identification of highs and lows between the trend and the structure.

Figure 30 displays a second order residual map based on the J Sandstone structure, shown at a 10-foot $(3 \mathrm{~m})$ contour interval. Revealed in the middle of the study area is a large positive feature ( $>50$ feet, $15.2 \mathrm{~m}$ ) that extends from southwest of Cedar Valley field to northeast of Minatare field. This residual high is oriented with a $\mathrm{N} 60^{\circ} \mathrm{E}$ trend that coincides with Silverman's (1988) Scotts Bluff Trend (Figure 1). Immediately to the southwest of Minatare and Power Plant fields lies the most pronounced residual high in the study area. Here a northwest-to-southeast trending pod is situated with approximate dimensions of 7 miles $(11 \mathrm{~km})$ in length, 2 miles $(3 \mathrm{~km})$ in width and maximum relief of 80 feet $(24 \mathrm{~m})$.

To the northeast of Minatare field, residual mapping shows a relative residual low (section $17 \& 20$ of T22N - R53W) as compared to the southwest of the field. This low coincides with the previously discussed structural closures associated with the three oil 


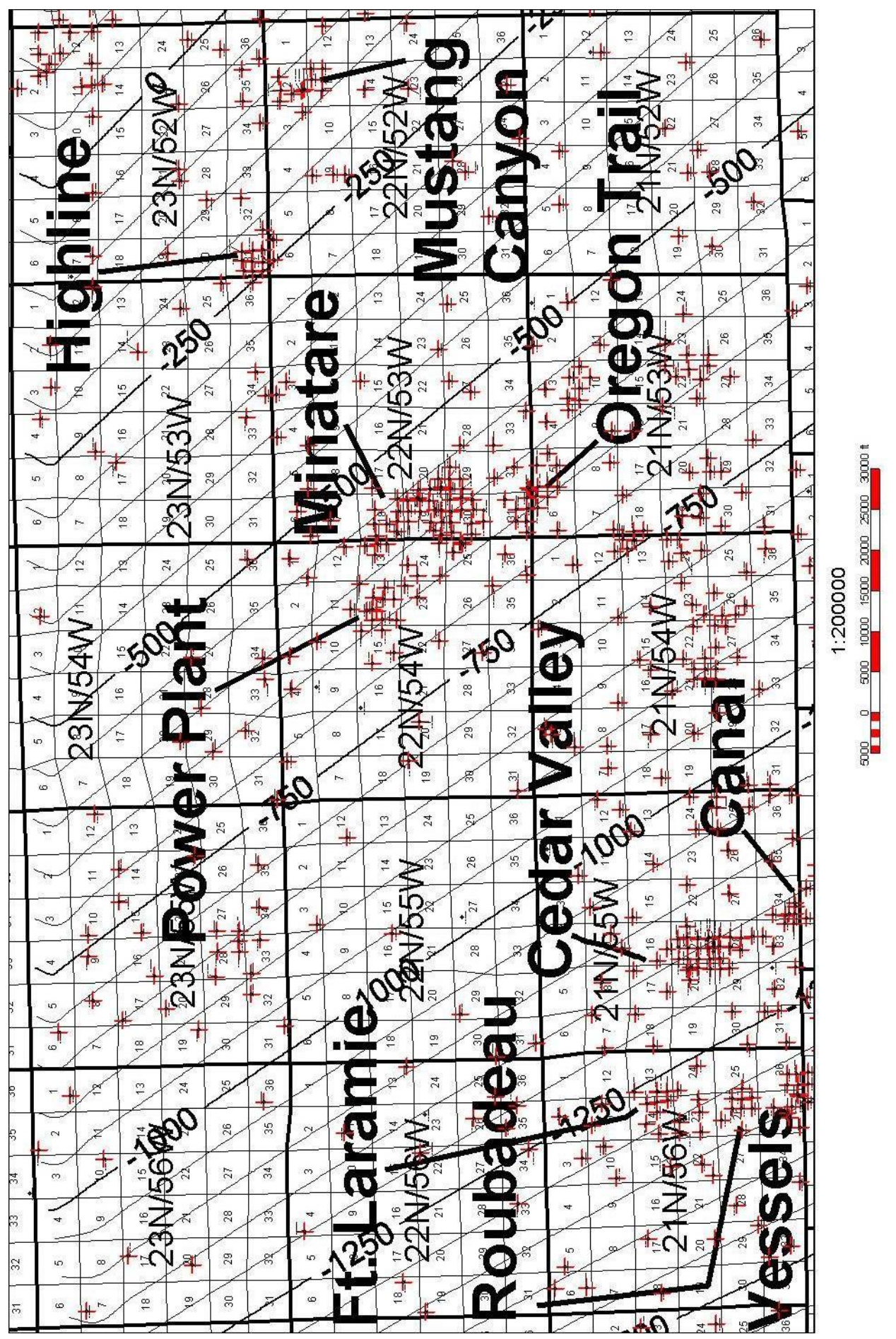

Figure 29: Second Order Trend map of the J Sandstone structure. Contour interval 50 feet. 

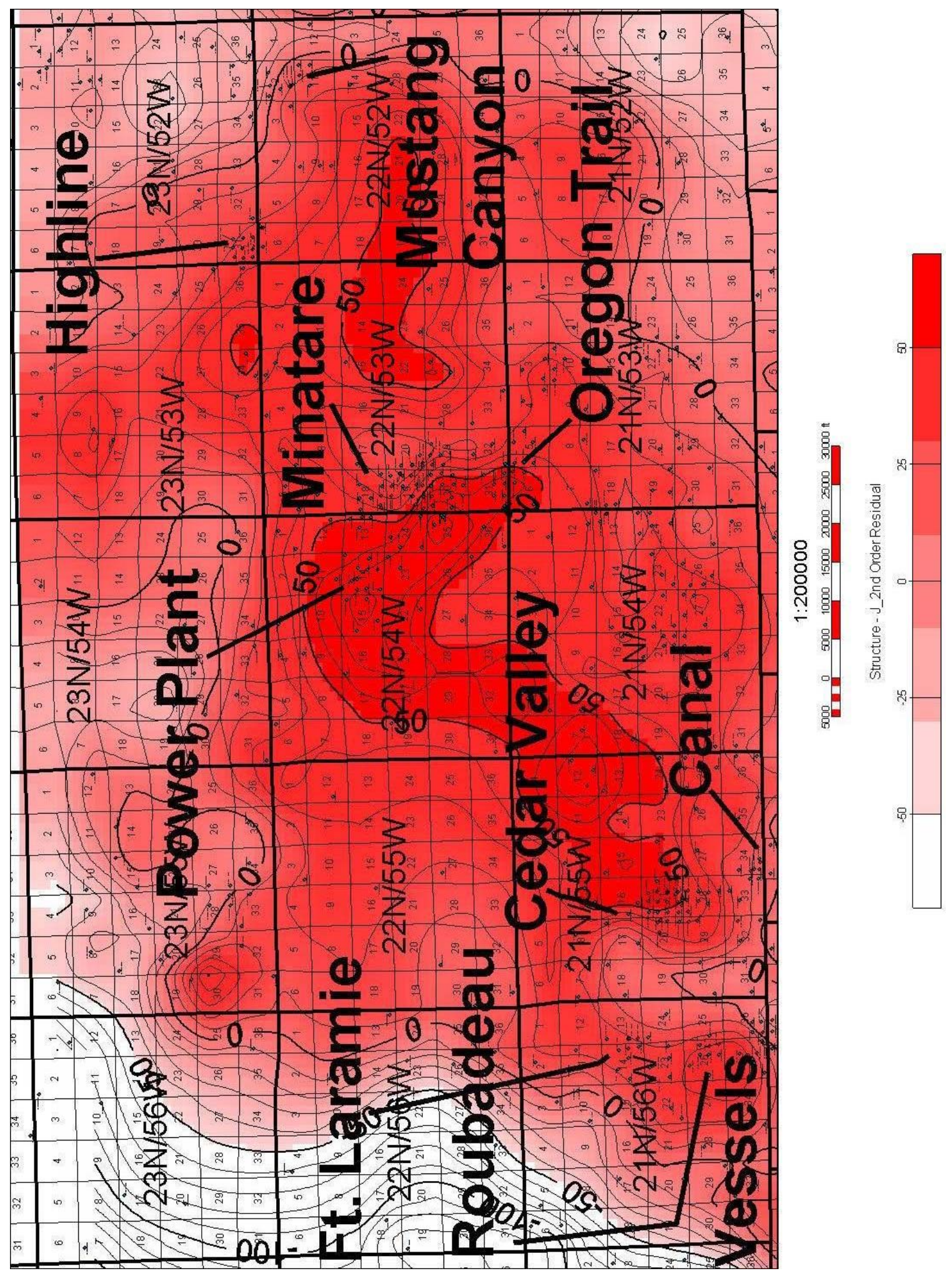

Figure 30: Second Order Residual map of the J Sandstone structure. Note the residual high that corresponds to Silverman's trend. Contour interval 10 feet. 
fields in the area (Figure 26). Between Minatare, Highline and Mustang Canyon fields there is another residual high. This high is oriented in an east - west trend with dimensions approximately being 11.5 miles $(18.5 \mathrm{~km})$ in length, 4 miles $(6 \mathrm{~km})$ in width and maximum relief of 50 feet $(15 \mathrm{~m})$.

Northeast of Highline and Mustang Canyon fields the residual high of Scotts Bluff Trend apparently ends. However, the data here are sparse and contouring may be a reflection of this.

In the southwestern portion of the study area, the main residual high extends to Cedar Valley field. This residual high is observed at Fort Laramie, Roubadeau and Vessels fields although structural relief is smaller, $20-30$ feet $(6.1-9.1 \mathrm{~m})$. A sag (low) separates Cedar Valley field from Fort Laramie, Roubadeau and Vessels fields, similar to that located east of Minatare field. South of Cedar Valley field, Canal field is located on the edge of this main high.

In summary, all of the fields are in some way associated with the highs located on this residual structure map (Figure 30). Power Plant, Cedar Valley, Fort Laramie, Roubadeau and Vessels fields all lay upon this high, while Minatare, Oregon Trail, Highline, Mustang Canyon and Canal fields lay on the edges of it. The fields that lay on the edge of this main residual high all have an updip structural closure associated with them (Figures 26, $27 \& 28$ ).

\section{STRATIGRAPHY}

Understanding the geometry of reservoirs and their adjacent strata gives helpful insight into interpreting depositional environments. Once the environment of deposition 
is known, predictions can be made as to where additional reservoirs exist. The following section aims to do just that.

\section{ISOPACH OF HUNTSMAN SHALE MARKER TO J SANDSTONE}

Figure 31 is an isopach map of the interval between the top of the J Sandstone and a marker bed within the overlying Huntsman Shale. The map is shown with a twofoot $(0.6 \mathrm{~m})$ contour interval. In general, this overlying shale thickens to the north, with a maximum thickness of approximately 100 feet (30 m).

To the northeast of Minatare field and west of Highline field is the thickest zone of this interval of Huntsman Shale. At approximately 10 miles $(16 \mathrm{~km})$ in length, 5 miles (8 $\mathrm{km})$ in width, and 20 feet $(6 \mathrm{~m})$ in relief, this trend is interpreted to be a marine embayment between these oil fields: a thick section of Huntsman Shale filled in the south-trending topographic low. North of Highline and Mustang Canyon fields, a smaller marine embayment extends to the east. These embayments in conjunction surround the J1 Sandstone in these 2 fields on three sides. In the center of the study area (northeast sector of $\mathrm{T} 21 \mathrm{~N}-\mathrm{R} 55 \mathrm{~W}$ ) is another relative thickening of the Huntsman Shale interval. Also in the northwest, a thick can be identified. Again these are interpreted to be marine embayments extending southward.

In the central portion of the study areas, Minatare, Power Plant and Oregon Trail fields are situated along the edge of the northern terminus of a Huntsman Shale thin. At approximately 10 miles $(16 \mathrm{~km})$ in length, 5 miles $(8 \mathrm{~km})$ in width, this thin has 20 feet $(6$ m) in relief. Highline and Mustang Canyon fields sit atop a shale thin that extends north from the southeast corner of the study area. This trend is bordered by marine embayments previously discussed. Directly north of Cedar Valley lies another north 


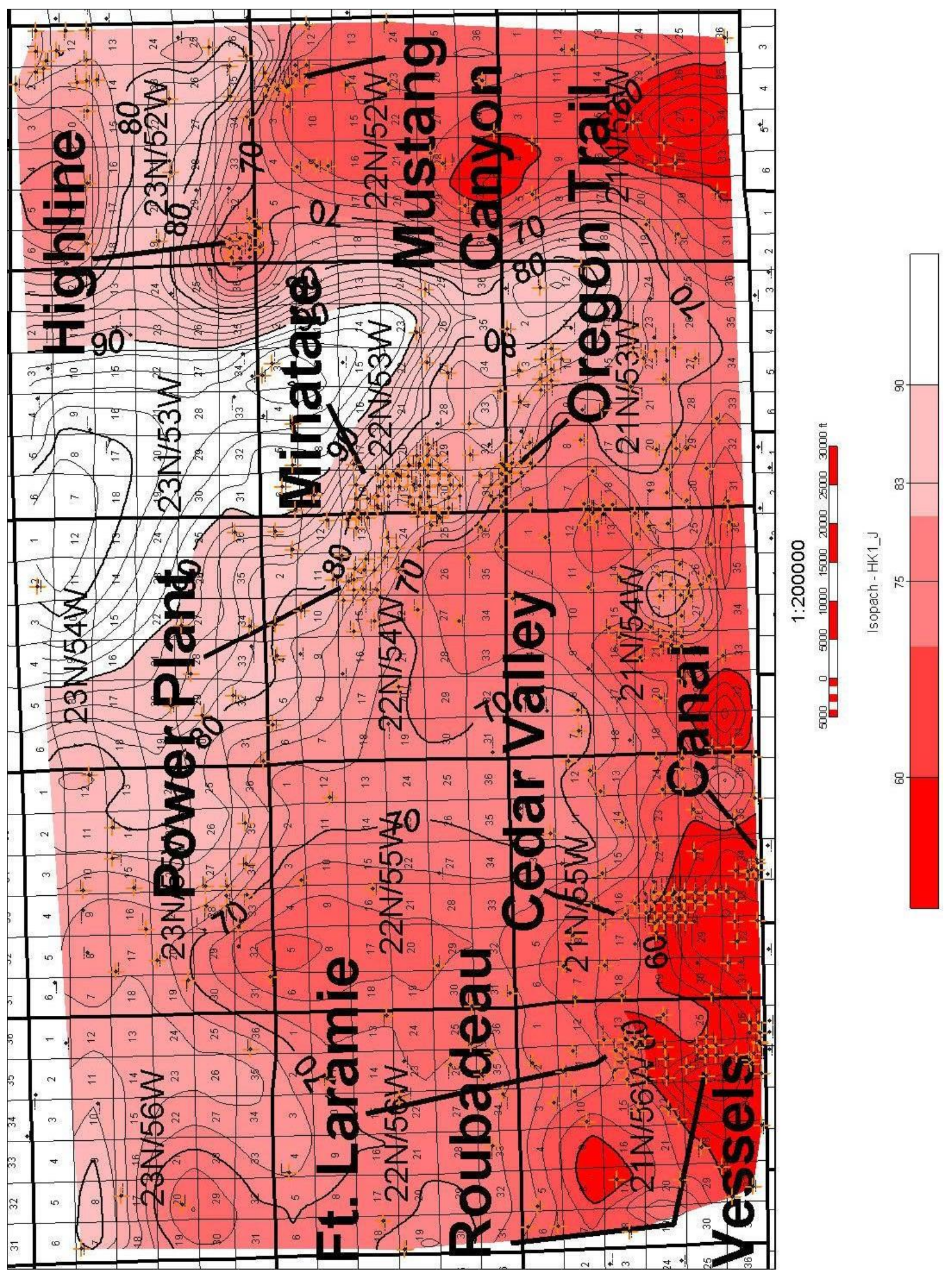

Figure 31: Isopach map from the Huntsman Shale marker to the top of the $J$ Sandstone. Contour interval 2 feet. 
trending shale thin. These shale thins are interpreted to be bathymetric highs at the time of Huntsman Shale deposition.

All of the producing oil fields in the study area are situated around the relative thins of Huntsman Shale (Figure 31). If correspondence were seen between the net J1 Sandstone map and this isopach, an exploration tool would have been found. The build-up of $\mathrm{J1}$ Sandstone in these fields, during a regression of the Western Interior Seaway, would have later provided less accommodation space during the following transgression, which deposited the overlying Huntsman Shale. Hence the areas of thin Huntsman Shale could be an indication of J1 Sandstone deposition.

\section{ISOPACH OF NET J1 SANDSTONE - NO BIAS}

Figure 32 shows the thickness and geographic distribution of the net $\mathrm{J} 1$ Sandstone throughout the Scotts Bluff Trend study area. This map is contoured at a two-foot $(0.6 \mathrm{~m})$ interval and displays maximum thicknesses around Minatare and Cedar Valley fields of approximately 30 feet $(9 \mathrm{~m})$. A complete detailed explanation of the distribution of net J1 Sandstone deposition will be discussed in the next section.

When this map is compared to the same areas on the isopach between the Huntsman Shale marker and the J Sandstone, the two maps show a contradiction in some areas and a correlation in others. Located around the oil field are thicker accumulations of net J1 Sandstone (Figure 32) and thinner accumulations of Huntsman Shale (Figure 31). This correspondence gives evidence to the interpretation of bathymetric highs at the time of shale deposition.

On the contrary, the large Huntsman Shale thick that extends to the northeast of Minatare field (Figure 31) corresponds to a net J1 sandstone accumulation (Figure 32). 

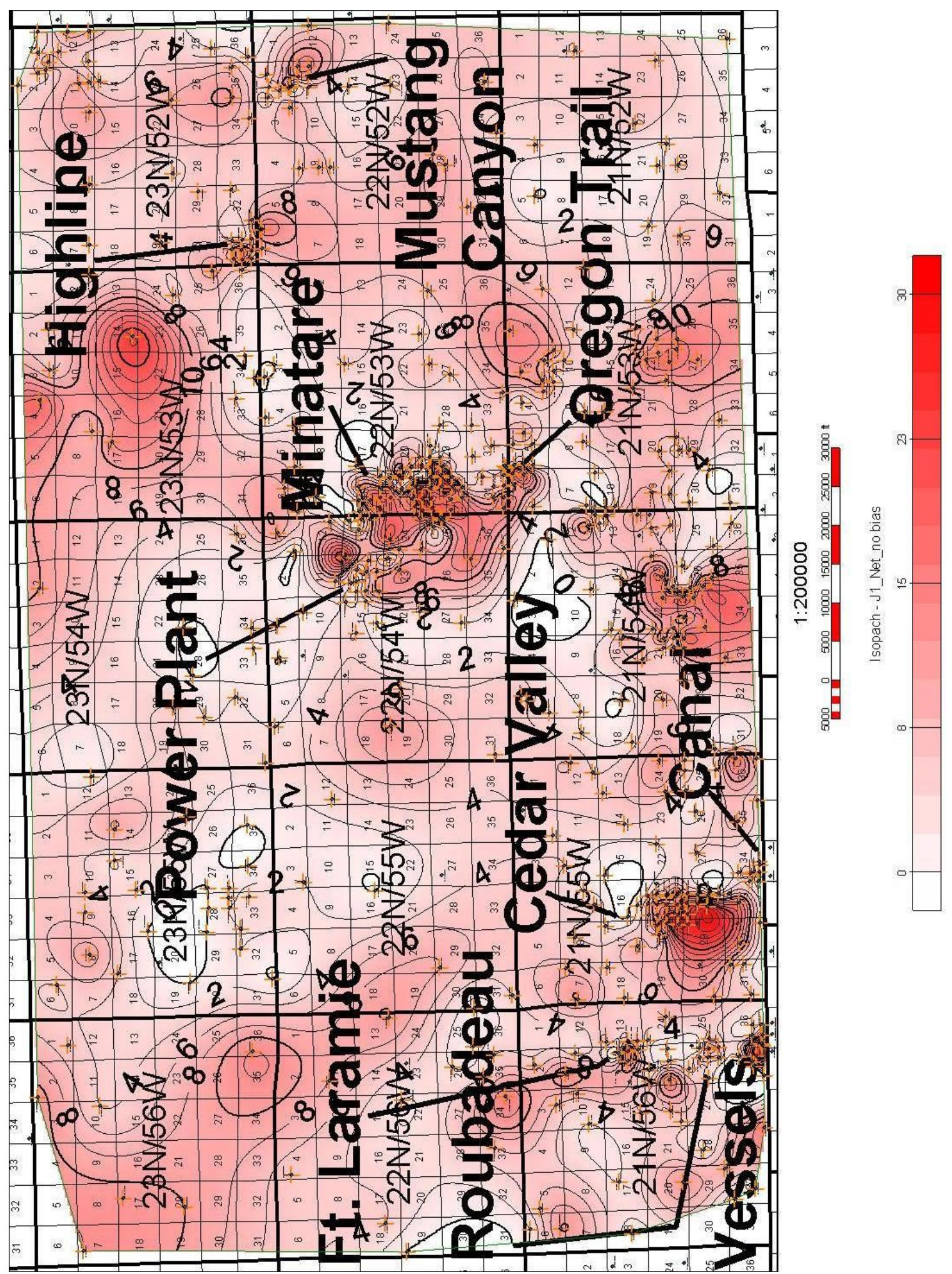

Figure 32: Isopach map of the J1 net Sandstone - no bias. Although contours obey data points, the isopach lacks depositional grain. Contour interval 2 feet. 
North of Cedar Valley field, the shale thin on Figure 31 matches sandstone thinning on Figure 32. This discrepancy may be the result of poor well control in the area because where there is good well control (aforementioned); an inverse relationship exists between the overlying shale and net J1 Sandstone thicknesses.

\section{ISOPACH OF NET J1 SANDSTONE - GEOLOGIC BIAS}

Although the original, previously discussed net J1 Sandstone isopachs are contoured correctly, they might not be geologically realistic. This difference is due to a lack of consideration of depositional grain when using any contouring software package. Consideration of depositional grain is useful when data are sparse or the geology is unknown. These packages contour only data points, unless told otherwise. On the contrary, geologists hand-contour with an understanding of the geology.

A map using a bias trend parallel to Exum and Harms' (1968) northeast trend for

their lower J1 Sandstone is depicted in Figure 33. Shown here are northeast-trending reservoirs within the oil fields that widen or expand in the northwest-to-southeast directions. These pods are contrary to Exum and Harms' elongated reservoirs as previously seen in Figure 5.

Mapping in a northerly orientation, like Exum and Harms' (1968) valley-fill study, is shown in Figure 34. Exum and Harms' (1968) valley-fill (Figure 8) is a thin ribbon-like trend that is long and narrow. The Scotts Bluff Trend J1 Sandstone, when mapped in a north bias, does not fit this character.

Figure 35 illustrates a northwest-to-southeast reservoir trend within the Highline Field reservoir. Due to the placement of the dry holes (blue diamonds), it is concluded 


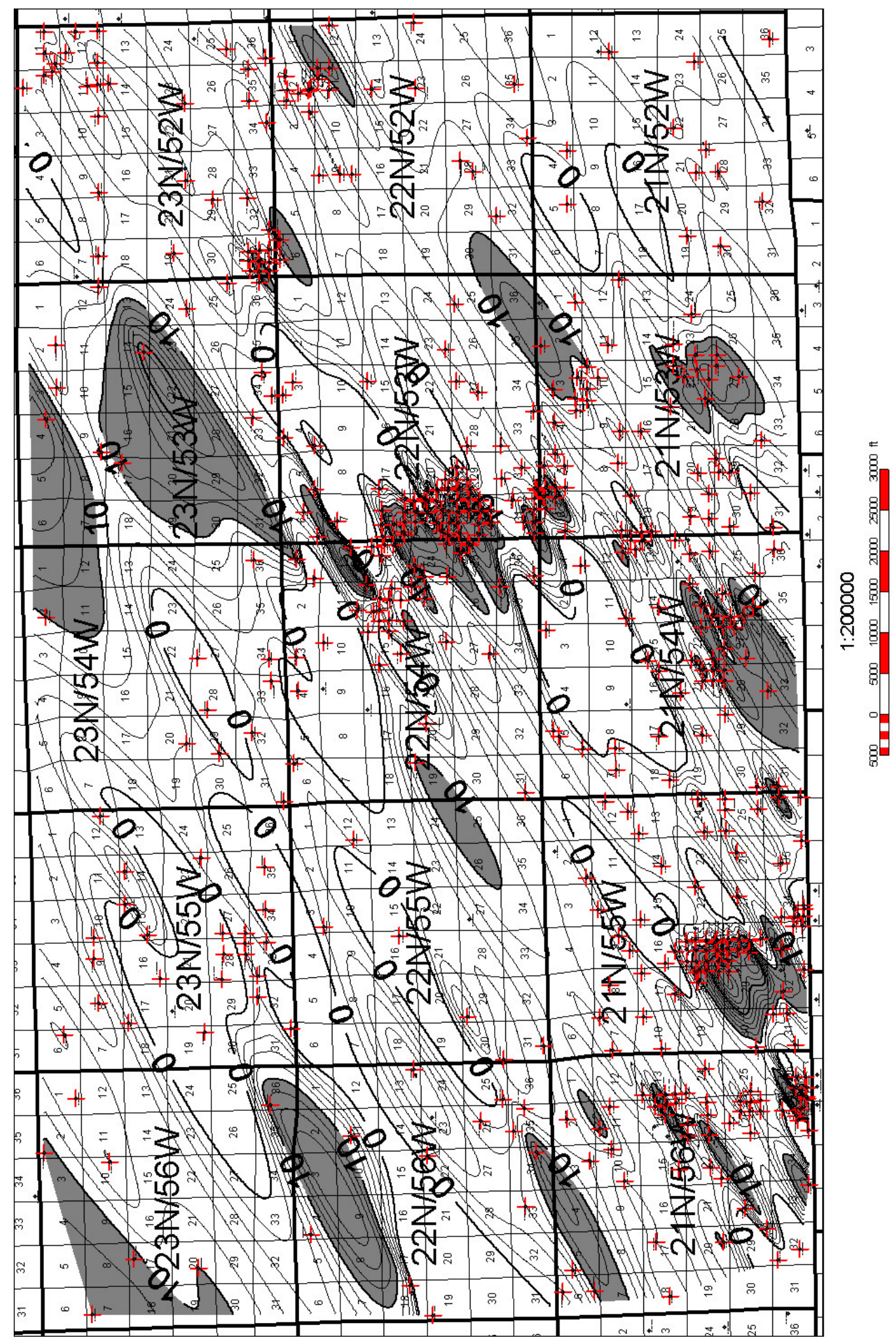

Figure 33: Isopach map of the J1 net Sandstone - northeast bias parallel to Exum and Harms' (1968) northeast trend for their lower J1 Sandstone. Contour interval 2 feet. 


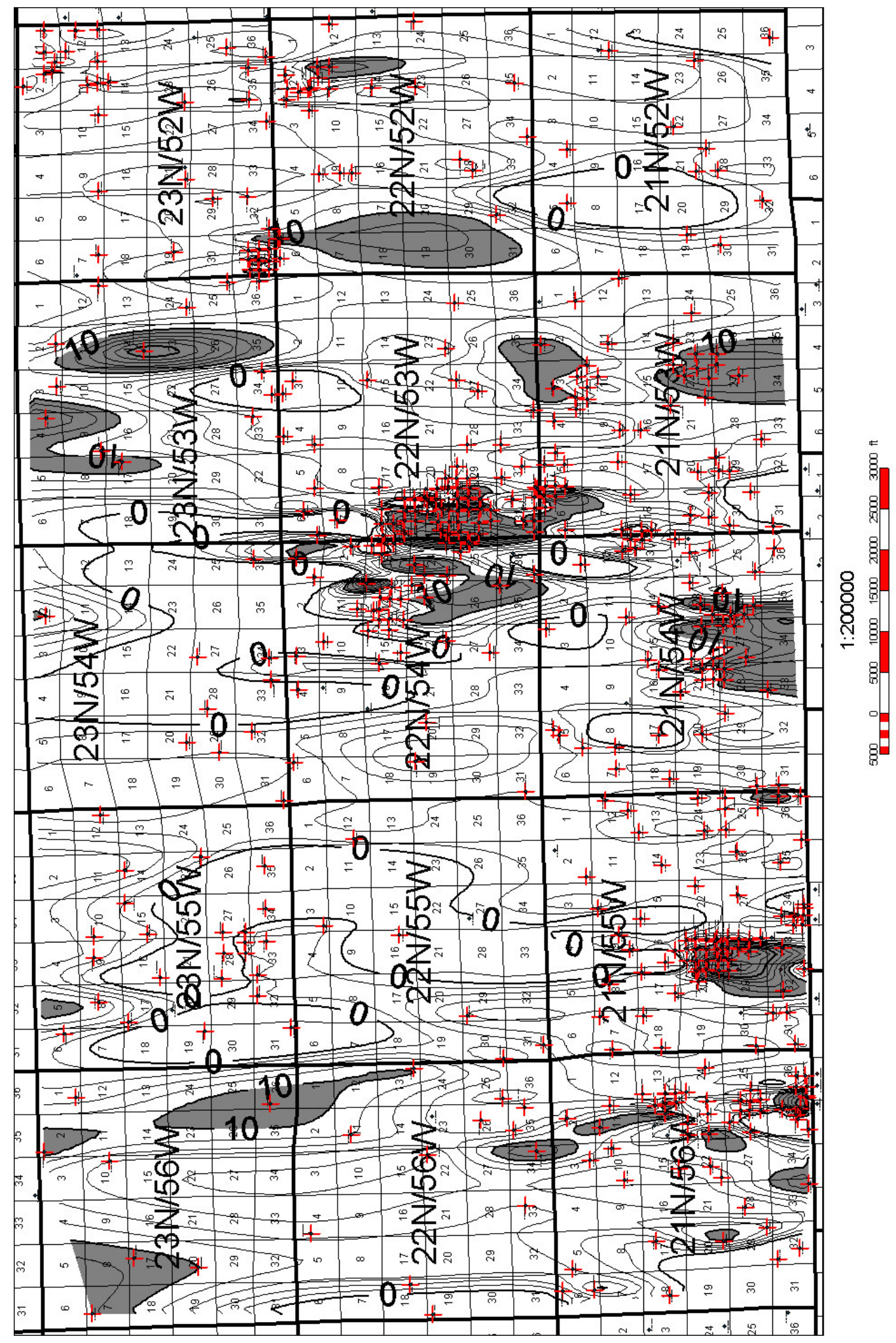

Figure 34: Isopach map of the J1 net Sandstone - north bias parallel to Exum and Harms' (1968) north trending valley-fill. Contour interval 2 feet. 


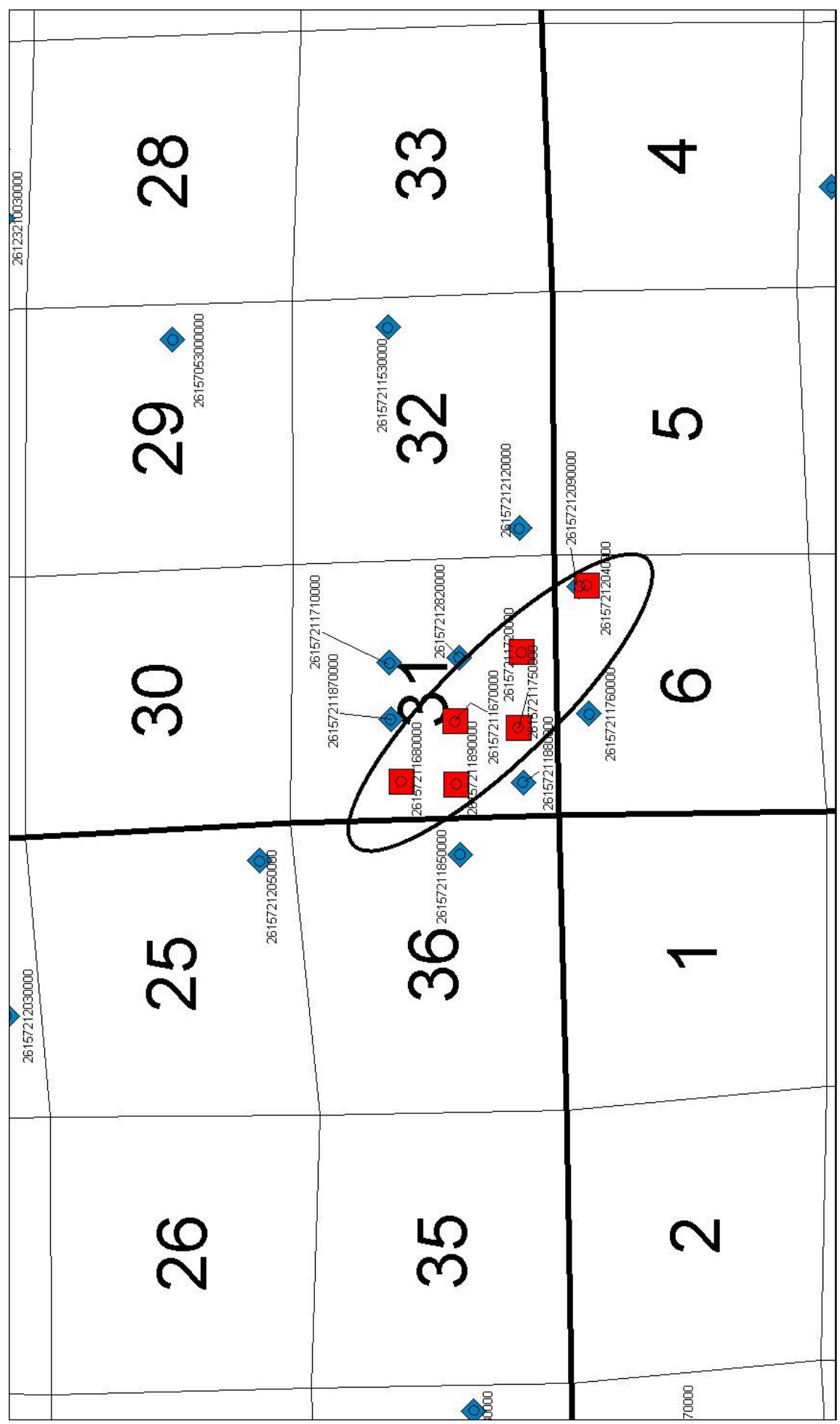

ह

Figure 35: Highline field showing the northwest trends of the reservoirs. Red squares indicate producing wells while blue diamonds show dry holes. 
that the J1 Sandstones within the Scotts Bluff Trend developed in a northwest-tosoutheast orientation.

Figure 36 shows a more geologically realistic interpretation of the distribution of net J1 Sandstone throughout the Scotts Bluff Trend study area. This map is contoured at a two-foot $(0.6 \mathrm{~m})$ interval, with a geologic bias of $330^{\circ}$ and a magnitude of 5 (based on a scale of 10 for preferential weighting). This is based on the understanding of the geology like that displayed in Figure 32 . This biasing is done mathematically through GeoGraphix Discovery ${ }^{T M}$. Once a deposition fabric is construed, a direction $\left(0^{\circ}-360^{\circ}\right)$ and magnitude $(0-10)$ are applied to the unbiased contour map. Depicted in Figure 36 are the same net J1 Sandstone pods displayed in Figure 32 but with the geologic bias applied. This interpretation places the net J1 Sandstone bodies parallel to regional strike.

Overall, the net J1 Sandstone bodies exhibit a northwest to southeast trend. In map view, these pods range from $0.5-1$ mile $(0.8-1.6 \mathrm{~km})$ wide and $1-2$ miles $(1.6-$ $3.2 \mathrm{~km})$ in length. The producing pods range in thickness from $6-28$ feet $(1.8-8.5 \mathrm{~m})$. Spacing between the pods has a two-fold frequency. The larger ones are spaced at about 12 miles $(19.3 \mathrm{~km})$ while the smaller ones exhibit a 2-mile $(3.2 \mathrm{~km})$ spacing.

Around Minatare field, an overall northwest to southeast trending of the net $\mathrm{J} 1$ Sandstone is displayed. This pod of J1 Sandstone is irregular in shape. Northeast and southwest of this pod net sandstone deposition pinches out into siltstone. To the southeast this pod pinches out also, but another pod exists on trend around section 22 of $\mathrm{T} 21 \mathrm{~N}-\mathrm{R} 53 \mathrm{~W}$. 


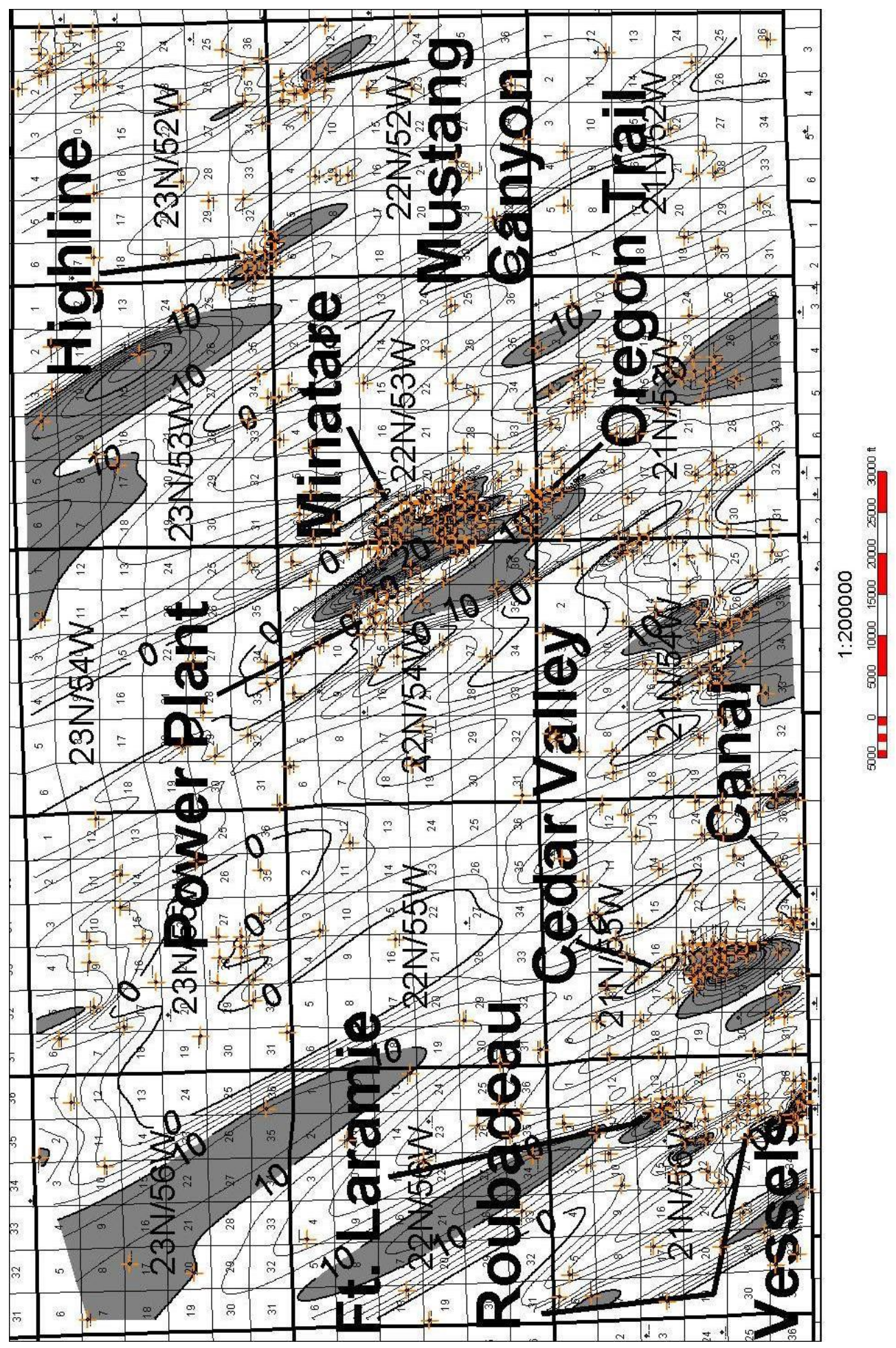

Figure 36: Isopach map of the J1 net Sandstone - northwest bias parallel to Exum and Harms' (1968) northwest trend for their upper J1 Sandstone. Contour interval 2 feet. 
Northeast of Minatare are two more pods of net J1 Sandstone with production. These two are smaller in size compared to the Minatare pod, but reach thicknesses of $10-12$ feet $(3-3.6 \mathrm{~m})$. Highline and Mustang Canyon pods offset each other by approximately 3 miles $(5 \mathrm{~km})$ with dimensions of two miles $(3 \mathrm{~km})$ in length and one mile $(1.6 \mathrm{~km})$ in width. North of Mustang Canyon net J1 Sandstone pinches out into a siltstone, then sandstone deposition occurs again around section 10 of T23N-R52W. No production has been reported in conjunction with this accumulation of net $\mathrm{J} 1$ Sandstone deposition. Northwest of Highline field is another net J1 Sandstone accumulation located centrally in $\mathrm{T} 23 \mathrm{~N}-\mathrm{R} 53 \mathrm{~W}$. Like that of the area to the north of Mustang Canyon, no production has been reported here as well.

Cedar Valley field exhibits the same northwest to southeast trending pod, as does Minatare. To the northeast the net $\mathrm{J} 1$ Sandstone laterally thins into a much siltier section before thickening between Cedar Valley and Minatare fields to approximately 6 -10 feet $(2-3 \mathrm{~m})$ of net $\mathrm{J1}$ Sandstone. This thickening $\mathrm{J1}$ area between Cedar Valley and Minatare fields does not correspond with the previously discussed isopach of the Huntsman Shale (Figure 31). Again, this is attributed to poor well control.

To the southwest of Cedar Valley, net J1 Sandstone deposition exhibits a local thinning. Sandstone deposition thickens farther west around Vessels, Roubadeau, and Fort Laramie fields. Each field has a smaller net J1 Sandstone pod more representative of those found in the northeast part of the study area around Highline and Mustang Canyon fields. These are individual pods of sandstone that laterally grade into a siltier zone and do not have communication. 
In the northwest portion of the study area, a thick net J1 Sandstone pod extends to the southeast. This trend stretches from T23N - R56W to section 29 of T22N R55W. Northeast of this trend, in T23N - R55W, net J1 Sandstone accumulation pinches out into a siltstone. Again, comparison of this area to the shale isopach (Figure 31) shows discrepancy. This inconsistency is again attributed to poor well control.

\section{CROSS-SECTIONS}

Figure 37 shows a base map of the 10 oil fields in the Scotts Bluff Trend study area. Noted on this map are the two largest oil fields by production volume, the Cedar Valley and Minatare fields. Depicted are four cross-sections; two for each field, two parallel to the southwest regional dip ( $A$ and $C$ ) and two parallel to the northwest regional strike (B and D). Each well has a SP, resistivity and conductivity log (from left to right), except for the Schaneman \#23-41 (API \# 26-157-21242-0000) which lacks a conductivity log

Table 1 summarizes the geological information for each well in the following cross-sections. On each of these cross-sections the formation picks (from top to bottom: Huntsman Shale marker bed, J Sandstone top, and J1 Sandstone base) are designated by the red lines, the selected green portions of each well are the net J1 Sandstone intervals and the blue fill indicates the oil - water contact where interpretation is possible. Interpretation is based on oil and water shows in the available core data and resistivity log responses.

Exum and Harms (1968) made facies interpretations based upon core data and concentrations of fixed negative charges (calculated from the SP curve). In essence, these fixed negative charges represent the quantity of clay present. Based upon SP 


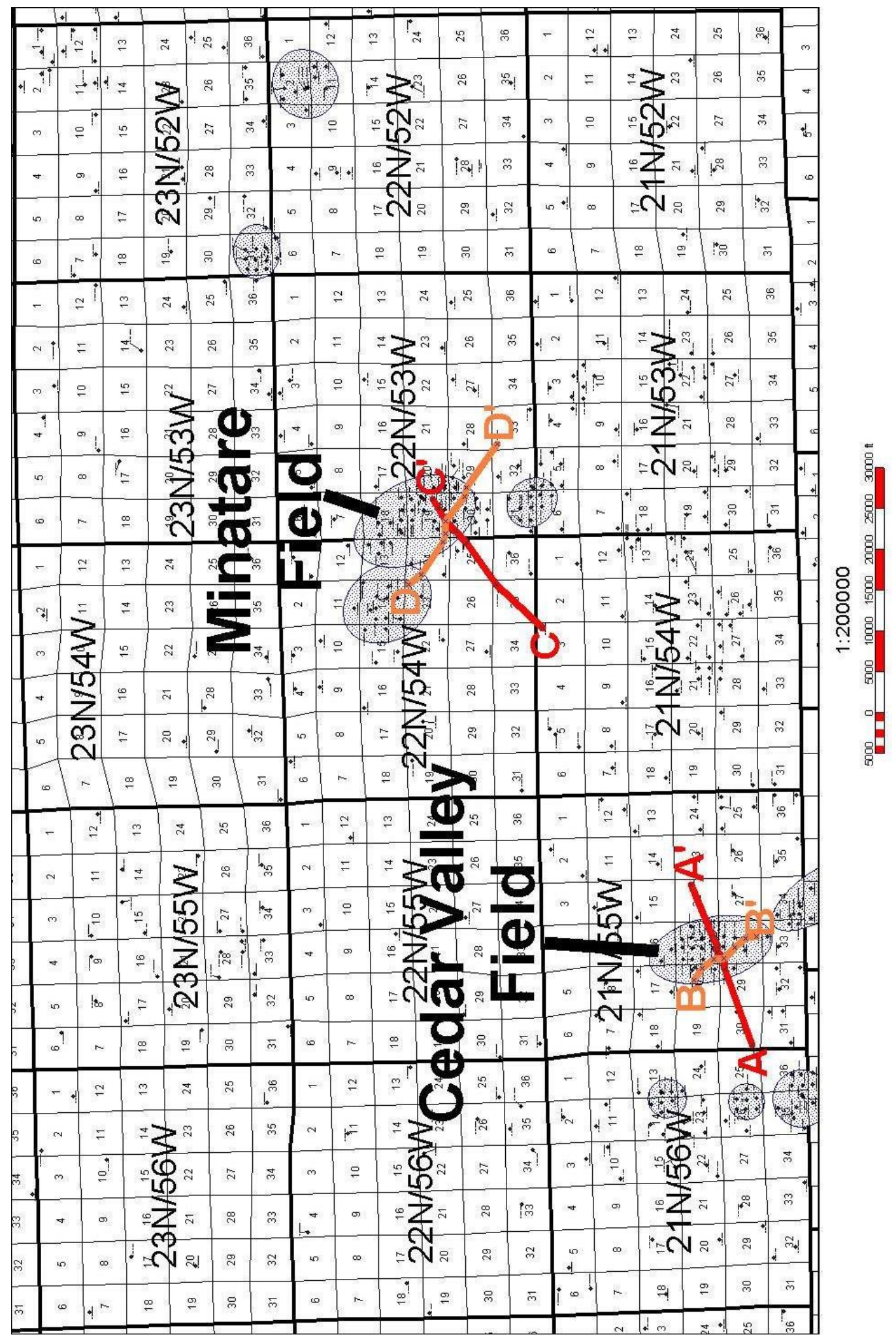

Figure 37: Base map showing locations of cross-sections in the study area. 
Table 1: Geological data from the presented cross-sections.

\begin{tabular}{|c|c|c|c|c|c|c|}
\hline WELL & GROSS J1 & NET J1 & MAX RES & INITIAL PROD & CORE DATA & DST \\
\hline $\begin{array}{c}\text { Buckley \#1 } \\
\text { 26-157-05235-0000 }\end{array}$ & $\begin{array}{l}24 \text { feet } \\
(7.3 \mathrm{~m})\end{array}$ & $\begin{array}{c}23 \text { feet } \\
(7 \mathrm{~m})\end{array}$ & 17 ohm-m & $\begin{array}{c}150 \mathrm{BO} \\
13 \mathrm{BWPD}\end{array}$ & $\begin{array}{l}\text { NONE RAN IN } \\
\text { HOLE }\end{array}$ & $\begin{array}{c}\text { gas in } 69 \\
\text { minutes }-1,850 \\
\text { feet }(563.9 \mathrm{~m}) \text { of } \\
\text { oil }-60 \mathrm{feet} \\
(18.3 \mathrm{~m}) \text { of } \\
\text { water-cut mud }\end{array}$ \\
\hline $\begin{array}{c}\text { Burkey \#1 } \\
\text { 26-157-05107-0000 }\end{array}$ & $\begin{array}{l}15 \text { feet } \\
(4.5 \mathrm{~m})\end{array}$ & $\begin{array}{c}8 \text { feet } \\
(2.4 \mathrm{~m})\end{array}$ & 12 ohm-m & DRY HOLE & $\begin{array}{c}\text { sandstone with } \\
\text { shale partings } \\
\text { capped by } 6 \text { feet } \\
(1.8 \mathrm{~m}) \text { of reworked } \\
\text { shale and tight } \\
\text { sandstone }\end{array}$ & $\begin{array}{l}\text { NONE RAN IN } \\
\text { HOLE }\end{array}$ \\
\hline $\begin{array}{c}\text { Coleman \#1 } \\
26-157-05219-0000\end{array}$ & $\begin{array}{l}18 \text { feet } \\
(5.5 \mathrm{~m})\end{array}$ & \begin{tabular}{|c|}
3 feet \\
$(0.9 \mathrm{~m})$ \\
\end{tabular} & 10 ohm-m & DRY HOLE & $\begin{array}{l}\text { NONE RAN IN } \\
\text { HOLE }\end{array}$ & $\begin{array}{c}\text { NONE RAN IN } \\
\text { HOLE }\end{array}$ \\
\hline $\begin{array}{c}\text { Everett \#1 } \\
\text { 26-157-05208-0000 }\end{array}$ & $\begin{array}{c}8 \mathrm{feet} \\
(2.4 \mathrm{~m})\end{array}$ & $\begin{array}{l}0 \text { feet } \\
(0 \mathrm{~m})\end{array}$ & 3 ohm-m & DRY HOLE & $\begin{array}{l}\text { NONE RAN IN } \\
\text { HOLE }\end{array}$ & $\begin{array}{l}\text { NONE RAN IN } \\
\text { HOLE }\end{array}$ \\
\hline $\begin{array}{c}\text { Groskopf \#1 } \\
26-157-05129-0000\end{array}$ & $\begin{array}{l}26 \text { feet } \\
(7.9 \mathrm{~m})\end{array}$ & $\begin{array}{l}22 \text { feet } \\
(6.7 \mathrm{~m})\end{array}$ & 60 ohm-m & $528 \mathrm{BO}$ & $\begin{array}{l}17 \text {-foot }(5.2 \mathrm{~m}) \text { fine- } \\
\text { grain sandstone with } \\
\text { a good stain } \\
\text { overlain by } \\
\text { reworked sandstone } \\
\text { and shale }\end{array}$ & $\begin{array}{c}\text { gas in } 70 \\
\text { minutes }-2,614 \\
\text { feet }(796.7 \mathrm{~m}) \text { of } \\
\text { oil }-146 \text { feet } \\
(44.5 \mathrm{~m}) \text { of mud- } \\
\& \text { oil-cut water }\end{array}$ \\
\hline $\begin{array}{c}\text { Groskopf \#2 } \\
26-157-05124-0000\end{array}$ & $\begin{array}{l}27 \text { feet } \\
(8.2 \mathrm{~m})\end{array}$ & $\begin{array}{l}25 \text { feet } \\
(7.6 \mathrm{~m})\end{array}$ & 37 ohm-m & $\begin{array}{l}284 \mathrm{BO} \\
7 \text { BWPD }\end{array}$ & $\begin{array}{c}\text { fine-grained } \\
\text { sandstone with a } \\
\text { good stain }\end{array}$ & $\begin{array}{c}\text { gas in } 65 \mathrm{~min}- \\
2285 \text { feet (696.5 } \\
\text { m) of oil }\end{array}$ \\
\hline $\begin{array}{c}\text { Hanlon \#1 } \\
26-157-05116-0000\end{array}$ & $\begin{array}{l}24 \text { feet } \\
(7.3 \mathrm{~m})\end{array}$ & $\begin{array}{l}21 \text { feet } \\
(6.4 \mathrm{~m})\end{array}$ & 62 ohm-m & $\begin{array}{c}208 \text { BO } \\
26 \% \text { WATER }\end{array}$ & $\begin{array}{c}3.5 \text { feet }(1.1 \mathrm{~m}) \text { of } \\
\text { slightly reworked } \\
\text { (top) sandstone with } \\
\text { a stain, } 4 \text { feet }(1.2 \\
\mathrm{m}) \text { tight, reworked } \\
\text { shale and } \\
\text { sandstone, } 10.5 \text { feet } \\
(3.2 \mathrm{~m}) \text { of fine- } \\
\text { grained slightly } \\
\text { friable sandstone } \\
\text { with a stain, } 2 \text { feet } \\
(0.6 \mathrm{~m}) \text { reworked } \\
\text { sandstone with a fair } \\
\text { stain, } 2 \text { feet }(0.6 \mathrm{~m}) \\
\text { shaley sandstone } \\
\text { with a trace stain, } 2 \\
\text { feet }(0.6 \mathrm{~m}) \text { shale }\end{array}$ & $\begin{array}{l}\text { gas in } 130 \\
\text { minutes - } 400 \\
\text { feet }(121.9 \mathrm{~m}) \text { of } \\
\text { oil }-230 \text { feet } \\
(70.1 \mathrm{~m}) \text { of oil- } \\
\text { cut, muddy } \\
\text { water }\end{array}$ \\
\hline
\end{tabular}




\begin{tabular}{|c|c|c|c|c|c|c|}
\hline WELL & GROSS J1 & NET J1 & MAX RES & INITIAL PROD & CORE DATA & DST \\
\hline $\begin{array}{c}\text { Hessler \#1 } \\
\text { 26-157-05240-0000 }\end{array}$ & $\begin{array}{l}16 \text { feet } \\
(4.9 \mathrm{~m})\end{array}$ & $\begin{array}{c}2 \text { feet } \\
(0.6 \mathrm{~m})\end{array}$ & 5 ohm-m & $\begin{array}{c}75 \mathrm{BO}^{*} \\
26.5 \mathrm{BWPD} \text { * } \\
\text { * from J2 }\end{array}$ & $\begin{array}{l}\text { NONE RAN IN } \\
\text { HOLE }\end{array}$ & $\begin{array}{c}75 \text { feet }(22.9 \mathrm{~m}) \\
\text { of mud-cut } \\
\text { water }\end{array}$ \\
\hline $\begin{array}{c}\text { Hickey \#1 } \\
\text { 26-157-05158-0000 }\end{array}$ & $\begin{array}{l}12 \text { feet } \\
(3.7 \mathrm{~m})\end{array}$ & \begin{tabular}{|c|}
6 feet \\
$(1.8 \mathrm{~m})$ \\
\end{tabular} & 40 ohm-m & NONE NOTED & $\begin{array}{l}\text { NONE RAN IN } \\
\text { HOLE }\end{array}$ & $\begin{array}{l}\text { NONE RAN IN } \\
\text { HOLE }\end{array}$ \\
\hline $\begin{array}{c}\text { Juergens \#1 } \\
26-157-21087-0000\end{array}$ & $\begin{array}{l}18 \text { feet } \\
(5.5 \mathrm{~m})\end{array}$ & \begin{tabular}{|l|}
14 feet \\
$(4.3 \mathrm{~m})$
\end{tabular} & 9 ohm-m & DRY HOLE & $\begin{array}{l}\text { NONE RAN IN } \\
\text { HOLE }\end{array}$ & $\begin{array}{l}\text { NONE RAN IN } \\
\text { HOLE }\end{array}$ \\
\hline $\begin{array}{c}\text { Kawaguchi \#1 } \\
\text { 26-157-21287-0000 }\end{array}$ & $\begin{array}{l}19 \text { feet } \\
(5.8 \mathrm{~m})\end{array}$ & $\begin{array}{c}8 \text { feet } \\
(2.4 \mathrm{~m})\end{array}$ & 8 ohm-m & DRY HOLE & $\begin{array}{l}\text { NONE RAN IN } \\
\text { HOLE }\end{array}$ & $\begin{array}{c}1,170 \text { feet } \\
(356.6 \mathrm{~m}) \text { of } \\
\text { water }\end{array}$ \\
\hline $\begin{array}{c}\text { Krumenacher \#1 } \\
26-157-21034-0000\end{array}$ & $\begin{array}{l}20 \text { feet } \\
(6.1 \mathrm{~m})\end{array}$ & \begin{tabular}{|l|}
12 feet \\
$(3.7 \mathrm{~m})$
\end{tabular} & 10 ohm-m & DRY HOLE & $\begin{array}{l}\text { NONE RAN IN } \\
\text { HOLE }\end{array}$ & $\begin{array}{l}\text { NONE RAN IN } \\
\text { HOLE }\end{array}$ \\
\hline $\begin{array}{c}\text { McGerr \#2 } \\
26-157-05156-0000\end{array}$ & $\begin{array}{l}20 \text { feet } \\
(6.1 \mathrm{~m})\end{array}$ & $\begin{array}{l}16 \text { feet } \\
(4.9 \mathrm{~m})\end{array}$ & 68 ohm-m & $28 \mathrm{BO}$ & $\begin{array}{l}6 \text { feet }(1.8 \mathrm{~m}) \text { of } \\
\text { stained friable } \\
\text { sandstone }\end{array}$ & $\begin{array}{c}\text { gas in } 120 \\
\text { minutes }-880 \\
\text { feet }(268.2 \mathrm{~m}) \text { of } \\
\text { oil }-110 \text { feet } \\
(33.5 \mathrm{~m}) \text { of } \\
\text { water }\end{array}$ \\
\hline $\begin{array}{c}\text { Pickering \#1 } \\
\text { 26-157-05239-0000 }\end{array}$ & $\begin{array}{l}28 \text { feet } \\
(8.5 \mathrm{~m})\end{array}$ & $\begin{array}{l}24 \text { feet } \\
(7.3 \mathrm{~m})\end{array}$ & 48 ohm-m & $\begin{array}{l}18.75 \mathrm{mcf} \\
150 \mathrm{BO} \\
9.5 \mathrm{BWPD}\end{array}$ & $\begin{array}{l}\text { tight sandstone with } \\
\text { good shows of oil }\end{array}$ & $\begin{array}{c}\text { gas in } 57 \\
\text { minutes }-1,778 \\
\text { feet }(541.9 \mathrm{~m}) \text { of } \\
\text { oil }-100 \text { feet } \\
\text { (30.5 m) of } \\
\text { water }\end{array}$ \\
\hline $\begin{array}{c}\text { Pickering/Stallboris } \\
\# 4 \\
26-157-21066-0001\end{array}$ & $\begin{array}{l}24 \text { feet } \\
(7.3 \mathrm{~m})\end{array}$ & $\begin{array}{l}17 \text { feet } \\
(5.2 \mathrm{~m})\end{array}$ & 27 ohm-m & $\begin{array}{c}2 \text { BO } \\
90 \text { BWPD }\end{array}$ & $\begin{array}{l}\text { NONE RAN IN } \\
\text { HOLE }\end{array}$ & $\begin{array}{c}450 \text { feet }(137.2 \\
\text { m) of oil }-30 \\
\text { feet }(9.1 \mathrm{~m}) \\
\text { mud-cut oil }-30 \\
\text { feet }(9.1 \mathrm{~m}) \text { oil } \\
\text { and gas-cut } \\
\text { mud }-60 \text { feet } \\
(18.3 \mathrm{~m}) \text { gas-cut } \\
\text { water - } 120 \text { feet } \\
\text { (36.6 m) of } \\
\text { water }\end{array}$ \\
\hline $\begin{array}{c}\text { Quindt \#1 } \\
\text { 26-157-21032-0000 }\end{array}$ & $\begin{array}{l}27 \text { feet } \\
(8.2 \mathrm{~m})\end{array}$ & $\begin{array}{l}21 \text { feet } \\
(6.4 \mathrm{~m})\end{array}$ & 27 ohm-m & $\begin{array}{c}33 \mathrm{BO} \\
48 \mathrm{BWPD}\end{array}$ & $\begin{array}{l}\text { NONE RAN IN } \\
\text { HOLE }\end{array}$ & $\begin{array}{c}1,117 \text { feet } \\
(340.5 \mathrm{~m}) \text { of oil - } \\
25 \text { feet }(7.6 \mathrm{~m}) \\
\text { of oil-cut mud }\end{array}$ \\
\hline $\begin{array}{c}\text { Rau \#2 } \\
\text { 26-157-05234-0000 }\end{array}$ & $\begin{array}{l}26 \text { feet } \\
(7.9 \mathrm{~m})\end{array}$ & $\begin{array}{l}21 \text { feet } \\
(6.4 \mathrm{~m})\end{array}$ & 35 ohm-m & $\begin{array}{c}162 \mathrm{BO} \\
162 \mathrm{BWPD}\end{array}$ & $\begin{array}{l}\text { NONE RAN IN } \\
\text { HOLE }\end{array}$ & $\begin{array}{c}\text { gas in } 40 \\
\text { minutes }-2,345 \\
\text { feet }(714.8 \mathrm{~m}) \text { of } \\
\text { oil }\end{array}$ \\
\hline $\begin{array}{c}\text { Rau \#3 } \\
\text { 26-157-05237-0000 }\end{array}$ & $\begin{array}{l}20 \text { feet } \\
(6.1 \mathrm{~m})\end{array}$ & \begin{tabular}{|l|}
18 feet \\
$(5.5 \mathrm{~m})$ \\
\end{tabular} & 10 ohm-m & DRY HOLE & $\begin{array}{c}\text { NONE RAN IN } \\
\text { HOLE }\end{array}$ & $\begin{array}{l}\text { NONE RAN IN } \\
\text { HOLE }\end{array}$ \\
\hline $\begin{array}{l}\text { Schaneman \#23-41 } \\
26-157-21242-0000\end{array}$ & $\begin{array}{l}17 \text { feet } \\
(5.2 \mathrm{~m})\end{array}$ & $\begin{array}{c}3 \text { feet } \\
(0.9 \mathrm{~m})\end{array}$ & 7 ohm-m & DRY HOLE & $\begin{array}{l}\text { NONE RAN IN } \\
\text { HOLE }\end{array}$ & $\begin{array}{l}\text { NONE RAN IN } \\
\text { HOLE }\end{array}$ \\
\hline
\end{tabular}




\begin{tabular}{|c|c|c|c|c|c|c|}
\hline WELL & GROSS J1 & NET J1 & MAX RES & INITIAL PROD & CORE DATA & DST \\
\hline $\begin{array}{c}\text { Schmidt - Kaufman } \\
\# 42-22 \\
26-157-21251-0000\end{array}$ & $\begin{array}{l}8 \text { feet } \\
(2.4 \mathrm{~m})\end{array}$ & $\begin{array}{c}2 \text { feet } \\
(0.6 \mathrm{~m})\end{array}$ & 8 ohm-m & DRY HOLE & $\begin{array}{l}\text { NONE RAN IN } \\
\text { HOLE }\end{array}$ & $\begin{array}{l}\text { NONE RAN IN } \\
\text { INTERVAL }\end{array}$ \\
\hline $\begin{array}{c}\text { Schubert \#1 } \\
\text { 26-157-05140-0000 }\end{array}$ & $\begin{array}{l}18 \text { feet } \\
(5.5 \mathrm{~m})\end{array}$ & $\begin{array}{c}8 \text { feet } \\
(2.4 \mathrm{~m})\end{array}$ & 72 ohm-m & $\begin{array}{c}76 \text { BO } \\
5 \% \text { WATER }\end{array}$ & $\begin{array}{c}0.25 \text { feet }(0.08 \mathrm{~m}) \\
\text { sandstone with a } \\
\text { stain,1.25 feet }(0.4 \\
\mathrm{m}) \text { reworked shale } \\
\text { and sandstone, } 1 \\
\text { foot }(0.3 \mathrm{~m}) \text { bleeding } \\
\text { oil sandstone, } 0.25 \\
\text { feet }(0.08 \mathrm{~m}) \\
\text { reworked shale and } \\
\text { sandstone, } 0.75 \text { feet } \\
(0.23 \mathrm{~m}) \text { sandstone, } \\
2.5 \text { feet }(0.76 \mathrm{~m}) \\
\text { stained sandstone } \\
\text { with poor p\&p, } 5 \text { feet } \\
(1.5 \mathrm{~m}) \text { sandstone } \\
\text { with fair } \mathrm{p} \& \mathrm{p}, 1 \text { foot } \\
(0.3 \mathrm{~m}) \text { hard } \\
\text { sandstone, } 1 \text { foot } \\
(0.3 \mathrm{~m}) \text { tight } \\
\text { reworked } \\
\text { sandstone, } 1 \text { foot } \\
(0.3 \mathrm{~m}) \text { shale }\end{array}$ & $\begin{array}{c}\text { gas in } 72 \\
\text { minutes - 1,270 } \\
\text { feet }(387 \mathrm{~m}) \text { of } \\
\text { "live, gassy, } \\
\text { greenish brown" } \\
\text { oil }-920 \text { feet } \\
(585.2 \mathrm{~m}) \text { of } \\
\text { water }\end{array}$ \\
\hline $\begin{array}{c}\text { Weiss \#1 } \\
\text { 26-157-05104-0000 }\end{array}$ & $\begin{array}{l}5 \text { feet } \\
(1.5 \mathrm{~m})\end{array}$ & \begin{tabular}{|c|}
3 feet \\
$(0.9 \mathrm{~m})$ \\
\end{tabular} & 23 ohm-m & DRY HOLE & $\begin{array}{c}\text { NONE RAN IN } \\
\text { HOLE }\end{array}$ & $\begin{array}{c}\text { NONE RAN IN } \\
\text { HOLE }\end{array}$ \\
\hline $\begin{array}{c}\text { Weiss \#1 } \\
\text { 26-157-21103-0000 }\end{array}$ & $\begin{array}{l}23 \text { feet } \\
(7 \mathrm{~m})\end{array}$ & $\begin{array}{c}6 \text { feet } \\
(1.8 \mathrm{~m}) \\
\end{array}$ & 13 ohm-m & DRY HOLE & $\begin{array}{l}\text { NONE RAN IN } \\
\text { HOLE }\end{array}$ & $\begin{array}{l}\text { NONE RAN IN } \\
\text { HOLE }\end{array}$ \\
\hline $\begin{array}{c}\text { Wilson \#1 } \\
\text { 26-157-05226-0000 }\end{array}$ & $\begin{array}{l}24 \text { feet } \\
(7.3 \mathrm{~m})\end{array}$ & $\begin{array}{l}14 \text { feet } \\
(4.3 \mathrm{~m})\end{array}$ & 12 ohm-m & DRY HOLE & $\begin{array}{l}7 \text { feet }(2.1 \mathrm{~m}) \text { of } \\
\text { tight sandstone, } 0.5 \\
\text { feet }(0.15 \mathrm{~m}) \text { of } \\
\text { shale, } 4.5 \text { feet }(1.4 \\
\mathrm{m}) \text { of sandstone } \\
\text { with good porosity } \\
\text { and permeability } \\
\text { and a good stain, } \\
0.25 \text { feet }(0.076 \mathrm{~m}) \\
\text { of shale, and } 7 \text { feet } \\
(2.1 \mathrm{~m}) \text { of wet } \\
\text { sandstone }\end{array}$ & $\begin{array}{c}90 \text { feet }(27.4 \mathrm{~m}) \\
\text { of oil }-90 \text { feet } \\
(27.4 \mathrm{~m}) \text { of hard } \\
\text { oil-cut mud - } \\
1,000 \text { feet } \\
(304.8 \mathrm{~m}) \text { of oil- } \\
\text { cut water - } \\
1,700 \text { feet } \\
(518.2 \mathrm{~m}) \text { of } \\
\text { slightly oil-cut } \\
\text { water }\end{array}$ \\
\hline $\begin{array}{c}\text { Yount \#5 } \\
26-157-05138-0000\end{array}$ & $\begin{array}{l}28 \text { feet } \\
(8.5 \mathrm{~m})\end{array}$ & \begin{tabular}{|l|}
25 feet \\
$(7.6 \mathrm{~m})$ \\
\end{tabular} & 47 ohm-m & NONE NOTED & $\begin{array}{l}\text { NONE RAN IN } \\
\text { HOLE }\end{array}$ & $\begin{array}{c}\text { NONE RAN IN } \\
\text { HOLE }\end{array}$ \\
\hline $\begin{array}{c}\text { Yount \#8 } \\
26-157-21290-0000\end{array}$ & $\begin{array}{l}22 \text { feet } \\
(6.7 \mathrm{~m})\end{array}$ & \begin{tabular}{|l|}
14 feet \\
$(4.3 \mathrm{~m})$
\end{tabular} & 63 ohm-m & $75 \mathrm{BO}$ & $\begin{array}{l}\text { NONE RAN IN } \\
\text { HOLE }\end{array}$ & $\begin{array}{c}\text { NONE RAN IN } \\
\text { HOLE }\end{array}$ \\
\hline $\begin{array}{c}\text { Yount \#9 } \\
26-157-21297-0000\end{array}$ & $\begin{array}{l}26 \text { feet } \\
(7.9 \mathrm{~m})\end{array}$ & $\begin{array}{l}16 \text { feet } \\
(4.9 \mathrm{~m})\end{array}$ & 35 ohm-m & $33 \mathrm{BO}$ & $\begin{array}{l}\text { NONE RAN IN } \\
\text { HOLE }\end{array}$ & $\begin{array}{l}\text { NONE RAN IN } \\
\text { HOLE }\end{array}$ \\
\hline
\end{tabular}


curve signatures and core data, the author used this previous work to make facies interpretations within Scotts Bluff Trend.

\section{CEDAR VALLEY}

Figures 38 and 39 show the southwest-to-northeast structural and stratigraphic cross-sections within the Cedar Valley field, respectively. Structurally, the field dips to the southwest. Stratigraphically, the reservoir pinches out in both an updip and downdip directions. Lack of production in these updip wells is related to changes in lithology while the downdip wells lack hydrocarbons because of both lithology and oil column placement.

Moving updip across the Cedar Valley field, all three of Exum and Harms' (1968) facies are observed. The Burkey \#1 (API \# 26-157-05107-0000) is interpreted to be the bar-margin facies due to the number of feet of sandstone in relation to the gross interval. Core data also shows how the J1 Sandstone unit is a mix of sandstone and shale much like described by Exum and Harms (1968).

The Groskopf \#2 (API \# 26-157-05124-0000), Groskopf \#1(API \# 26-157-051290000), Yount \#9 (API \# 26-157-21297-0000) and Yount \#8 (API \# 26-157-21290-0000) wells are indicative of the central-bar facies. This interpretation is again based upon the net sandstone to gross $\mathrm{J} 1$ unit relationship. The SP signatures in these wells tend to have a more "blocky" look to them. Also, the Groskopf wells have core data that supports this interpretation (Table 1).

On the northeastern fringes of Cedar Valley field lays the Schubert \#1 (API \# 26157-05140-0000). This well is interpreted to lie within the updip portions of the barmargin facies that surrounds the field. Net sandstone comprises $44 \%$ of the total gross 


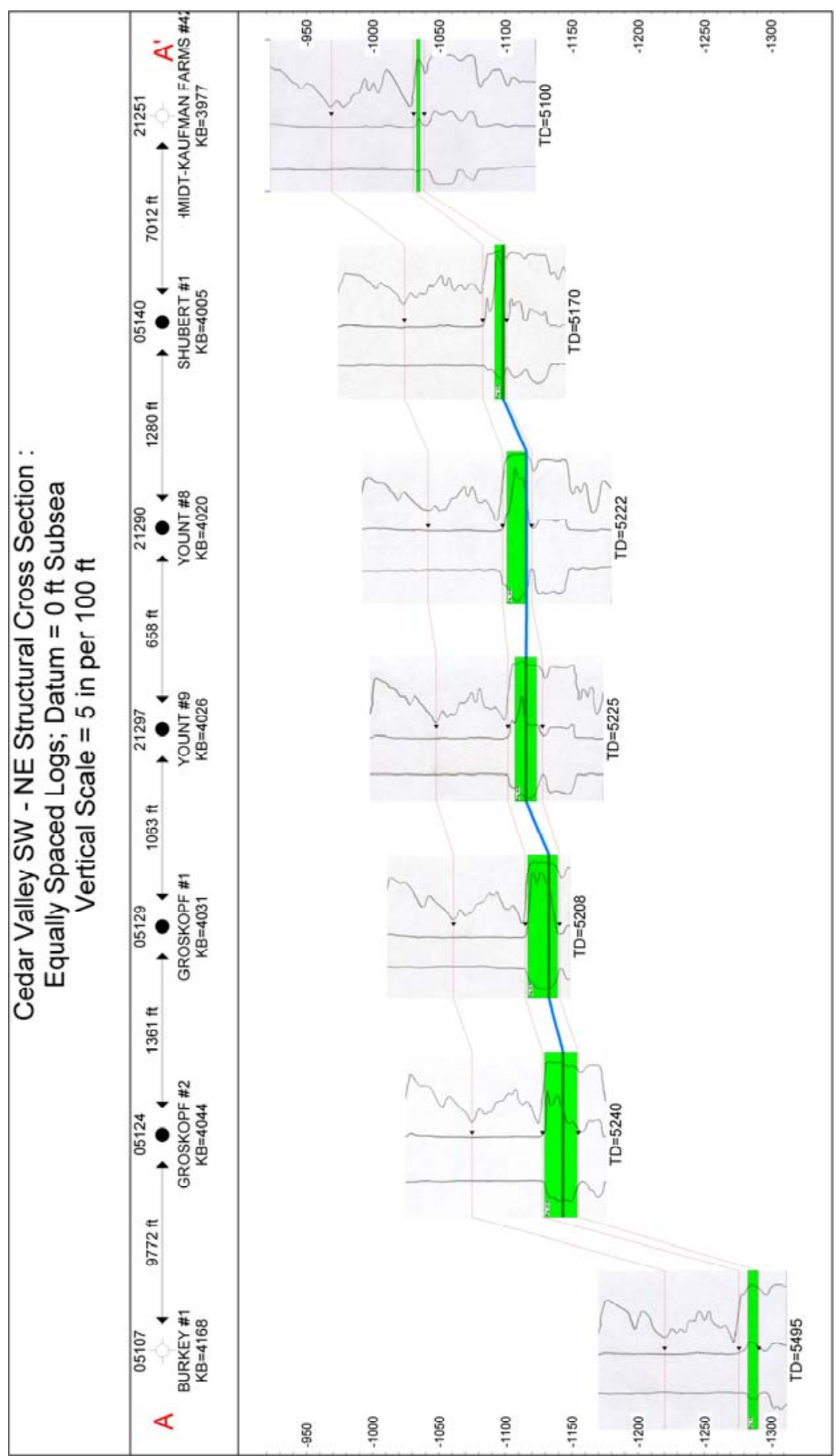

Figure 38: Structural cross-section parallel to regional dip across Cedar Valley Field. Each well log displays a SP, resistivity \& conductivity (left to right) curve. Huntsman Shale marker, J1 Sandstone top and base picks are shown by thin lines with arrow heads. Green boxes illustrate net J1 Sandstone thicks and blue line within the $\mathrm{J} 1$ interval represents an interpreted oil-water contact, where possible. 


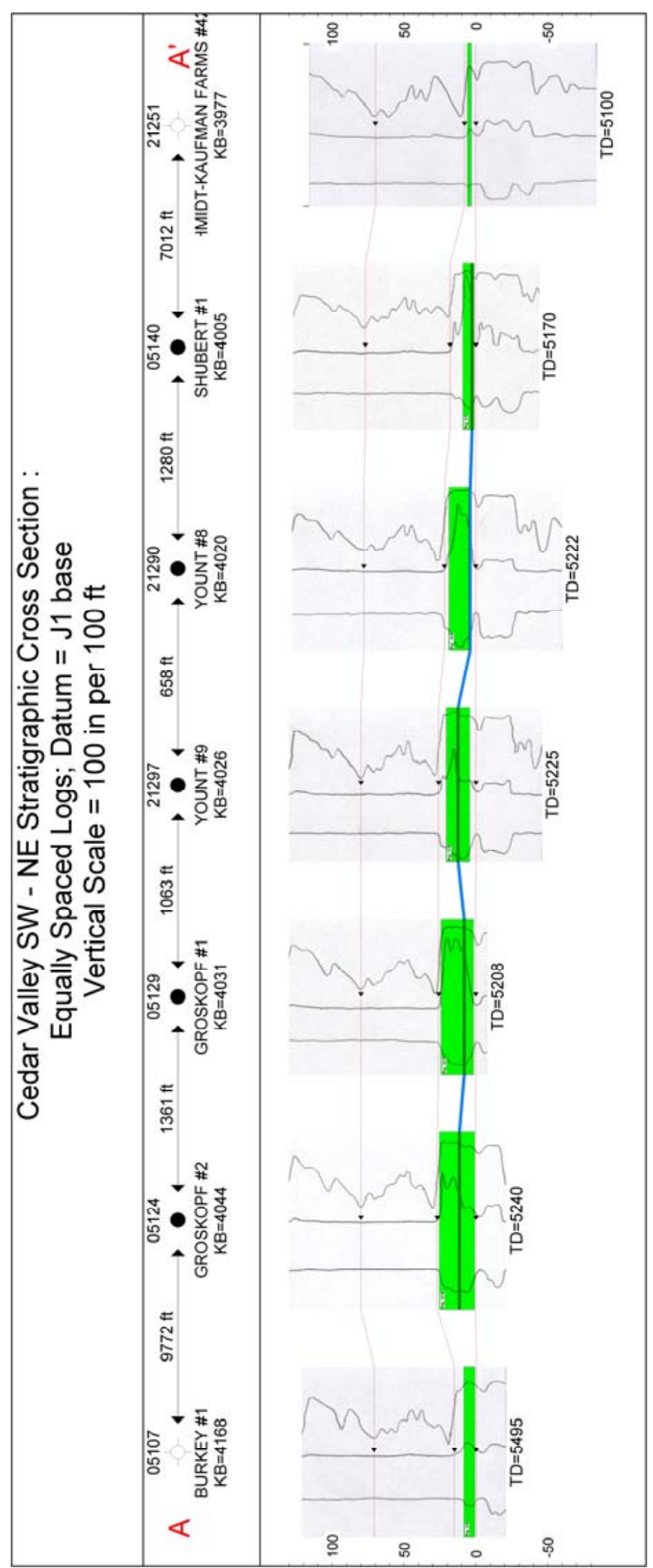

Figure 39: Stratigraphic cross-section parallel to regional dip across Cedar Valley Field. Each well log displays a SP, resistivity \& conductivity (left to right) curve. Huntsman Shale marker, J1 Sandstone top and base picks are shown by thin lines with arrow heads. Green boxes illustrate net J1 Sandstone thicks and blue line within the $\mathrm{J} 1$ interval represents an interpreted oil-water contact, where possible. 
interval, and core data shows a highly intermixed sandstone and shale lithology (Table 1).

Lastly the Schmidt - Kaufman Farms \# 42-22 (API \# 26-157-21251-0000) well is a representation of the inter-bar facies. Presence of sandstone has diminished to the point that shale is the overwhelming rock type. This is based upon interpretation of SP response.

Figures 40 and 41 show northwest to southeast structural and stratigraphic cross-sections within the Cedar Valley field, respectively. Structurally, these crosssections are dome-like. The northwest and southeast ends are structurally lower by approximately 10 feet $(3 \mathrm{~m})$. Stratigraphically, the net J1 Sandstone pinches out in both directions.

Moving in a southeastern direction across Cedar Valley field, the same sequence of facies is interpreted. The Hickey \#1 (API \# 26-157-05158-0000) represents the beginnings of the northern bar-margin facies away from the central-bar facies. Based upon SP response, the net sandstone portion of the gross unit is approximately $50 \%$. This response is correlative to Graham's (2000) MS-4 unit, such that the basal portion of the gross unit represents shale and coarsens upward into sandstone.

The McGerr \#2 (API \# 26-157-05156-0000), Yount \#5 (API \# 26-157-051380000), Groskopf \#1 (API \# 26-157-05129-0000) and Hanlon \#1 (API \# 26-157-051160000) wells are indicative of the central-bar facies. Like the central-bar facies in the southwest-to-northeast cross-section, these wells have "blocky" SP responses coupled with net sandstone being approximately equivalent to the gross thickness. Core data 


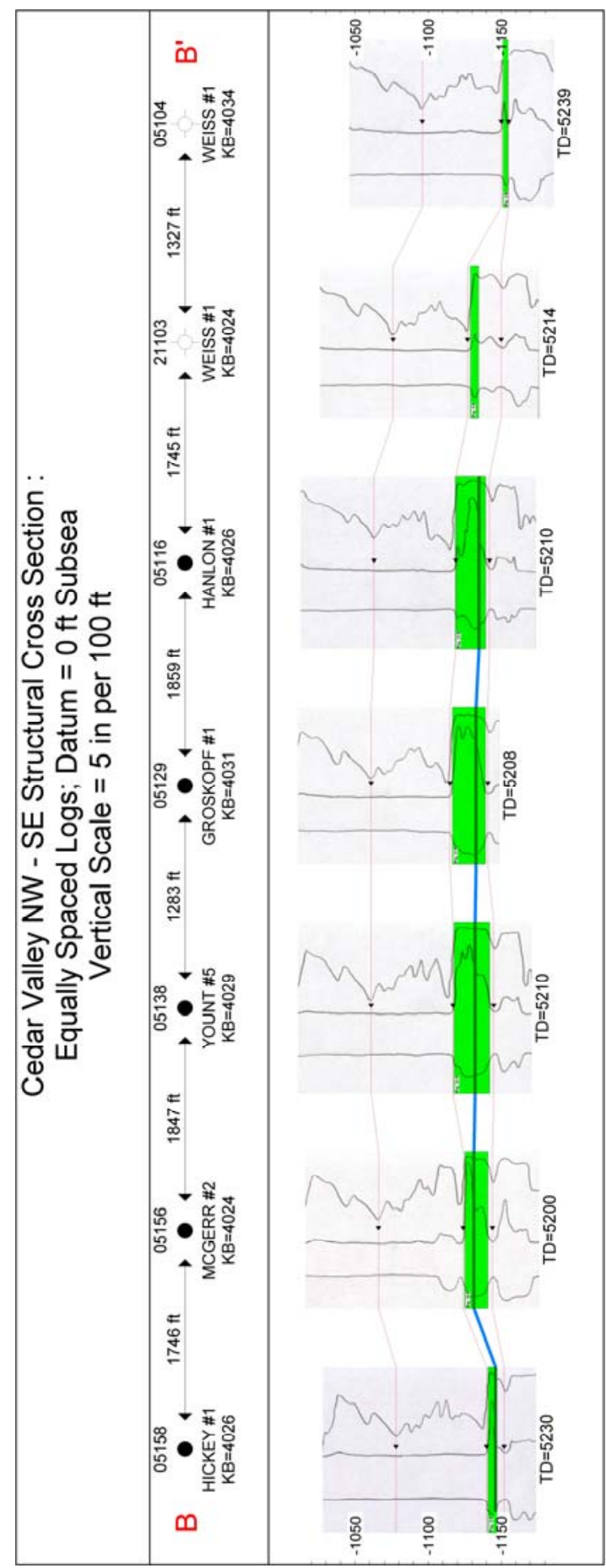

Figure 40: Structural cross-section parallel to regional strike across Cedar Valley Field. Each well log displays a SP, resistivity \& conductivity (left to right) curve. Huntsman Shale marker, J1 Sandstone top and base picks are shown by thin lines with arrow heads. Green boxes illustrate net J1 Sandstone thicks and blue line within the $\mathrm{J} 1$ interval represents an interpreted oil-water contact, where possible. 


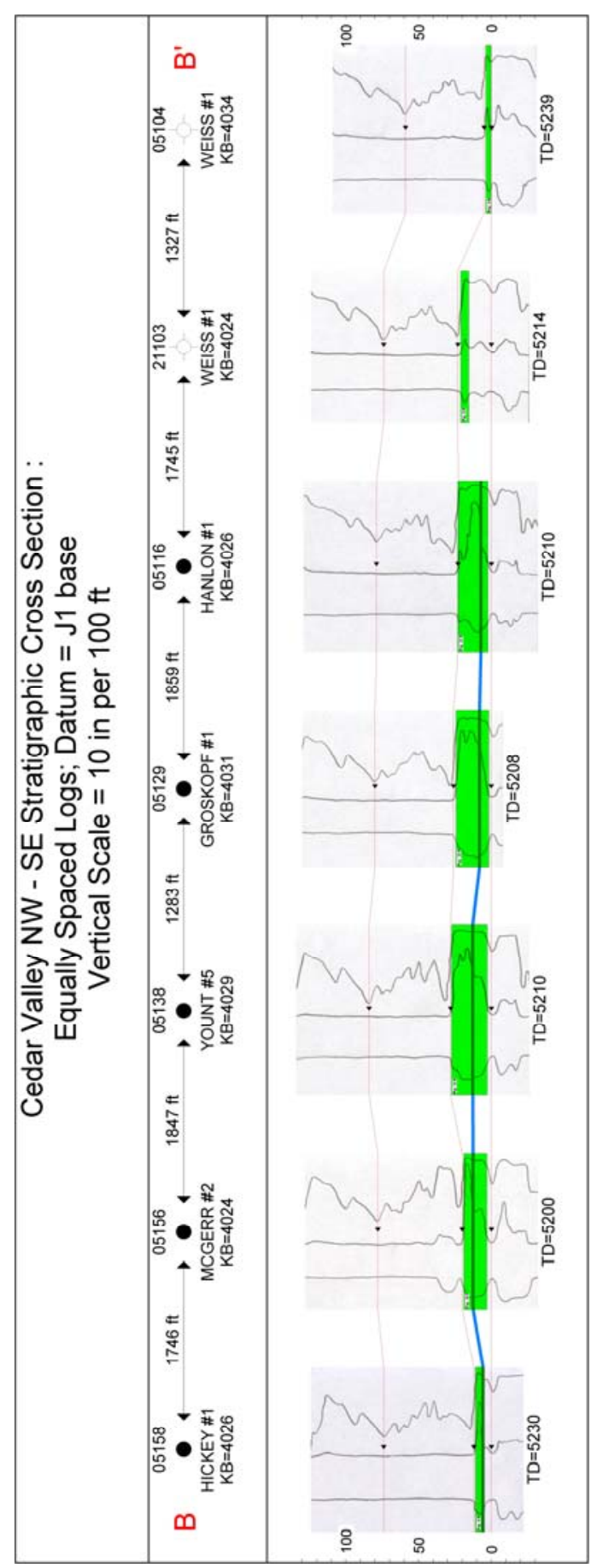

Figure 41: Stratigraphic cross-section parallel to regional strike across Cedar Valley Field. Each well log displays a SP, resistivity \& conductivity (left to right) curve. Huntsman Shale marker, J1 Sandstone top and base picks are shown by thin lines with arrow heads. Green boxes illustrate net J1 Sandstone thicks and blue line within the $\mathrm{J} 1$ interval represents an interpreted oil-water contact, where possible. 
from the Hanlon \#1 well indicates that this is the approximate southern facies boundary between the central-bar facies and the southern bar-margin facies.

On the southeastern fringes of Cedar Valley field lays the Weiss \#1 (API \# 26157-21103-0000). This well represents the southern bar-margin facies that surrounds the Cedar Valley field. Net sandstone has diminished to approximately $26 \%$ of the gross interval.

The southeastern inter-bar facies is represented in the Weiss \#1 well (API \# 26157-05104-0000). Interpretation of this facies is based upon SP log response, although the proportion of net sandstone to the gross interval is greater than the typical inter-bar facies. This is attributed to the extreme thinning in the southeast direction of the gross interval.

\section{MINATARE FIELD}

Figures 42 and 43 show the southwest to northeast structural and stratigraphic cross-sections within the Minatare field, respectively. Structurally, there is approximately 8 feet $(2.4 \mathrm{~m})$ of structural closure, based upon the top of the $\mathrm{J}$ sandstone, on the updip side of this cross-section. Again, in both the updip and downdip directions net J1 Sandstone laterally pinches out into siltstone/shale.

Across the Minatare field, in the structural dip direction, all three facies are seen again. The Everett \#1 (API \# 26-157-5208-0000) represents the inter-bar facies. SP and resistivity responses indicate that this well is comprised of a shale lithology. Unfortunately, no core data are available to support this interpretation. Due to spacing of the wells, no bar-margin facies is seen on the downdip side of Minatare. 


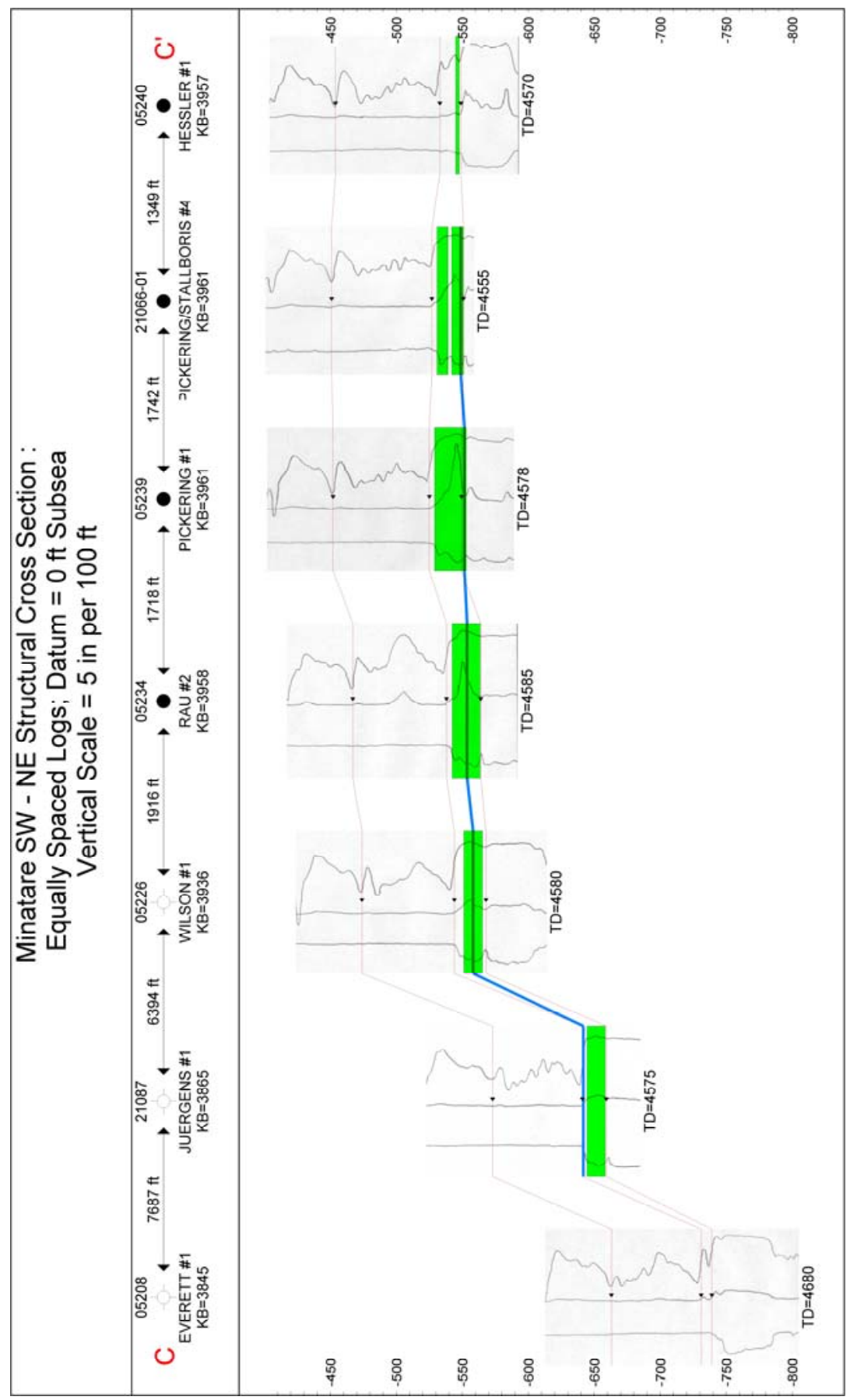

Figure 42: Structural cross-section parallel to regional dip across Minatare Field. Each well log displays a SP, resistivity \& conductivity (left to right) curve. Huntsman Shale marker, J1 Sandstone top and base picks are shown by thin lines with arrow heads. Green boxes illustrate net J1 Sandstone thicks and blue line within the $\mathrm{J} 1$ interval represents an interpreted oil-water contact, where possible. 


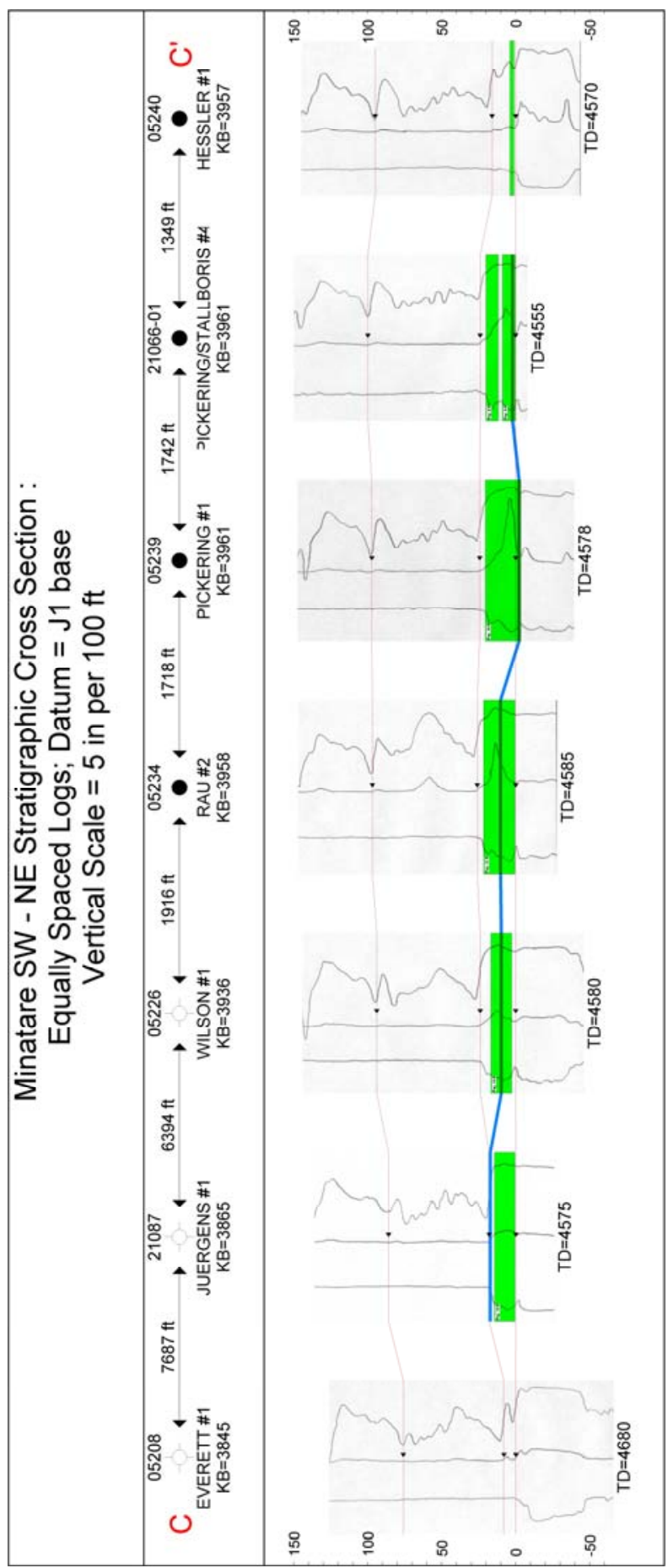

Figure 43: Stratigraphic cross-section parallel to regional dip across Minatare Field. Each well log displays a SP, resistivity \& conductivity (left to right) curve. Huntsman Shale marker, J1 Sandstone top and base picks are shown by thin lines with arrow heads. Green boxes illustrate net J1 Sandstone thicks and blue line within the $\mathrm{J} 1$ interval represents an interpreted oil-water contact, where possible. 
The Juergens \#1 (API \# 26-157-21087-0000), Wilson \#1 (API \# 26-157-052260000), Rau \#2 (API \# 26-157-05234-0000) Pickering \#1 (API \# 26-157-05239-0000) wells are interpreted to be the central-bar facies. Due to structural positioning the Juergens \#1 and Wilson \#1 are wet. Again, the SP responses are "blocky" in nature and net sandstone to gross interval proportions are relatively high.

On the updip edge of Minatare field lays the Pickering/Stallboris \#4 (API \# 26157-21066-0001). The northeastern bar-margin facies is interpreted to begin at this point. Although, the net sandstone portions are high, the SP response shows a transition into a mixed lithology.

The Hessler \#1 (API \# 26-157-05240-0000) well is indicative of the northeastern inter-bar facies that surrounds Minatare field. Net sandstone percentage drops to $12.5 \%$ of the gross interval. This well does produce but is attributed to the stratigraphically deeper J2 Sandstone.

Figures 44 and 45 show the northwest to southeast structural and stratigraphic cross-sections within the Minatare field, respectively. Structurally, there is an undulating nature to Minatare field, which has more relief (approximately 20 feet, $3 \mathrm{~m}$ ) than previously seen in the Cedar Valley northwest to southeast cross-sections. Like that of the dip cross-sections for Minatare field, net J1 Sandstone laterally interfingers into siltstone.

On the northwestern side of Minatare field, the Schaneman \#23-41 (API \# 26157-21242-0000) is interpreted to represent the inter-bar facies. No core data is available but the interpretation is based upon SP response and net sandstone to gross 




Figure 44: Structural cross-section parallel to regional strike across Minatare Field. Each well log displays a SP, resistivity \& conductivity (left to right) curve. Huntsman Shale marker, J1 Sandstone top and base picks are shown by thin lines with arrow heads. Green boxes illustrate net J1 Sandstone thicks and blue line within the $\mathrm{J} 1$ interval represents an interpreted oil-water contact, where possible. 


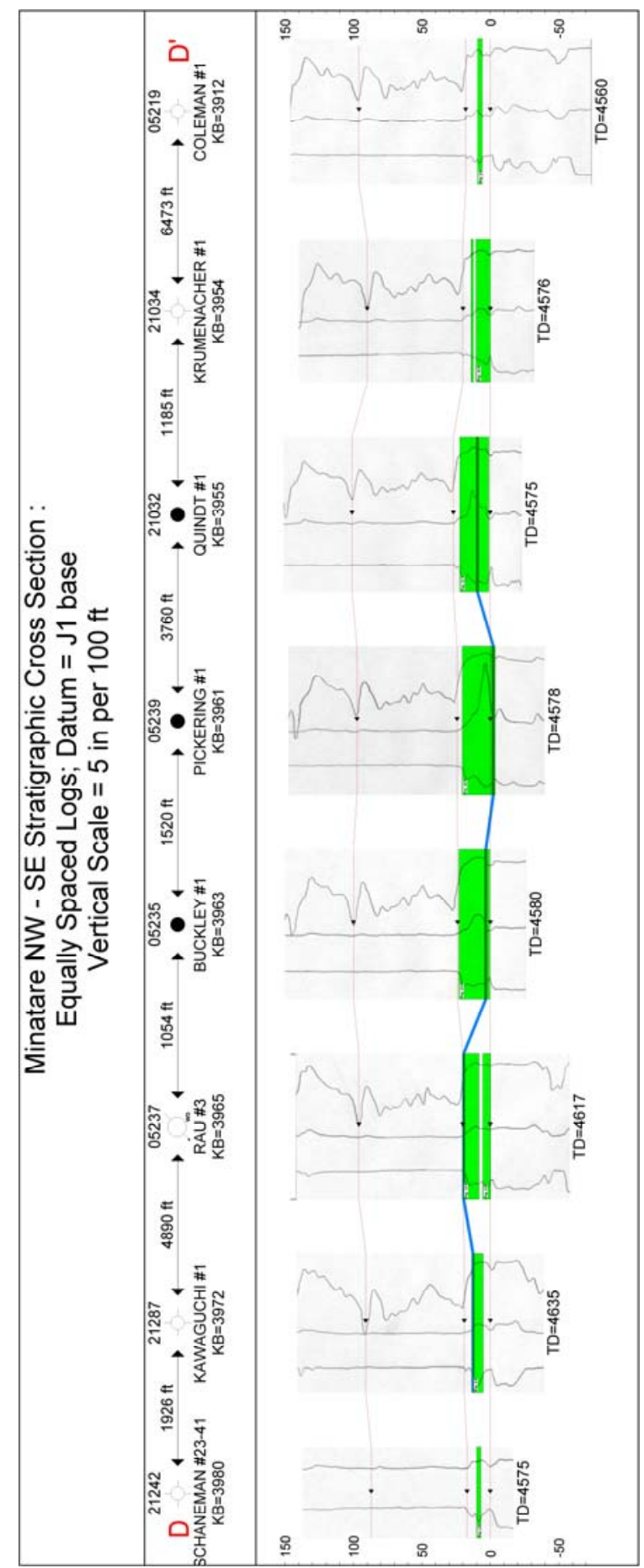

Figure 45: Stratigraphic cross-section parallel to regional strike across Minatare Field. Each well log displays a SP, resistivity \& conductivity (left to right) curve. Huntsman Shale marker, J1 Sandstone top and base picks are shown by thin lines with arrow heads. Green boxes illustrate net J1 Sandstone thicks and blue line within the $\mathrm{J} 1$ interval represents an interpreted oil-water contact, where possible. 
interval ratio. Net sandstone comprises $18 \%$ of the unit, with the remainder construed to be shale.

The Kawaguchi \#1 (API \# 26-157-21287-0000), Rau \#3 (API \# 26-157-052370000) symbolize the bar-margin facies on the northwestern extents of Minatare. Net sandstone to gross interval ratio is $42 \%$ within the Kawaguchi \#1 well, whereas $90 \%$ of the Rau \#3 well is net sandstone. Interpretation of the Rau \#3 to be bar-margin instead of central-bar facies is based upon the fact that the net sandstone is comprised of two intervals. This well is probably the very southern edge of this interpreted facies. Lack of production in these two wells is due to structural positioning and placement of the oil column.

The Buckley \#1 (API \# 26-157-05235-0000), Pickering \#1 (API \# 26-157-052390000) and Quindt \#1 (API \# 26-157-21032-0000) represent the central-bar facies within Minatare field. Once again, interpretation is based upon the "blocky" SP log responses and high net sandstone to gross interval ratios observed (Table 1).

Krumenacher \#1 (API \# 26-157-21034-0000) indicates the start of the southern bar-margin facies that surrounds Minatare. Like the Rau \#3 well, net sandstone is comprised of two intervals. Net sandstone to gross interval ratio is approximately $60 \%$ and SP response shows a fining upward sequence.

The Coleman \#1 (API \# 26-157-05219-0000) is indicative of the inter-bar facies on the southern extent of Minatare field. Net sandstone comprises $17 \%$ of the gross interval, while SP log response is interpreted to be mostly shale. 


\section{EXPLORATORY PREDICTORS}

Due to the thickness of the J1 Sandstone, use of seismic technology could possibly not be able to discriminate these beds. Thus some sort of exploration tool is needed in conjunction with isopach and structure mapping to evaluate potential new reservoirs. This chapter of the study tries to establish a predictor to where hydrocarbons could be potentially located.

\section{MAXIMUM RESISTIVITY - ALL WELLS}

Figure 46 portrays the map of maximum resistivity with approximately 500 wells, productive and non-productive alike. This map in essence gives a sense as to where hydrocarbons are known to be present (higher values of resistivity). All 10 of the oil fields in the study area have wells with resistivities in excess of $20 \mathrm{ohm}-\mathrm{m}$ while there are some producing wells with resistivities as low as 15 ohm-m.

At Minatare there is a north trend of high resistivities with a maximum of $48 \mathrm{ohm}$ m. On the updip side of this trend is an irregular fingering effect that coincides with the updip pinch out of J1 Sandstone (Figure 36). Between Minatare field and Highline and Mustang Canyon fields, resistivities reach a minimum of zero on the southwest border

of Highline field. Resistivities rise on the downdip edges of these two fields. Although both of these fields are smaller, the gradual increase in resistivity is observed leading updip to the producing wells.

In the heart of Cedar Valley field, resistivities have been documented at greater than $100 \mathrm{ohm}-\mathrm{m}$. Updip from these wells, resistivities diminish. Like at Minatare, this 


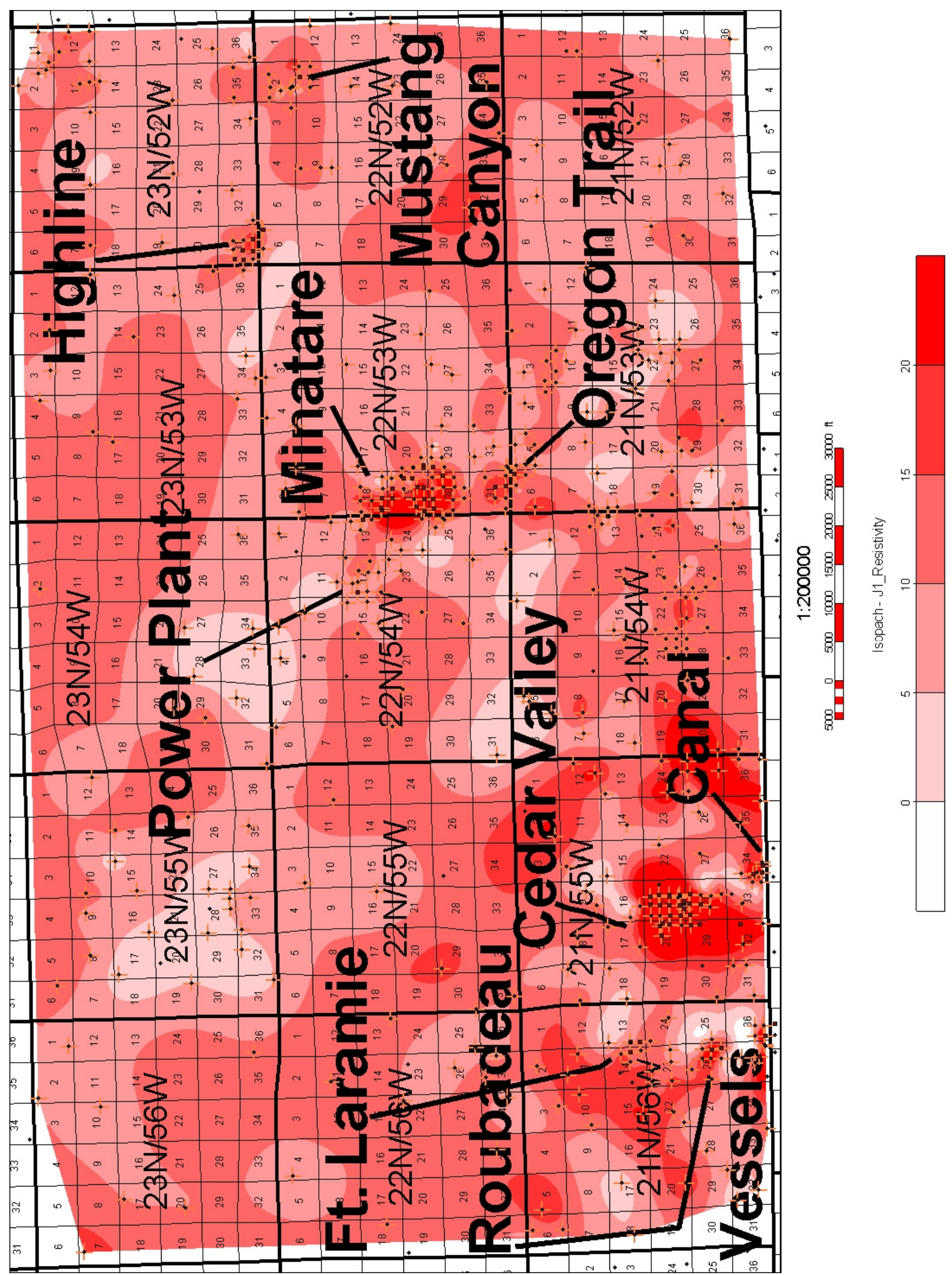

Figure 46: Isopach map of the maximum resistivity with all wells. Note that resistivities diminish on the updip side of oil fields. Contour interval 5 feet. 
drop in resistivity corresponds to the updip pinch out of net J1 Sandstone into siltstone (Figure 36).

South of Cedar Valley, resistivities plunge to near zero then begin to pick back up at Canal field. This change in resistivities between fields is a good indication that the two net J1 Sandstone bodies are not in lateral communication. This drop in resistivity also occurs to the west of Cedar Valley towards Fort Laramie, Roubadeau and Vessels fields. Between these three southwesternmost oil fields, resistivities plummet to zero, again indicating that they are separate producing sandstone bodies.

Comparison of maximum resistivities (Figure 46) to the $2^{\text {nd }}$ order residual map of the $\mathrm{J}$ structure (Figure 30 ) shows that most of the higher resistivities lie within the residual structural high. However there is one locale in the western sector of the study area that has higher resistivities located on the residual structural low. Section 5 of T21N - R56W has a well with 19 ohm-m of resistivity. Compared with producing wells in the study, this occurrence shows the potential for hydrocarbons on the residual low. Hence, not all hydrocarbons are restricted to this major central trend.

Comparison of these maximum resistivities (Figure 46) to the Huntsman Shale marker to J Sandstone isopach (Figure 31) depicts that most of the resistivities high enough to indicate hydrocarbon presence (approximately $>15 \mathrm{ohm}-\mathrm{m}$ ), are located within the Huntsman Shale thins. Nevertheless, there are two areas that contradict this. Within the large marine embayment that extends to the south (T23N - R53W) there are two wells with resistivities reaching 11 ohm-m. Although they do not meet the approximate threshold, one is led to believe that there would be higher resistivities in the area due to mapping. The second inconsistency is located northeast of Cedar 
Valley field where the smaller marine embayment protrudes to the southwest of the previously discussed main embayment. Located in section 2 of T21N - R55W, the Clark \#1 well (API\# 26-157-05198-0000) has a resistivity that reaches 20 ohm-m. These discrepancies are again attributed to the lack of stratigraphic well control in the two areas.

\section{MAXIMUM RESISTIVITY - NON PRODUCERS ONLY}

Mapping resistivities with all wells produces a map (Figure 46) that one would expect: high resistivity where the known oil fields are geographically situated and low resistivities elsewhere. Although this map shows where known hydrocarbons reside and can be compared to other maps, it does not give an indication as to where else in the study area hydrocarbons may be present and thus has little or no prediction value. By mapping resistivities without the producing wells (theoretically excluding the highest resistivities), one might expect to discover a relationship between the higher resistive dry holes (on the verge of being completable wells) and the known oil fields. Knowing this relationship would further reduce exploration risk.

Figure 47 is an isopach map of the maximum resistivity within the $\mathrm{J1}$ zone excluding the producing wells. The purpose of this map is to see if there is any correlation with the placement of the oil fields and whether or not they could be identified if only dry holes had been drilled.

As for Minatare, Power Plant and Oregon Trail fields, only Minatare would be found today if just dry holes were drilled; however, not all of the wells would be established from the mapping presented. Some of the producing oil wells in Minatare field lie within a lower resistivity zone that straddles a high on this map. Most likely the. 

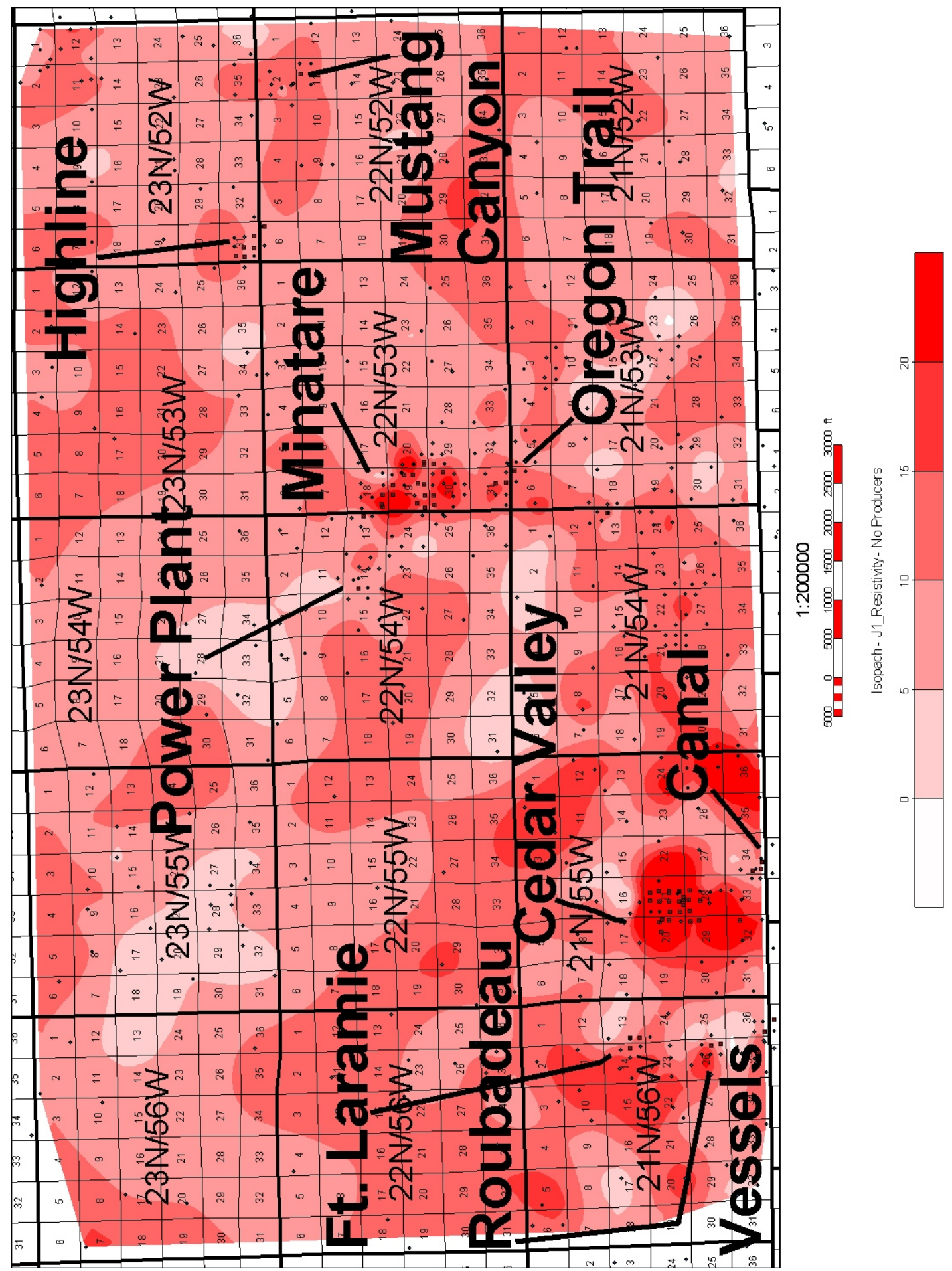

Figure 47: Isopach map of the maximum resistivity with non-productive wells only. Contour interval 5 feet. 
high between the wells would have been drilled. The northern portion of Minatare, sometimes referred to as North Minatare field (section 18 of T22N - R53W), would be the easiest to locate. Here the producing wells are downdip from dry holes with higher resistivity. Producing wells in Power Plant and Oregon Trail fields are located in fairways of lower resistivity.

The producing wells in the Highline field lie directly between two northwest-tosoutheast trends of dry holes. This field could possibly be found today with an optimistic exploration program. The problem would be that the producing wells are those with higher net sandstone values, and thus a contour of the net J1 Sandstone without the producers would look different (Figure 48). The thickness trend would not be present where the producing wells are situated, but rather to the northwest and southeast. Oil fields of this nature give hope for future exploratory drilling in the area.

In the southwest portion of the study area, Cedar Valley would be the only oil field of the five to be located. Again noticeable changes in resistivity separate the oil fields. Fort Laramie is positioned updip of a higher-resistivity trend. The two producing wells of Roubadeau field are surrounded by dry holes on three of four sides, only one offset away, and a zero trend in resistivity on the fourth. As for Vessels and Canal fields, they both lie in lower-resistivity trends.

A composite of the net J1 Sandstone (biased) and maximum resistivity (nonproducers only) is shown in Figure 49. This map exhibits a few areas with nonproductive wells, with elevated deep-induction readings, in close proximity to $\mathrm{J} 1$ Sandstone development. Of special note on this map are the high resistivities 


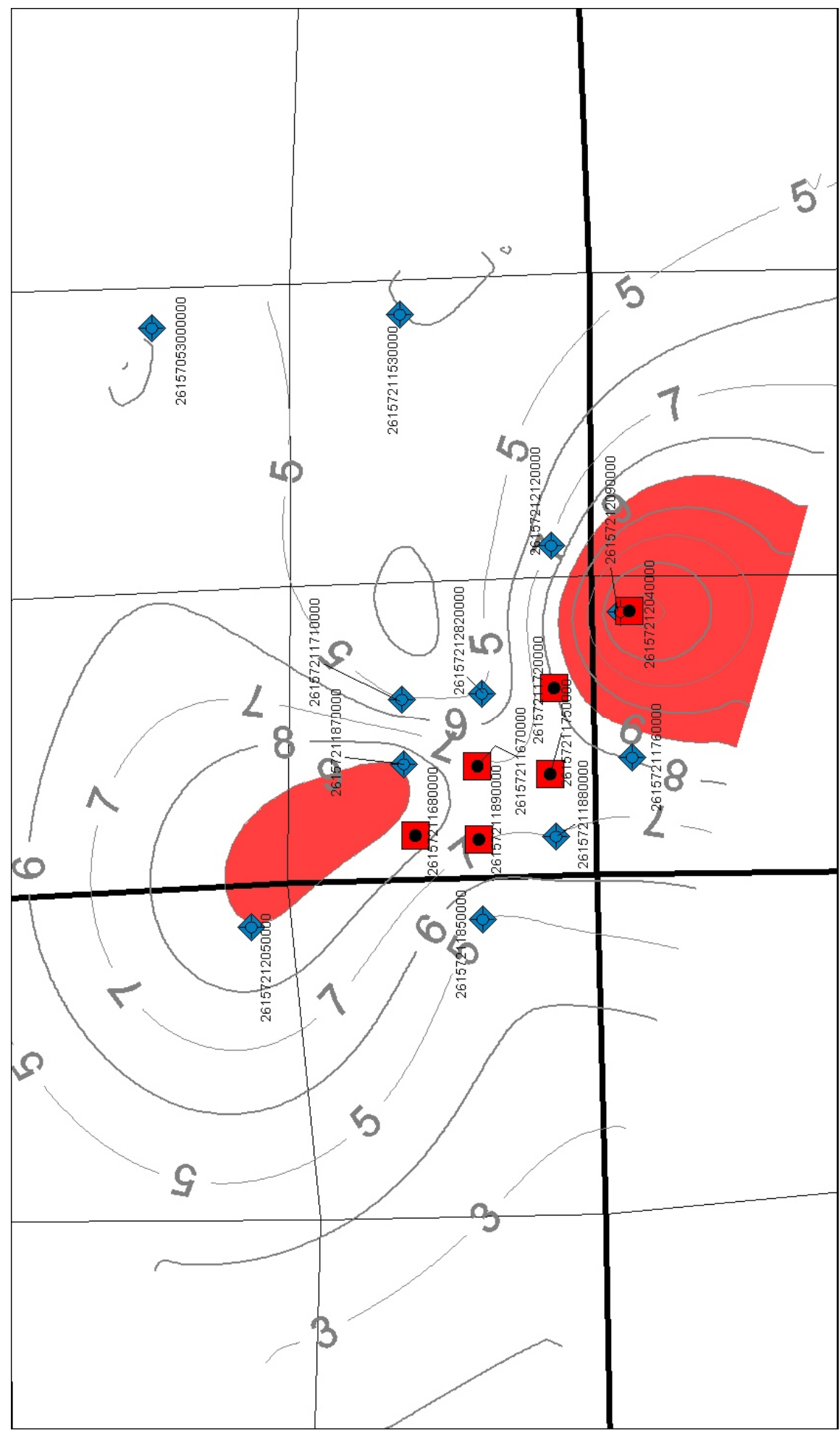

:

Figure 48: Highline field's net J1 Sandstone without the producers. Contour Interval 1 foot. 


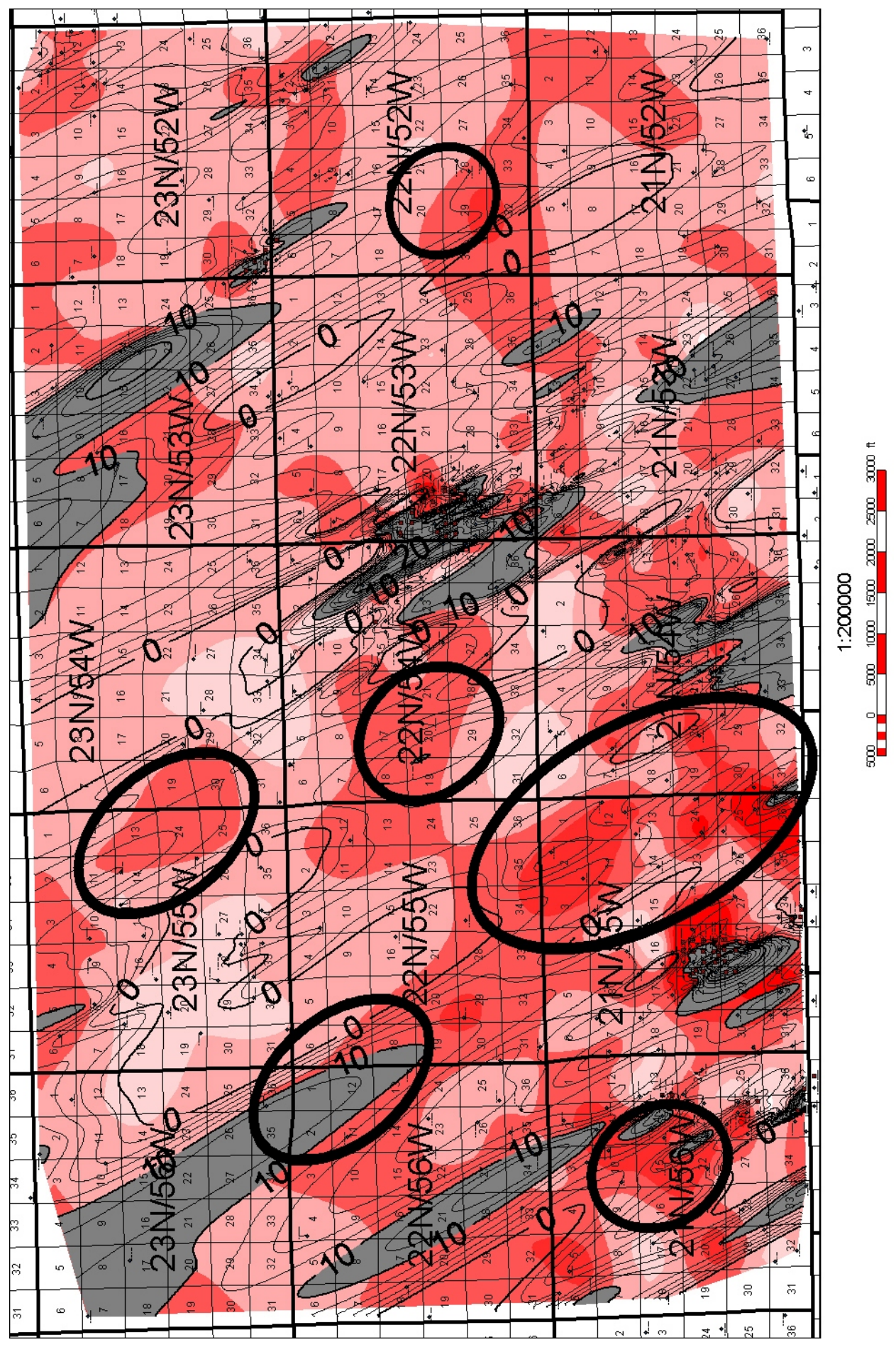

Figure 49: Isopach map of the maximum resistivity with non-productive wells only (Contour Interval 5 feet). It is overlain by the net J1 Sandstone isopach with geologic bias (Contour interval 2 feet). Circles show prospective areas of exploration. 
straddling the T21N - R54 \& R55W division. Located here is an area with greater than 20 ohm-m, but no known producing wells.

Located in section 25 of T21N - R55W are the Jerger \#1 (26-157-05126-0000, NENE) and the Stricker \#25-34 (26-157-21245-0000, SWSE) wells. The Jerger \#1 has 6 feet $(1.8 \mathrm{~m})$ of net $\mathrm{J1}$ Sandstone and a maximum resistivity reading of $36 \mathrm{ohm}-\mathrm{m}$. A slight spotted stain was noted in a core description. The Stricker \#25-34 well has 4 feet $(1.2 \mathrm{~m})$ of net $\mathrm{J} 1$ Sandstone present with a resistivity reading of $40 \mathrm{ohm}-\mathrm{m}$. To the northeast of these wells the net J1 Sandstone reaches a maximum thickness of 8 feet $(2.4 \mathrm{~m})$. Areas such as this have a high potential of future development.

A similar area of high potential is located in the northeast sector of T21N R55W. Situated in section 2, is the Clark \#1 well (26-157-05198-0000, SWSW). Just updip from an area with no net $\mathrm{J1}$ Sandstone, this well has 3 feet $(0.9 \mathrm{~m})$ of net $\mathrm{J1}$ Sandstone accompanied by $20 \mathrm{ohm}-\mathrm{m}$ of resistivity. This interval was cored and shows fine-grained sandstone with fair porosity and permeability. A well site located updip would perhaps discover thicker, producible J1 Sandstone.

A third possible area for future exploration is downdip of the Fort Laramie field. Like Highline field, Fort Laramie (section 15 of T21N - R56W) seems to be enclosed by dry holes. Northwest expansion of the net J1 Sandstone pod extending from the Ewing \#1 well (26-157-05383-0000, NWSW section 23, T21N - R56W) could give rise to further development. This would be updip from the Dwight Ewing \#1 well (26-15705175-0000, SESW, section 15, T T21N - R56W), which has a higher resistivity of 21 ohm-m. 
Other areas of interest include the northeast sector of T22N - R56W where a net J1 Sandstone pod extends to the southeast in the study area. This area is surrounded by mid-range resistivity values and is downdip of a locale lacking J1 Sandstone development. Another area similar to this is west of the Power Plant field, located around section 20 of T22N - R54W. North of this point is a sixth area, between two regions with no net $\mathrm{J1}$ Sandstone accumulation, with mid-range resistivities and a southeastward trending net J1 Sandstone pod. Finally, to the south of Highline field around section 20 of $\mathrm{T} 22 \mathrm{~N}-\mathrm{R} 52 \mathrm{~W}$ is an additional possible area of interest, similar to those discussed above. 


\section{CONCLUSIONS}

The $\mathrm{J}$ Sandstone has long been known as a reservoir rock in the Denver basin. Oil production within the Scotts Bluff Trend has been limited to mostly the J1 Sandstone interval. Drilling in the study area has continued intermittently from 1945 until as recently as 1998, and 10 oil fields with associated gas production have been discovered to date.

The purpose of this study was three-fold. First it was to be determined if there is any structural control upon the distribution of oil fields in the study area. Secondly, a more concise picture of the $\mathrm{J} 1$ sand geometry and depositional environment was to be established. Lastly, an exploration tool using resistivity data was to be evaluated. These objectives were achieved through careful examination of approximately 500 geophysical well logs and the subsequent interpretation of this data by way of generated maps and cross-sections.

Structural analysis of the Scotts Bluff Trend was completed through structure and residual mapping along with field-scale cross-sections. Structurally this area is relatively monoclinal in nature and regional dip is to the southwest at approximately 1.2 degrees (Figure 25). Structural downdip "nosing" is associated with most of the known oil fields and extends across the study area. Updip structural closures were observed in six of the 10 fields (Figures 26-28).

Residual mapping was implemented in order to remove present-day local structural elements. From the second-order residual map of the J Sandstone structure, the Scotts Bluff Trend is interpreted to be situated on a residual high. Silverman (1988) 
inferred that oil production is restricted to this trend and this residual map demonstrates the geographical extent of the Scotts Bluff structural Trend.

All of the fields are in some way associated with the residual high. Some lie directly on the high, whereas others are situated along the edges. Oil fields with structural closure on their updip edges are situated near the boundaries of this apparent residual high. For instance, the structural closure of Minatare field is positioned to the southwest of the relative residual low, northeast of the field. Alternatively, Cedar Valley has no updip structural closure and its location coincides with the main portion of the residual high in the study area.

A structural cross-section across the Minatare field in the regional dip direction gives insight into what creates this residual high. This cross-section shows eight-foot updip structural closure on the field. The net sand thickness reveals that the sandstone thins updip, while the shale thickens. Due to compaction contrasts between sandstone and shale, differential compaction has created a drape effect here. This drape effect coincides with the relative residual low on the updip side of Minatare field.

Stratigraphic analysis of the J1 Sandstone was completed through isopach mapping the overlying Huntsman Shale and the $\mathrm{J} 1$ deposits and understanding their relationship. The overlying Huntsman Shale isopach serves as a proxy for basin bathymetry at the time of deposition of $\mathrm{J} 1$ sand. The shale is relatively thicker to the north and thinner to the south. Comparison of relative shale thins and thicks to known oil fields reveal an inverse relationship. Around the oil fields, the Huntsman Shale is relatively thin, is interpreted to be a result of the lack of accommodation space due to 
sand deposition below and shallow waters above. Between fields, shale thickening represents the marine embayments present between the J1 Sandstone accumulations.

Based on previous studies by other authors and the present distribution of producing oil wells, a northwest-to-southeast orientation was used to bias contouring of the $\mathrm{J} 1$ isopach. These $\mathrm{J} 1$ Sandstone deposits are interpreted as marine bars because of their elongated orientation, and because these bars laterally interfinger with less permeable siltstone in all directions. This interfingering is evident by the facies changes observed in the field-scale cross-sections. Oil production from the J1 Sandstone is limited to the central-bar and bar-margin facies. Structurally low facies, however, will tend to be wet.

Assessment of a hydrocarbon predictor was completed through resistivity mapping. It was hoped that mapping with and without producing wells could show a relationship between known oil fields and updip dry-hole resistivity highs. Unfortunately, updip resistivities diminish with J1 Sandstone thinning. Hence this hypothesis is null. No relationship was found between the known oil fields and distribution of elevated resistivities in dry holes. Nevertheless, these resistivity maps can still be used in a more straight-forward manner with regards to prospecting. Comparison to the $2^{\text {nd }}$ order residual map of the $\mathrm{J}$ structure and Huntsman Shale isopach, reveals that higher resistivities are located within this residual high and where the shale thins (underlying sand thick).

$\mathrm{J} 1$ isopach mapping coupled with the maximum resistivity (without producing wells) identifies seven potential locations of interest for future drilling. These areas tend to be positioned where resistivities are slightly elevated coupled with J1 Sandstone 
thicks. Figure 50 reveals this same map with the residual structural high outlined in orange. Using this map to optimally pick prospects, the two northwesterly-most prospects would have the highest risk due to residing outside of the residual high. The southwest-most prospect is situated on the edge of the residual high and would have a higher associated risk than the prospects within the residual high. The four prospect areas that reside within the residual high have the lowest risk because the residual high is the zone where oil has migrated through the area updip. The prospect to the northeast has the least well control of the four, and would have the greatest risk of the group. The other three prospects that lie on the residual high are between Minatare and Cedar Valley fields and have suitable well control. Therefore, these would be the best candidates for further evaluation and possible drilling. 


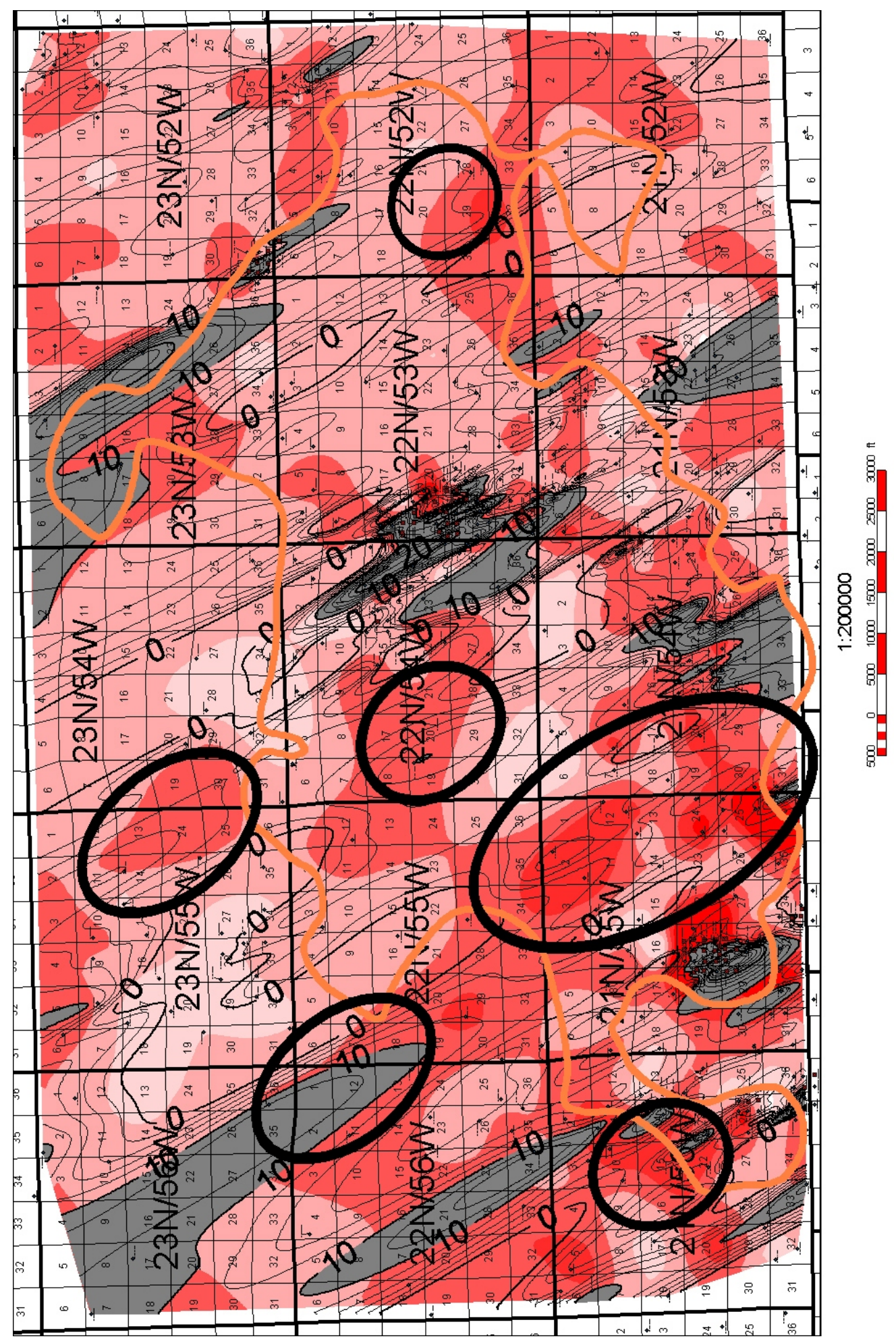

Figure 50: Isopach map of the maximum resistivity with non-productive wells only (Contour Interval 5 feet). It is overlain by the net J1 Sandstone isopach with geologic bias (Contour interval 2 feet). Circles show prospective areas of exploration and the residual high is outlined in orange. 


\section{REFERENCES}

Blakey, E.S., 1985, Oil on Their Shoes - Petroleum Geology to 1918: AAPG,

Tulsa, 192p.

Clark, B.A., 1978, Stratigraphy of the Lower Cretaceous J Sandstone, Boulder County, Colorado: A Deltaic Model, in Pruit, J.D., and Coffin, P.E., eds., field Conference: Rocky Mtn. Assoc. Geologists, p. 237-244

Clayton, J.L., and P.J. Swetland, 1980, Petroleum Generation and Migration in Denver Basin: AAPG Bulletin, v. 64, p. 1613-1633

Exum, F.A., and J.C. Harms, 1968, Comparison of Marine-bar with Valley-fill Stratigraphic Traps, Western Nebraska: AAPG Bulletin, v. 52, p. 1851-1868

Graham, J.P., 2000, Revised Stratigraphy, Depositional Systems, and Hydrocarbon Exploration Potential for the Lower Cretaceous Muddy Sandstone, Northern Denver Basin: AAPG Bulletin, v. 84, p. 183-209

Silverman, M.R., 1988, Petroleum Geology, Paleotectonics, and Sedimentation of the Scotts Bluff Trend, Northeastern Denver Basin, The Mountain Geologist, v. 25, no. 3 , p. $87-101$

Sonnenberg, S.A., and Weimer, R.J., 1981, Tectonics, Sedimentation, and Petroleum Potential, Northern Denver Basin, Colorado, Wyoming, and Nebraska: Colorado School of Mines Quarterly, v. 76, p. 1-45

Tweto, O., 1980, Summary of Laramide Orogeny in Colorado, in Kent, H.C., and Porter, K.W., eds., Colorado geology: Rocky Mtn. Assoc. Geologists, p. 129-134 


\section{APPENDIX}

\begin{tabular}{|c|c|c|c|c|c|c|c|c|}
\hline WELL ID & OPERATOR & $\begin{array}{c}\text { KB } \\
\text { ELEV }\end{array}$ & $\begin{array}{c}\text { TOP J } \\
\text { SUBSEA }\end{array}$ & $\begin{array}{l}\text { BASE J1 } \\
\text { SUBSEA }\end{array}$ & \begin{tabular}{|c|} 
J1 NET \\
THICKNESS
\end{tabular} & $\begin{array}{c}\text { INTERVAL } \\
\text { HUNTSMAN } \\
\text { SHALE } \\
\text { MARKER to } \\
\text { TOP OF J }\end{array}$ & \begin{tabular}{|c|} 
MAX \\
RESISTIVITY \\
WITHIN J1 \\
INTERVAL
\end{tabular} & TD \\
\hline 26123054680000 & VESSELS JR & 3847 & -415 & -431 & 5 & 58 & 12 & 4379 \\
\hline 26123054720000 & TOLTEK DRLG CO & 3944 & -327 & -343 & 4 & 63 & 11 & 4390 \\
\hline 26123054760000 & VESSELS JR & 3949 & -337 & -351 & 3 & 59 & 8 & 4373 \\
\hline 26123054860000 & VESSELS JR & 4216 & -168 & -180 & 5 & 65 & 9 & 4491 \\
\hline 26123054890000 & VESSELS JR & 4376 & -128 & -144 & 5 & 62 & 11 & 4590 \\
\hline 26123054910000 & VESSELS JR & 4191 & -194 & -209 & 5 & 63 & 13 & 4460 \\
\hline 26123054920000 & VESSELS JR & 4374 & -116 & -129 & 9 & 67 & 13 & 4561 \\
\hline 26123054930000 & VESSELS JR & 4281 & -108 & -124 & 10 & 63 & 13 & 4501 \\
\hline 26123054940000 & SUN OIL CO & 4295 & -115 & -132 & 12 & & 16 & 4490 \\
\hline 26123054960000 & THOMPSON & 4370 & -130 & -139 & 8 & 64 & 15 & 4584 \\
\hline 26123054990000 & REGAL DRLG CO & 4265 & -101 & -106 & 2 & 90 & 5 & 4418 \\
\hline 26123055000000 & SINCLAIR OIL \& GAS C & 4470 & -98 & -115 & 10 & 72 & 11 & 4642 \\
\hline 26123055060000 & TOLTEK DRLG CO & 4469 & -79 & -93 & 8 & 74 & 7 & 4653 \\
\hline 26123055120000 & REGAL DRLG CO & 4400 & 48 & 41 & 3 & 77 & 7 & 4433 \\
\hline 26123055150000 & VESSELS JR & 4412 & 48 & 36 & 6 & 74 & 12 & 4461 \\
\hline 26123055160000 & VESSELS JR & 4436 & 12 & -4 & 9 & 74 & 8 & 4510 \\
\hline 26123055180000 & JORDAN JR & 4442 & 85 & 69 & 9 & 83 & 17 & 4412 \\
\hline 26123055230000 & JORDAN JR & 4453 & 86 & 73 & 8 & 77 & 14 & 4435 \\
\hline 26123055240000 & CURRENTLY UNASSIGNED & 4461 & 83 & 74 & 4 & 77 & 3 & 4425 \\
\hline 26123055250000 & BALDERSON DRLG CO & 4401 & 108 & 103 & 2 & 84 & 8 & 4404 \\
\hline 26123055260000 & TEXOTA OIL CO & 4410 & 92 & 86 & 3 & 82 & 2 & 4400 \\
\hline 26123055270000 & JORDAN JR & 4386 & 87 & 78 & 3 & 79 & 10 & 4352 \\
\hline 26123055780000 & VESSELS JR & 4215 & -111 & -128 & 13 & 62 & 12 & 4400 \\
\hline 26123055870000 & VESSELS JR & 4375 & -111 & -123 & 4 & 62 & 8 & 4557 \\
\hline 26123210030000 & CURRENTLY UNASSIGNED & 4393 & -107 & -115 & 3 & 83 & 9 & 4571 \\
\hline 26123210100000 & VESSELS JR & 4424 & 43 & 27 & 8 & 71 & 13 & 4447 \\
\hline 26123210430000 & CURRENTLY UNASSIGNED & 4458 & 70 & 58 & 5 & 79 & 11 & 4450 \\
\hline 26123210590000 & TOLTEK DRLG CO & 4410 & -112 & -124 & 6 & 70 & 15 & 4577 \\
\hline 26123210600000 & BANDER \& COUCH & 4159 & -158 & -165 & 2 & 67 & 7 & 4407 \\
\hline 26123210740000 & BANDER \& COUCH & 4401 & 81 & 63 & 8 & 80 & 12 & 4402 \\
\hline 26123210940000 & GEAR DRILLING CO & 4471 & -64 & -69 & 4 & 70 & 5 & 4576 \\
\hline 26123211330000 & PUBCO DEVELOPMENT IN & 4420 & -48 & -56 & 2 & 71 & 7 & 4600 \\
\hline 26123211730000 & POLUMBUS CORP & 4428 & 23 & 4 & 4 & 77 & 10 & 4492 \\
\hline 26123211740000 & POLUMBUS CORP & 4429 & 75 & 65 & 4 & 80 & 8 & 4400 \\
\hline 26123211750000 & BREW & 4400 & -140 & -150 & 6 & 68 & 7 & 5279 \\
\hline 26123211840000 & SNYDER JIM & 4307 & -92 & -105 & 7 & 76 & 11 & 4477 \\
\hline 26123212650000 & TERRA RESOURCES INC & 3996 & -284 & -298 & 8 & 62 & 13 & 4397 \\
\hline
\end{tabular}




\begin{tabular}{|c|c|c|c|c|c|c|c|c|}
\hline WELL ID & OPERATOR & $\begin{array}{c}\text { KB } \\
\text { ELEV }\end{array}$ & \begin{tabular}{|l} 
TOP J \\
SUBSEA
\end{tabular} & $\begin{array}{l}\text { BASE J1 } \\
\text { SUBSEA }\end{array}$ & $\begin{array}{c}\text { J1 NET } \\
\text { THICKNESS }\end{array}$ & $\begin{array}{c}\text { INTERVAL } \\
\text { HUNTSMAN } \\
\text { SHALE } \\
\text { MARKER to } \\
\text { TOP OF J } \\
\end{array}$ & \begin{tabular}{|c} 
MAX \\
RESISTIVITY \\
WITHIN J1 \\
INTERVAL
\end{tabular} & TD \\
\hline 26123212660000 & GEAR DRILLING CO & 3979 & -318 & -331 & 3 & 61 & 11 & 4397 \\
\hline 26123212760000 & GEAR DRILLING CO & 4378 & -128 & -138 & 6 & 68 & 7 & 4599 \\
\hline 26123212870000 & SUNDANCE OIL CO & 3786 & -446 & -462 & 0 & 64 & 6 & 4325 \\
\hline 26123212890000 & SUNDANCE OIL CO & 4069 & & & & & & 4373 \\
\hline 26123212940000 & SUNDANCE OIL CO & 3810 & -496 & -513 & 4 & 60 & 7 & 4395 \\
\hline 26123212970000 & SUNDANCE OIL CO & 3845 & -438 & -453 & 5 & 64 & 8 & 4373 \\
\hline 26123213200000 & SUNDANCE OIL CO & 3808 & -472 & -492 & 2 & 49 & 9 & 4370 \\
\hline 26123213350000 & WEBB RESOURCES INC & 4055 & -249 & -262 & 8 & 59 & 7 & 4427 \\
\hline 26123213360000 & SUNDANCE OIL CO & 3810 & -469 & -483 & 1 & 57 & 6 & 4373 \\
\hline 26123213370000 & WEBB RESOURCES INC & 3968 & -282 & -297 & 6 & 62 & 10 & 4328 \\
\hline 26123213580000 & GEAR DRILLING CO & 4378 & -110 & -123 & 6 & 67 & 10 & 4595 \\
\hline 26123213600000 & ACKMAN & 4343 & -106 & -117 & 5 & 73 & 8 & 4504 \\
\hline 26123213740000 & GEAR DRILLING CO & 4424 & -118 & -129 & 3 & 66 & 10 & 4636 \\
\hline 26123213830000 & MALLON PRODUCTION CO & 4137 & -215 & -232 & 5 & 62 & 7 & 4451 \\
\hline 26123213840000 & GEAR DRILLING CO & 4382 & -107 & -118 & 4 & 73 & 15 & 4588 \\
\hline 26123213860000 & MALLON PRODUCTION CO & 4155 & -203 & -223 & 8 & 63 & 11 & 4457 \\
\hline 26123214490000 & SOHIO PETROLEUM CO & 4438 & -24 & & & & & 6955 \\
\hline 26123214800000 & MALLON PRODUCTION CO & 4395 & -107 & & & & & 6932 \\
\hline 26123215070000 & SNYDER JIM & 4058 & -182 & -191 & 3 & 64 & 8 & 4332 \\
\hline 26153053100000 & CURRENTLY UNASSIGNED & 4056 & -893 & & & 76 & & 5037 \\
\hline 26157050750000 & GARY & 4141 & -1057 & -1063 & 3 & 56 & 23 & 5275 \\
\hline 26157050770000 & DAVIS OIL CO (EDWARD & 4709 & -1343 & -1343 & 0 & 56 & & 6092 \\
\hline 26157050780000 & SHELL OIL CO & 4441 & -1337 & -1359 & 22 & 57 & 30 & 5849 \\
\hline 26157050780001 & STUARCO OIL CO INC & 4441 & & & & & & 2720 \\
\hline 26157050790000 & CANNON DALE & 4138 & -1136 & -1142 & 0 & 52 & 8 & 5375 \\
\hline 26157050800000 & CORAL PRODUCTION COR & 4353 & -1329 & -1341 & 10 & 57 & 68 & 5707 \\
\hline 26157050810000 & DAVIS & 4821 & -1407 & -1425 & 14 & 58 & 12 & 6306 \\
\hline 26157050820000 & GARY & 4091 & -1151 & -1156 & 1 & 50 & 7 & 5300 \\
\hline 26157050830000 & GARY & 4127 & -1141 & -1147 & 0 & 55 & 7 & 5333 \\
\hline 26157050840000 & GARY & 4122 & -1162 & -1166 & 0 & 54 & 12 & 5321 \\
\hline 26157050850000 & GARY & 4226 & -1214 & -1219 & 3 & 52 & 20 & 5509 \\
\hline 26157050860000 & BANNER OIL CO INC & 4229 & -1047 & -1058 & 6 & 54 & 12 & 5350 \\
\hline 26157050870000 & GARY & 4082 & -1140 & -1150 & 5 & 52 & 42 & 5293 \\
\hline 26157050880000 & VESSELS JR & 4376 & -1339 & -1350 & 2 & & 3 & 5750 \\
\hline 26157050890000 & BANNER OIL CO INC & 4272 & -1286 & -1298 & 4 & 51 & 10 & 5640 \\
\hline 26157050900000 & CURRENTLY UNASSIGNED & 4285 & -1295 & -1305 & 2 & 56 & 5 & 5650 \\
\hline 26157050910000 & BRINKERHOFF DRLG CO & 4129 & -1210 & -1223 & 13 & 53 & 22 & 5398 \\
\hline 26157050920000 & CHIEF DRLG CO & 4089 & -1159 & -1177 & 15 & 52 & 15 & 5340 \\
\hline 26157050930000 & GARY & 4063 & -1151 & -1159 & 3 & 56 & 4 & 5236 \\
\hline 26157050940000 & SUN OIL CO & 4198 & -1026 & -1044 & 15 & 58 & 13 & 5267 \\
\hline 26157050950000 & GARY & 4063 & -1073 & -1083 & 7 & 58 & 15 & 5208 \\
\hline
\end{tabular}




\begin{tabular}{|c|c|c|c|c|c|c|c|c|}
\hline WELL ID & OPERATOR & $\begin{array}{c}\text { KB } \\
\text { ELEV }\end{array}$ & \begin{tabular}{|l} 
TOP J \\
SUBSEA
\end{tabular} & $\begin{array}{l}\text { BASE J1 } \\
\text { SUBSEA }\end{array}$ & $\begin{array}{c}\text { J1 NET } \\
\text { THICKNESS }\end{array}$ & $\begin{array}{c}\text { INTERVAL } \\
\text { HUNTSMAN } \\
\text { SHALE } \\
\text { MARKER to } \\
\text { TOP OF J } \\
\end{array}$ & \begin{tabular}{|c} 
MAX \\
RESISTIVITY \\
WITHIN J1 \\
INTERVAL
\end{tabular} & TD \\
\hline 26157050960000 & EXETER DRLG \& EXPL & 3901 & -778 & -786 & 1 & 61 & 10 & 4755 \\
\hline 26157050970000 & GARY & 4051 & -1156 & & & 53 & & 5333 \\
\hline 26157050980000 & SHELL OIL CO & 4399 & -1297 & -1297 & 0 & 57 & & 5762 \\
\hline 26157050990000 & BANNER OIL CO INC & 4133 & -1251 & -1265 & 8 & 56 & 15 & 5424 \\
\hline 26157051000000 & EXETER DRLG \& EXPL & 4085 & -913 & -931 & 11 & 64 & 11 & 5080 \\
\hline 26157051010000 & BEL-AIR OIL CO & 4804 & -1468 & -1474 & 0 & 60 & 2 & 6343 \\
\hline 26157051030000 & GARY & 4400 & -1274 & -1287 & 5 & 56 & 3 & 5740 \\
\hline 26157051040000 & GARY & 4034 & -1150 & -1155 & 3 & 54 & 23 & 5239 \\
\hline 26157051060000 & MORWELL CO & 4406 & -1286 & -1299 & 5 & 56 & 25 & 5730 \\
\hline 26157051070000 & WHITE FEATHER PETROL & 4168 & -1276 & -1291 & 8 & 56 & 12 & 5495 \\
\hline 26157051080000 & GARY & 4350 & -1266 & -1277 & 5 & 54 & 7 & 5669 \\
\hline 26157051090000 & GARY & 4032 & -1136 & -1168 & 26 & 54 & 32 & 5208 \\
\hline 26157051100000 & BANNER OIL CO INC & 3799 & -668 & -684 & 13 & 73 & 12 & 4740 \\
\hline 26157051110000 & S \& B OIL CO & 4387 & -1275 & -1288 & 10 & 57 & 35 & 5718 \\
\hline 26157051120000 & CURRENTLY UNASSIGNED & 3965 & -869 & -885 & 14 & 66 & 13 & 4910 \\
\hline 26157051130000 & CURRENTLY UNASSIGNED & 3902 & -826 & -850 & 17 & 64 & 12 & 4785 \\
\hline 26157051140000 & SHELL OIL CO & 4425 & -1285 & -1293 & 1 & 58 & 5 & 5770 \\
\hline 26157051150000 & GARY & 4085 & -1221 & & & & & 5355 \\
\hline 26157051160000 & CANNON DALE & 4026 & -1119 & -1142 & 21 & 56 & 62 & 5210 \\
\hline 26157051180000 & WYOMING-WESTERN OIL & 4012 & -1086 & -1094 & 4 & 60 & 15 & 5167 \\
\hline 26157051190000 & SUN OIL CO & 4020 & -1102 & -1122 & 8 & 53 & 15 & 5180 \\
\hline 26157051200000 & SKAER & 4051 & -1131 & & & & & 5185 \\
\hline 26157051230000 & YOUNT FOUNDATION INC & 4015 & -1105 & -1121 & 7 & 57 & 33 & 5175 \\
\hline 26157051240000 & RED FEATHER PETROLEU & 4044 & -1128 & -1155 & 25 & 53 & 37 & 5240 \\
\hline 26157051250000 & AK-SAR-BEN PETROLEUM & 4020 & -1102 & -1127 & 18 & 54 & 62 & 5190 \\
\hline 26157051260000 & DAVIS OIL CO (EDWARD & 3993 & -979 & -985 & 6 & 68 & 36 & 5028 \\
\hline 26157051270000 & CURRENTLY UNASSIGNED & 3799 & -641 & -657 & 14 & & 2 & 4502 \\
\hline 26157051280000 & GARY & 3936 & -838 & -852 & 9 & 62 & 16 & 4840 \\
\hline 26157051290000 & AK-SAR-BEN PETROLEUM & 4031 & -1115 & -1141 & 22 & 54 & 60 & 5208 \\
\hline 26157051300000 & STRATA OIL CO INC & 3831 & -718 & -725 & 3 & 65 & 7 & 4645 \\
\hline 26157051310000 & GARY & 3938 & -802 & -823 & 19 & 59 & 18 & 4803 \\
\hline 26157051330000 & U S SMELTING REFININ & 3802 & -626 & -646 & 16 & & 5 & 4505 \\
\hline 26157051350000 & SUN OIL CO & 4052 & -1141 & -1172 & 28 & 54 & 17 & 5250 \\
\hline 26157051370000 & DAVIS & 4876 & -1443 & -1458 & 10 & 61 & 18 & 6370 \\
\hline 26157051380000 & YOUNT FOUNDATION INC & 4029 & -1117 & -1145 & 25 & 56 & 47 & 5210 \\
\hline 26157051390000 & SUN OIL CO & 4005 & -1087 & -1105 & 13 & 60 & 70 & 5135 \\
\hline 26157051400000 & SUN OIL CO & 4005 & -1083 & -1101 & 8 & 59 & 72 & 5170 \\
\hline 26157051410000 & YOUNT FOUNDATION INC & 4020 & -1096 & -1116 & 12 & 57 & 65 & 5161 \\
\hline 26157051420000 & ALLISON & 4001 & -864 & -873 & 6 & 69 & 14 & 5002 \\
\hline 26157051430000 & GARY & 4029 & -863 & -872 & 6 & 60 & 15 & 4960 \\
\hline 26157051440000 & VESSELS JR & 3805 & -653 & -665 & 10 & 69 & 10 & \begin{tabular}{|l|}
4505 \\
\end{tabular} \\
\hline
\end{tabular}




\begin{tabular}{|c|c|c|c|c|c|c|c|c|}
\hline WELL ID & OPERATOR & $\begin{array}{c}\text { KB } \\
\text { ELEV }\end{array}$ & \begin{tabular}{|l} 
TOP J \\
SUBSEA
\end{tabular} & $\begin{array}{l}\text { BASE J1 } \\
\text { SUBSEA }\end{array}$ & $\begin{array}{c}\text { J1 NET } \\
\text { THICKNESS }\end{array}$ & $\begin{array}{c}\text { INTERVAL } \\
\text { HUNTSMAN } \\
\text { SHALE } \\
\text { MARKER to } \\
\text { TOP OF J } \\
\end{array}$ & \begin{tabular}{|c} 
MAX \\
RESISTIVITY \\
WITHIN J1 \\
INTERVAL
\end{tabular} & TD \\
\hline 26157051450000 & STUARCO OIL CO INC & 4400 & -1336 & -1343 & 5 & 61 & 8 & 5800 \\
\hline 26157051460000 & BANNER OIL CO INC & 3860 & -773 & -794 & 6 & 65 & 16 & 4705 \\
\hline 26157051470000 & STRATA OIL CO INC & 3839 & -737 & -751 & 4 & 63 & 13 & 4675 \\
\hline 26157051480000 & STUARCO OIL CO INC & 4002 & -1075 & -1088 & 8 & 61 & 60 & 5150 \\
\hline 26157051490000 & YOUNT FOUNDATION INC & 4013 & -1083 & -1097 & 13 & 58 & 100 & 5170 \\
\hline 26157051500000 & VESSELS JR & 4015 & -919 & -929 & 7 & 62 & 18 & 4990 \\
\hline 26157051510000 & STUARCO OIL CO INC & 4002 & -1076 & -1088 & 8 & 58 & 60 & 5151 \\
\hline 26157051520000 & YOUNT FOUNDATION INC & 4024 & -1106 & -1128 & 19 & 59 & 72 & 5185 \\
\hline 26157051530000 & DAVIS OIL CO (EDWARD & 3957 & -985 & -996 & 7 & 66 & 27 & 5016 \\
\hline 26157051540000 & U S SMELTING REFININ & 3804 & -622 & -641 & 12 & & 3 & 4486 \\
\hline 26157051550000 & BRINKERHOFF DRLG CO & 3995 & -813 & -833 & 16 & 65 & 12 & 4874 \\
\hline 26157051560000 & SUN OIL CO & 4024 & -1124 & -1144 & 16 & 58 & 68 & 5200 \\
\hline 26157051570000 & CURRENTLY UNASSIGNED & 3798 & -586 & -598 & 3 & & 4 & 4475 \\
\hline 26157051580000 & SKAER & 4026 & -1140 & -1152 & 6 & 62 & 40 & 5230 \\
\hline 26157051590000 & GARY & 4020 & -1120 & -1132 & 12 & 60 & 50 & 5215 \\
\hline 26157051600000 & NEBRASKA DEVELOPMENT & 4005 & -1072 & -1084 & 7 & 58 & 60 & 5140 \\
\hline 26157051620000 & YOUNT FOUNDATION INC & 4011 & -1083 & -1099 & 12 & 62 & 69 & 5151 \\
\hline 26157051630000 & YOUNT FOUNDATION INC & 4016 & -1104 & -1118 & 12 & 59 & 48 & 5200 \\
\hline 26157051640000 & CURRENTLY UNASSIGNED & 3804 & -624 & -642 & 14 & 73 & 3 & 4500 \\
\hline 26157051650000 & GARY & 4056 & -853 & -860 & 6 & 63 & 10 & 4970 \\
\hline 26157051660000 & BANNER OIL CO INC & 3840 & -754 & -772 & 7 & 67 & 13 & 4684 \\
\hline 26157051690000 & CRAMER & 4206 & -1279 & -1286 & 2 & 57 & 19 & 5533 \\
\hline 26157051700000 & UNION TEXAS PETROLEU & 3972 & -877 & -894 & 6 & 60 & 15 & 4919 \\
\hline 26157051710000 & REGAL DRLG CO & 3836 & -766 & -766 & & & & 4684 \\
\hline 26157051720000 & REGAL DRLG CO & 3828 & -753 & -771 & 10 & 66 & 12 & 4675 \\
\hline 26157051730000 & WILLIAMSON & 3809 & -639 & -653 & 8 & 67 & 3 & 4524 \\
\hline 26157051740000 & STUARCO OIL CO INC & 4034 & -1164 & -1178 & 8 & & 15 & 5250 \\
\hline 26157051750000 & DAVIS OIL CO (EDWARD & 4322 & -1344 & -1352 & 5 & 63 & 21 & 5720 \\
\hline 26157051760000 & STUARCO OIL CO INC & 4100 & -1098 & -1106 & 0 & 62 & 8 & 5258 \\
\hline 26157051770000 & BRINKERHOFF DRLG CO & 4079 & -1217 & -1227 & 4 & 64 & 4 & 5392 \\
\hline 26157051780000 & STUARCO OIL CO INC & 4725 & -1502 & -1515 & 1 & 63 & 6 & 6301 \\
\hline 26157051800000 & CURRENTLY UNASSIGNED & 3932 & -808 & -817 & 2 & 62 & 5 & 4594 \\
\hline 26157051810000 & CURRENTLY UNASSIGNED & 4777 & -1427 & -1435 & 2 & 62 & 3 & 6280 \\
\hline 26157051820000 & GARY & 3925 & -933 & -949 & 5 & 70 & 8 & 4923 \\
\hline 26157051840000 & WHITE FEATHER PETROL & 4123 & -1177 & -1192 & 5 & 64 & 9 & 5343 \\
\hline 26157051850000 & GARY & 4127 & -1222 & -1230 & 6 & 63 & 2 & 5400 \\
\hline 26157051870000 & CURRENTLY UNASSIGNED & 3910 & -896 & -904 & 4 & 70 & 22 & 4878 \\
\hline 26157051880000 & SHELL OIL CO & 3890 & -846 & -854 & 2 & 72 & 17 & 4816 \\
\hline 26157051890000 & DAVIS OIL CO (EDWARD & 4204 & -1166 & -1181 & 10 & 64 & 13 & 5440 \\
\hline 26157051930000 & CURRENTLY UNASSIGNED & 3859 & -541 & -551 & 4 & 78 & 15 & 4505 \\
\hline 26157051940000 & MCDANIEL DRLG CO & 4251 & -1123 & -1137 & 7 & 63 & 5 & 5433 \\
\hline
\end{tabular}




\begin{tabular}{|c|c|c|c|c|c|c|c|c|}
\hline WELL ID & OPERATOR & $\begin{array}{c}\text { KB } \\
\text { ELEV }\end{array}$ & \begin{tabular}{|l} 
TOP J \\
SUBSEA
\end{tabular} & $\begin{array}{l}\text { BASE J1 } \\
\text { SUBSEA }\end{array}$ & $\begin{array}{c}\text { J1 NET } \\
\text { THICKNESS }\end{array}$ & $\begin{array}{c}\text { INTERVAL } \\
\text { HUNTSMAN } \\
\text { SHALE } \\
\text { MARKER to } \\
\text { TOP OF J } \\
\end{array}$ & \begin{tabular}{|c|} 
MAX \\
RESISTIVITY \\
WITHIN J1 \\
INTERVAL
\end{tabular} & TD \\
\hline 26157051960000 & VESSELS JR & 4236 & -1246 & -1260 & 12 & 62 & 17 & 5590 \\
\hline 26157051970000 & BANNER OIL CO INC & 3888 & -488 & -497 & 6 & 86 & 8 & 4417 \\
\hline 26157051980000 & STUARCO OIL CO INC & 3960 & -962 & -976 & 3 & 71 & 20 & 4987 \\
\hline 26157052000000 & REGAL DRLG CO & 4379 & -1292 & -1307 & 6 & 66 & 13 & 5725 \\
\hline 26157052010000 & BANNER OIL CO INC & 3829 & -529 & -541 & 8 & 72 & 14 & 4468 \\
\hline 26157052030000 & VESSELS JR & 3888 & -534 & -550 & 11 & 79 & 7 & 4508 \\
\hline 26157052040000 & CURRENTLY UNASSIGNED & 3942 & -788 & -796 & 4 & & 3 & 4843 \\
\hline 26157052050000 & VESSELS JR & 4532 & -1474 & -1488 & 6 & 66 & 19 & 6084 \\
\hline 26157052070000 & CHAIN OIL INC & 3903 & -585 & -604 & 8 & & 10 & 4567 \\
\hline 26157052080000 & TOLTEK DRLG CO & 3845 & -731 & -739 & 0 & 68 & 3 & 4680 \\
\hline 26157052090000 & WHITE FEATHER PETROL & 4475 & -1521 & -1530 & 2 & 66 & 10 & 6050 \\
\hline 26157052100000 & STRATA OIL CO INC & 3912 & -591 & -614 & 5 & 77 & 8 & 4560 \\
\hline 26157052110000 & BRINKERHOFF DRLG CO & 3844 & -656 & -666 & 6 & 63 & 6 & 4602 \\
\hline 26157052120000 & GARY & 3861 & -617 & -639 & 14 & 70 & 10 & 4575 \\
\hline 26157052130000 & PETROLEUM INC & 3844 & -538 & -554 & 7 & 76 & 11 & 4480 \\
\hline 26157052140000 & STANOLIND OIL \& GAS & 3876 & -853 & -861 & 4 & & 3 & 5000 \\
\hline 26157052150000 & DAVIS & 4236 & -1246 & -1266 & 14 & 68 & 7 & 5576 \\
\hline 26157052170000 & WYOMING-WESTERN OIL & 4328 & -1352 & -1369 & 6 & 67 & 13 & 5776 \\
\hline 26157052180000 & CHAIN & 3919 & -581 & -595 & 3 & 72 & 7 & 4600 \\
\hline 26157052190000 & BANNER OIL CO INC & 3912 & -546 & -564 & 3 & 78 & 10 & 4560 \\
\hline 26157052200000 & CURRENTLY UNASSIGNED & 4024 & -1127 & -1140 & 1 & 66 & 10 & 5201 \\
\hline 26157052210000 & DAVIS OIL CO (EDWARD & 4071 & -1173 & -1189 & 1 & 67 & 6 & 5343 \\
\hline 26157052220000 & VESSELS JR & 3857 & -703 & -709 & 2 & 64 & 11 & 4737 \\
\hline 26157052230000 & STUARCO OIL CO INC & 3930 & -552 & -576 & 20 & 72 & 15 & 4554 \\
\hline 26157052240000 & SINCLAIR OIL \& GAS C & 3934 & -539 & -562 & 14 & 73 & 21 & 4594 \\
\hline 26157052260000 & BANNER OIL CO INC & 3936 & -544 & -568 & 14 & 70 & 12 & 4580 \\
\hline 26157052270000 & SINCLAIR OIL \& GAS C & 3953 & -546 & -573 & 22 & 75 & 27 & 4570 \\
\hline 26157052280000 & BANNER OIL CO INC & 3939 & -545 & -571 & 17 & 71 & 12 & 4550 \\
\hline 26157052290000 & AK-SAR-BEN PETROLEUM & 3957 & -531 & -557 & 15 & 75 & 18 & 4580 \\
\hline 26157052310000 & SHELL OIL CO & 3971 & -1075 & -1088 & 8 & 65 & 16 & 5152 \\
\hline 26157052320000 & GARY & 3955 & -533 & -555 & 12 & 76 & 18 & 4581 \\
\hline 26157052320001 & GARY & 3955 & & & & & & 4581 \\
\hline 26157052330000 & VESSELS JR & 3960 & -550 & -575 & 19 & 76 & 11 & 4587 \\
\hline 26157052340000 & AK-SAR-BEN PETROLEUM & 3958 & -538 & -564 & 21 & 71 & 35 & 4585 \\
\hline 26157052350000 & STUARCO OIL CO INC & 3963 & -537 & -561 & 23 & 76 & 17 & 4580 \\
\hline 26157052360000 & BANNER OIL CO INC & 3991 & -407 & -412 & 3 & 83 & 5 & 4471 \\
\hline 26157052370000 & AK-SAR-BEN PETROLEUM & 3965 & -557 & -577 & 18 & 76 & 10 & 4617 \\
\hline 26157052380000 & REGAL DRLG CO & 3948 & -570 & -588 & 9 & 71 & 2 & 4678 \\
\hline 26157052390000 & AK-SAR-BEN PETROLEUM & 3961 & -525 & -553 & 24 & 73 & 48 & 4578 \\
\hline 26157052400000 & STUARCO OIL CO INC & 3957 & -533 & -549 & 2 & 79 & 5 & 4570 \\
\hline 26157052410000 & STUARCO OIL CO INC & 3960 & -550 & -572 & 18 & 74 & 18 & 4580 \\
\hline
\end{tabular}




\begin{tabular}{|c|c|c|c|c|c|c|c|c|}
\hline WELL ID & OPERATOR & $\begin{array}{c}\text { KB } \\
\text { ELEV }\end{array}$ & \begin{tabular}{|l} 
TOP J \\
SUBSEA
\end{tabular} & $\begin{array}{l}\text { BASE J1 } \\
\text { SUBSEA }\end{array}$ & $\begin{array}{c}\text { J1 NET } \\
\text { THICKNESS }\end{array}$ & $\begin{array}{c}\text { INTERVAL } \\
\text { HUNTSMAN } \\
\text { SHALE } \\
\text { MARKER to } \\
\text { TOP OF J } \\
\end{array}$ & \begin{tabular}{|c|} 
MAX \\
RESISTIVITY \\
WITHIN J1 \\
INTERVAL
\end{tabular} & TD \\
\hline 26157052420000 & AK-SAR-BEN PETROLEUM & 3962 & -538 & -562 & 15 & 75 & 44 & 4579 \\
\hline 26157052440000 & ALLISON & 3954 & -538 & -562 & 4 & 78 & 17 & 4556 \\
\hline 26157052450000 & STUARCO OIL CO INC & 3962 & -538 & & & & & 4561 \\
\hline 26157052460000 & WHITE FEATHER PETROL & 3967 & -537 & -562 & 6 & 78 & 15 & 4615 \\
\hline 26157052470000 & BANNER OIL CO INC & 3971 & -559 & -581 & 4 & 76 & 9 & 4580 \\
\hline 26157052490000 & WYOMING-WESTERN OIL & 4029 & -1240 & -1257 & 2 & 69 & 10 & 5365 \\
\hline 26157052500000 & WHITE FEATHER PETROL & 3981 & -535 & -561 & 12 & 78 & 17 & 4575 \\
\hline 26157052510000 & VANSON PRODUCTION CO & 3973 & -564 & -588 & 18 & 76 & 10 & 4610 \\
\hline 26157052520000 & EVERTSON & 3974 & -534 & -557 & 17 & & 33 & 4583 \\
\hline 26157052520001 & EVERTSON & 3974 & & & & & & 4577 \\
\hline 26157052540000 & CURRENTLY UNASSIGNED & 3931 & -1075 & -1087 & 10 & 68 & 13 & 5085 \\
\hline 26157052550000 & BANNER OIL CO INC & 3989 & -536 & -558 & 11 & & 5 & 4544 \\
\hline 26157052560000 & CURRENTLY UNASSIGNED & 3994 & -576 & -594 & 10 & 70 & 12 & 4850 \\
\hline 26157052570000 & C \& M OIL INC & 3987 & -523 & -545 & 18 & 76 & 17 & 4570 \\
\hline 26157052580000 & WHITE FEATHER PETROL & 3973 & -523 & -546 & 15 & 75 & 27 & 4640 \\
\hline 26157052600000 & MURFIN DRLG CO INC & 3973 & -518 & -535 & 3 & 76 & 5 & 4557 \\
\hline 26157052610000 & GARY & 4100 & -1418 & -1434 & 4 & 68 & 12 & 5620 \\
\hline 26157052620000 & SHELL OIL CO & 3903 & -929 & -934 & 0 & 67 & 5 & 4928 \\
\hline 26157052630000 & SUN OIL CO & 3986 & -528 & -546 & 8 & 79 & 11 & 4580 \\
\hline 26157052650000 & SUN OIL CO & 3986 & -556 & -573 & 7 & 73 & 13 & 4642 \\
\hline 26157052660000 & BANNER OIL CO INC & 3993 & -537 & -560 & 17 & 82 & 23 & 4575 \\
\hline 26157052670000 & ALLISON BROS DRLG CO & 3997 & -518 & -531 & 2 & 77 & 7 & 4588 \\
\hline 26157052680000 & ALLISON & 4003 & -524 & -537 & 3 & 76 & 11 & 4568 \\
\hline 26157052690000 & CURRENTLY UNASSIGNED & 4003 & -551 & -561 & 1 & 70 & 4 & 4805 \\
\hline 26157052700000 & BANNER OIL CO INC & 3992 & -516 & -538 & 10 & 80 & 11 & 4565 \\
\hline 26157052710000 & BANNER OIL CO INC & 4007 & -529 & -549 & 4 & 80 & 18 & 4593 \\
\hline 26157052720000 & BANNER OIL CO INC & 4056 & -507 & -528 & 1 & 83 & 8 & 4614 \\
\hline 26157052740000 & ALLISON & 4030 & -518 & -530 & 0 & 78 & 5 & 4626 \\
\hline 26157052750000 & SUN OIL CO & 4011 & -575 & -587 & 2 & 79 & 5 & 4704 \\
\hline 26157052760000 & ANSCHUTZ DRLG CO INC & 4061 & -554 & -576 & 22 & 77 & 7 & 4814 \\
\hline 26157052780000 & CURRENTLY UNASSIGNED & 4065 & -549 & -565 & 6 & 78 & 5 & 4735 \\
\hline 26157052790000 & BANNER OIL CO INC & 4077 & -505 & -523 & 6 & 74 & 10 & 4644 \\
\hline 26157052800000 & CURRENTLY UNASSIGNED & 3975 & -795 & -803 & 3 & 72 & 13 & 4841 \\
\hline 26157052810000 & SHELL OIL CO & 3950 & -1130 & -1139 & 8 & 70 & 15 & 5248 \\
\hline 26157052820000 & STUARCO OIL CO INC & 4077 & -579 & -589 & 0 & 82 & 5 & 4750 \\
\hline 26157052830000 & GARY & 3970 & -868 & -874 & 2 & 66 & 7 & 4939 \\
\hline 26157052840000 & TOLTEK DRLG CO & 4138 & -406 & -415 & 3 & 96 & 9 & 4640 \\
\hline 26157052860000 & WYOMING-WESTERN OIL & 3985 & -1258 & -1268 & 5 & 73 & 7 & 5325 \\
\hline 26157052900000 & ROYSTER & 4014 & -697 & -706 & 3 & 73 & 7 & 4865 \\
\hline 26157052920000 & SHELL OIL CO & 4003 & -962 & -965 & 0 & 65 & 5 & 5088 \\
\hline 26157052930000 & BRINKERHOFF DRLG CO & 4035 & -596 & -601 & 1 & & 2 & 4725 \\
\hline
\end{tabular}




\begin{tabular}{|c|c|c|c|c|c|c|c|c|}
\hline WELL ID & OPERATOR & $\begin{array}{c}\text { KB } \\
\text { ELEV }\end{array}$ & \begin{tabular}{|l} 
TOP J \\
SUBSEA
\end{tabular} & $\begin{array}{l}\text { BASE J1 } \\
\text { SUBSEA }\end{array}$ & $\begin{array}{c}\text { J1 NET } \\
\text { THICKNESS }\end{array}$ & $\begin{array}{c}\text { INTERVAL } \\
\text { HUNTSMAN } \\
\text { SHALE } \\
\text { MARKER to } \\
\text { TOP OF J } \\
\end{array}$ & \begin{tabular}{|c} 
MAX \\
RESISTIVITY \\
WITHIN J1 \\
INTERVAL
\end{tabular} & TD \\
\hline 26157052940000 & WYOMING-WESTERN OIL & 4045 & -797 & -809 & 0 & 77 & 8 & 4978 \\
\hline 26157052950000 & CHANDLER \& ASSOC INC & 4019 & -847 & -863 & 0 & 73 & 4 & 4970 \\
\hline 26157052960000 & REGAL DRLG CO & 3936 & -1046 & -1063 & 12 & 72 & 11 & 5065 \\
\hline 26157052970000 & SHELL OIL CO & 3997 & -875 & -879 & 2 & 66 & 5 & 5000 \\
\hline 26157052980000 & CURRENTLY UNASSIGNED & 4023 & -857 & -861 & 2 & 72 & 5 & 4991 \\
\hline 26157052990000 & BANNER OIL CO INC & 4059 & -621 & -626 & 0 & 83 & 4 & 4780 \\
\hline 26157053000000 & ROUNDS CO & 4370 & -93 & -101 & 6 & & & 4530 \\
\hline 26157053010000 & TOLTEK DRLG CO & 4068 & -842 & -842 & 0 & 75 & & 4978 \\
\hline 26157053020000 & HLM DRLG CO & 4042 & -887 & -890 & 0 & 135 & 3 & 5004 \\
\hline 26157053030000 & SHELL OIL CO & 4059 & -643 & -650 & 2 & 80 & 12 & 4851 \\
\hline 26157053050000 & CURRENTLY UNASSIGNED & 4161 & -545 & -557 & 0 & 89 & 5 & 4789 \\
\hline 26157053060000 & DAVIS OIL CO (EDWARD & 4219 & -705 & -717 & 3 & & 10 & 5087 \\
\hline 26157053080000 & SHELL OIL CO & 4010 & -954 & -957 & 0 & 69 & 5 & 5084 \\
\hline 26157053090000 & WYOMING-WESTERN OIL & 3958 & -1246 & -1260 & 10 & 73 & 10 & 5306 \\
\hline 26157053110000 & SHELL OIL CO & 4243 & -777 & -781 & 3 & 73 & 10 & 5140 \\
\hline 26157053120000 & DAVIS OIL CO (EDWARD & 4107 & -725 & -728 & 2 & 77 & 3 & 4946 \\
\hline 26157053130000 & STRATA OIL CO INC & 4125 & -689 & -705 & 8 & 77 & 11 & 4920 \\
\hline 26157053140000 & GARY & 4079 & -893 & -907 & 4 & 70 & 3 & 5080 \\
\hline 26157053150000 & DEKALB ENERGY CO & 4396 & -128 & -140 & 3 & & 6 & 4960 \\
\hline 26157053160000 & WILLIAMSON & 4414 & -251 & -260 & 8 & & 11 & 4800 \\
\hline 26157053180000 & CURRENTLY UNASSIGNED & 4140 & -624 & -631 & 1 & 76 & 7 & 4873 \\
\hline 26157053190000 & WYOMING-WESTERN OIL & 4074 & -1060 & -1066 & 4 & & 7 & 5198 \\
\hline 26157053200000 & CURRENTLY UNASSIGNED & 4156 & -780 & -791 & 5 & 75 & 12 & 5057 \\
\hline 26157053220000 & SHELL OIL CO & 4085 & -1285 & -1303 & 12 & 82 & 17 & 5488 \\
\hline 26157053230000 & DEKALB ENERGY CO & 4378 & -154 & -161 & 5 & & 12 & 4937 \\
\hline 26157053240000 & CURRENTLY UNASSIGNED & 4153 & -859 & -867 & 4 & & 12 & 5087 \\
\hline 26157053250000 & SHELL OIL CO & 4321 & -383 & -395 & 10 & 104 & 10 & 4803 \\
\hline 26157053260000 & DAVIS OIL CO (EDWARD & 4063 & -1054 & -1066 & 11 & & 10 & 5227 \\
\hline 26157053800000 & STUARCO OIL CO INC & 3917 & -802 & -825 & 16 & 62 & 15 & 4780 \\
\hline 26157053810000 & GEAR DRILLING CO & 3835 & -740 & & & & & 4650 \\
\hline 26157053820000 & STRATA OIL CO INC & 3965 & -957 & -970 & 10 & 66 & 15 & 4982 \\
\hline 26157053830000 & REGAL DRLG CO & 4263 & -1301 & -1324 & 14 & 59 & 17 & 5640 \\
\hline 26157053840000 & BANNER OIL CO INC & 3978 & -518 & -542 & 16 & 78 & 35 & 4570 \\
\hline 26157053850000 & STUARCO OIL CO INC & 4105 & -859 & -864 & 0 & 73 & 3 & 5096 \\
\hline 26157053900000 & STUARCO OIL CO INC & 4426 & -1336 & -1361 & 23 & 57 & 18 & 5810 \\
\hline 26157053910000 & BANNER OIL CO INC & 4038 & -472 & -472 & 0 & 89 & & 4587 \\
\hline 26157053920000 & REGAL DRLG CO & 3814 & -610 & -622 & 8 & & 8 & 4527 \\
\hline 26157053930000 & WHITE FEATHER PETROL & 4004 & -1070 & -1078 & 3 & & 64 & 5192 \\
\hline 26157053940000 & WHITE FEATHER PETROL & 3997 & -1060 & & & & & 5108 \\
\hline 26157053950000 & BANNER DRLG CORP & 4116 & -367 & -372 & 1 & & 7 & 4800 \\
\hline 26157053960000 & WHITE FEATHER PETROL & 3995 & -531 & -543 & 3 & 80 & 8 & \begin{tabular}{|l|l|}
4588 \\
\end{tabular} \\
\hline
\end{tabular}




\begin{tabular}{|c|c|c|c|c|c|c|c|c|}
\hline WELL ID & OPERATOR & $\begin{array}{c}\text { KB } \\
\text { ELEV }\end{array}$ & \begin{tabular}{|l} 
TOP J \\
SUBSEA
\end{tabular} & $\begin{array}{l}\text { BASE J1 } \\
\text { SUBSEA }\end{array}$ & $\begin{array}{c}\text { J1 NET } \\
\text { THICKNESS }\end{array}$ & $\begin{array}{c}\text { INTERVAL } \\
\text { HUNTSMAN } \\
\text { SHALE } \\
\text { MARKER to } \\
\text { TOP OF J } \\
\end{array}$ & \begin{tabular}{|c|} 
MAX \\
RESISTIVITY \\
WITHIN J1 \\
INTERVAL
\end{tabular} & TD \\
\hline 26157053970000 & BANNER DRLG CORP & 3946 & -513 & -522 & 2 & & 6 & 4788 \\
\hline 26157053980000 & CURRENTLY UNASSIGNED & 4113 & -632 & -639 & 2 & 80 & 3 & 4810 \\
\hline 26157053990000 & STUARCO OIL CO INC & 4144 & -809 & -819 & 5 & & 9 & 5005 \\
\hline 26157054000000 & STRATA OIL CO INC & 3988 & -988 & -996 & 6 & 64 & 18 & 5031 \\
\hline 26157054010000 & REGAL DRLG CO & 4293 & -1219 & -1235 & 5 & 65 & 14 & 5591 \\
\hline 26157054020000 & REGAL DRLG CO & 4502 & -1508 & -1528 & 10 & 62 & 13 & 6100 \\
\hline 26157054060000 & GARY & 4042 & -1023 & -1028 & 0 & 67 & 3 & 5120 \\
\hline 26157054090000 & SHELL OIL CO & 4265 & -1297 & -1309 & 7 & 66 & 20 & 5640 \\
\hline 26157054090001 & SHELL OIL CO & 4265 & & & & & & 5640 \\
\hline 26157082850000 & BANNER OIL CO INC & 4052 & -424 & -436 & 5 & 88 & 13 & 4625 \\
\hline 26157190010000 & CURRENTLY UNASSIGNED & 3895 & -799 & -807 & 5 & & 3 & 4704 \\
\hline 26157190020000 & CURRENTLY UNASSIGNED & 3910 & & & & & & \\
\hline 26157190050000 & CURRENTLY UNASSIGNED & 3875 & & & & & & 253 \\
\hline 26157190060000 & CURRENTLY UNASSIGNED & 3880 & & & & & & 834 \\
\hline 26157190070000 & CURRENTLY UNASSIGNED & 4495 & & & & & & 4660 \\
\hline 26157210010000 & REGAL DRLG CO & 4054 & -1195 & -1210 & 11 & 78 & 10 & 5328 \\
\hline 26157210020000 & REGAL DRLG CO & 4134 & -980 & -986 & 5 & & 7 & 5194 \\
\hline 26157210040000 & CURRENTLY UNASSIGNED & 4495 & -85 & -93 & 3 & 73 & 13 & 4662 \\
\hline 26157210060000 & CURRENTLY UNASSIGNED & 3894 & -870 & -884 & 6 & 70 & 15 & 4840 \\
\hline 26157210080000 & CURRENTLY UNASSIGNED & 3901 & -551 & -565 & 10 & 75 & 12 & 4542 \\
\hline 26157210090000 & STUARCO OIL CO INC & 3891 & -831 & -839 & 2 & 62 & 11 & 4769 \\
\hline 26157210100000 & AK-SAR-BEN PETROLEUM & 3978 & -860 & -866 & 3 & 72 & 8 & 4915 \\
\hline 26157210110000 & AK-SAR-BEN PETROLEUM & 3953 & -551 & -569 & 3 & 76 & 5 & 4578 \\
\hline 26157210120000 & BANNER DRLG CORP & 4278 & -1280 & -1286 & 1 & 58 & 8 & 5620 \\
\hline 26157210130000 & KING RESOURCES CO & 4141 & -1225 & -1241 & 4 & 66 & 15 & 5517 \\
\hline 26157210200000 & YOUNT FOUNDATION INC & 4012 & -1096 & -1105 & 7 & 58 & 50 & 5123 \\
\hline 26157210220000 & TRIANGLE J OIL CO & 4290 & -1294 & -1304 & 2 & 58 & 9 & 5628 \\
\hline 26157210230000 & KING RESOURCES CO & 3874 & -768 & -784 & 8 & 62 & 13 & 4775 \\
\hline 26157210240000 & MONTANA PETROLEUM CO & 4077 & -994 & -1001 & 3 & 59 & 20 & 5134 \\
\hline 26157210250000 & KING RESOURCES CO & 4007 & -1059 & -1064 & 1 & 60 & 6 & 5195 \\
\hline 26157210260000 & STUARCO OIL CO INC & 4097 & -651 & -660 & 4 & 88 & 8 & 4817 \\
\hline 26157210270000 & KING RESOURCES CO & 4354 & -1323 & -1332 & 6 & 61 & 15 & 5780 \\
\hline 26157210310000 & TRIANGLE J OIL CO & 3884 & -868 & -878 & 2 & 72 & 6 & 4825 \\
\hline 26157210320000 & SKAER & 3955 & -545 & -572 & 21 & 74 & 27 & 4575 \\
\hline 26157210330000 & SUN OIL CO & 4007 & & & & & & 5088 \\
\hline 26157210340000 & CHAIN & 3954 & -544 & -564 & 12 & 70 & 10 & 4576 \\
\hline 26157210350000 & SMETHERS & 3950 & -536 & -554 & 4 & 76 & 6 & 4562 \\
\hline 26157210360000 & BOEKEL & 3957 & -551 & -579 & 22 & 74 & 17 & 4578 \\
\hline 26157210370000 & B W DRLG INC & 3883 & -809 & -830 & 2 & 62 & 9 & 4760 \\
\hline 26157210400000 & CURRENTLY UNASSIGNED & 3941 & -658 & -672 & 3 & 70 & 13 & 4706 \\
\hline 26157210410000 & AK-SAR-BEN PETROLEUM & 3960 & -536 & & & & & 4570 \\
\hline
\end{tabular}




\begin{tabular}{|c|c|c|c|c|c|c|c|c|}
\hline WELL ID & OPERATOR & $\begin{array}{c}\text { KB } \\
\text { ELEV }\end{array}$ & \begin{tabular}{|l} 
TOP J \\
SUBSEA
\end{tabular} & $\begin{array}{l}\text { BASE J1 } \\
\text { SUBSEA }\end{array}$ & $\begin{array}{c}\text { J1 NET } \\
\text { THICKNESS }\end{array}$ & $\begin{array}{c}\text { INTERVAL } \\
\text { HUNTSMAN } \\
\text { SHALE } \\
\text { MARKER to } \\
\text { TOP OF J } \\
\end{array}$ & \begin{tabular}{|c|} 
MAX \\
RESISTIVITY \\
WITHIN J1 \\
INTERVAL
\end{tabular} & TD \\
\hline 26157210430000 & WEBB RESOURCES INC & 4021 & -1119 & -1133 & 11 & 59 & 33 & 5200 \\
\hline 26157210450000 & STUARCO OIL CO INC & 3835 & -711 & -721 & 6 & 72 & 15 & 4627 \\
\hline 26157210500000 & SMETHERS & 3951 & -552 & -570 & 2 & 80 & 6 & 4548 \\
\hline 26157210510000 & B W DRLG INC & 4758 & -1316 & -1326 & 3 & 58 & 15 & 6100 \\
\hline 26157210520000 & CURRENTLY UNASSIGNED & 3898 & -396 & -406 & 0 & 62 & 7 & 4365 \\
\hline 26157210530000 & STUARCO OIL CO INC & 3930 & -351 & -362 & 7 & 59 & 16 & 4359 \\
\hline 26157210540000 & CHEMCO INC & 3876 & -595 & -618 & 14 & 69 & 24 & 4575 \\
\hline 26157210550000 & STUARCO OIL CO INC & 3897 & -505 & -529 & 13 & 81 & 14 & 4509 \\
\hline 26157210560000 & STUARCO OIL CO INC & 3907 & -535 & -549 & 9 & 78 & 14 & 4530 \\
\hline 26157210570000 & CURRENTLY UNASSIGNED & 3902 & & & & & & 4550 \\
\hline 26157210580000 & STUARCO OIL CO INC & 3915 & -579 & -597 & 4 & 74 & 10 & 4591 \\
\hline 26157210610000 & CAYMAN CORP & 3852 & -612 & -634 & 18 & 70 & 14 & 4534 \\
\hline 26157210620000 & BOEKEL & 3955 & -546 & -568 & 4 & 74 & 16 & 4552 \\
\hline 26157210630000 & CAYMAN CORP & 3912 & -596 & -623 & 9 & 80 & 10 & 4549 \\
\hline 26157210640000 & CAYMAN CORP & 3908 & -601 & -618 & 6 & 70 & 15 & 4570 \\
\hline 26157210650000 & BOEKEL & 3920 & -590 & -612 & 5 & 75 & 13 & 4567 \\
\hline 26157210660000 & BRADEN-GEAR DRLG CO & 3959 & & & & & & 4561 \\
\hline 26157210660001 & AK-SAR-BEN PETROLEUM & 3961 & -527 & -551 & 17 & 76 & 27 & 4555 \\
\hline 26157210670000 & BRADEN-GEAR DRLG CO & 3996 & -599 & -612 & 4 & 73 & 14 & 4670 \\
\hline 26157210690000 & AK-SAR-BEN PETROLEUM & 3950 & -528 & -546 & & 76 & 8 & 4588 \\
\hline 26157210700000 & BREW & 3974 & -570 & -589 & 12 & 72 & 10 & 4592 \\
\hline 26157210730000 & ELDER OIL CO & 3960 & -532 & -560 & 14 & 74 & 35 & 4603 \\
\hline 26157210750000 & ELDER OIL CO & 3826 & -603 & -633 & 4 & 73 & 13 & 4465 \\
\hline 26157210760000 & CURRENTLY UNASSIGNED & 3831 & -645 & -665 & 4 & 68 & 19 & 4500 \\
\hline 26157210770000 & ELDER OIL CO & 3948 & -546 & -574 & 6 & 78 & 12 & 4570 \\
\hline 26157210800000 & CURRENTLY UNASSIGNED & 3857 & -762 & -768 & 2 & 64 & 5 & 4671 \\
\hline 26157210810000 & BANDER \& COUCH & 4197 & -1270 & & & 59 & & 5526 \\
\hline 26157210820000 & CURRENTLY UNASSIGNED & 4151 & -1153 & -1168 & 4 & 67 & 10 & 5363 \\
\hline 26157210830000 & CURRENTLY UNASSIGNED & 4094 & -506 & -506 & 0 & 76 & & 4686 \\
\hline 26157210840000 & AK-SAR-BEN PETROLEUM & 3954 & -536 & -554 & 6 & 74 & 13 & 4576 \\
\hline 26157210860000 & CURRENTLY UNASSIGNED & 3909 & -581 & -600 & 4 & 76 & 11 & 4600 \\
\hline 26157210870000 & ELDER OIL CO & 3865 & -641 & -659 & 14 & 68 & 9 & 4575 \\
\hline 26157210880000 & ELDER OIL CO & 3885 & -487 & -495 & 6 & 82 & 8 & 4472 \\
\hline 26157210890000 & ELDER OIL CO & 3894 & -461 & -473 & 4 & 76 & 5 & 4480 \\
\hline 26157210900000 & STUARCO OIL CO INC & 3816 & -694 & -702 & 6 & 65 & 7 & 4581 \\
\hline 26157210910000 & CURRENTLY UNASSIGNED & 3843 & -743 & -752 & 7 & 67 & 13 & 4650 \\
\hline 26157210920000 & GEAR DRILLING CO & 4073 & -466 & -481 & 8 & 93 & 8 & 4601 \\
\hline 26157210930000 & EXETER DRLG \& EXPL & 4171 & -1229 & -1236 & 3 & 66 & 16 & 5473 \\
\hline 26157210940000 & EXETER DRLG \& EXPL & 4043 & -1217 & -1230 & 2 & 68 & 7 & 5350 \\
\hline 26157210950000 & SKAER & 4157 & -1254 & -1273 & 16 & 61 & 18 & 5463 \\
\hline 26157210960000 & VANSON PRODUCTION CO & 4872 & -1497 & -1503 & 0 & 61 & 5 & 6421 \\
\hline
\end{tabular}




\begin{tabular}{|c|c|c|c|c|c|c|c|c|}
\hline WELL ID & OPERATOR & $\begin{array}{c}\text { KB } \\
\text { ELEV }\end{array}$ & \begin{tabular}{|l} 
TOP J \\
SUBSEA
\end{tabular} & $\begin{array}{l}\text { BASE J1 } \\
\text { SUBSEA }\end{array}$ & $\begin{array}{c}\text { J1 NET } \\
\text { THICKNESS }\end{array}$ & $\begin{array}{c}\text { INTERVAL } \\
\text { HUNTSMAN } \\
\text { SHALE } \\
\text { MARKER to } \\
\text { TOP OF J } \\
\end{array}$ & \begin{tabular}{|c} 
MAX \\
RESISTIVITY \\
WITHIN J1 \\
INTERVAL
\end{tabular} & TD \\
\hline 26157210970000 & SKAER & 4147 & -1249 & -1257 & 5 & 64 & 32 & 5423 \\
\hline 26157210980000 & BANDER \& COUCH & 4159 & -1265 & -1288 & 14 & 62 & 13 & 5450 \\
\hline 26157211000000 & GEAR DRILLING CO & 4126 & -311 & -322 & 2 & & 10 & 4531 \\
\hline 26157211020000 & BANNER DRLG CORP & 3895 & & & & & & 4809 \\
\hline 26157211030000 & GEAR DRILLING CO & 4024 & -1127 & -1150 & 6 & 51 & 13 & 5214 \\
\hline 26157211040000 & MOUNTAIN PETROLEUM C & 4050 & -330 & -338 & 0 & 103 & 8 & 4492 \\
\hline 26157211050000 & PETRO-LEWIS CORP & 4174 & -1186 & -1200 & 4 & 62 & 9 & 5463 \\
\hline 26157211080000 & BANNER DRLG CORP & 4046 & -481 & -494 & 6 & 94 & 10 & 4619 \\
\hline 26157211090000 & CHAIN OIL INC & 4171 & -1262 & -1271 & 6 & 60 & 11 & 5472 \\
\hline 26157211110000 & EXETER DRLG \& EXPL & 3988 & -852 & -862 & 1 & 75 & 4 & 4901 \\
\hline 26157211120000 & GEAR DRILLING CO & 4008 & -1082 & -1097 & 10 & 60 & 60 & 5050 \\
\hline 26157211130000 & BANNER DRLG CORP & 4144 & -1249 & -1256 & 1 & 63 & 17 & 5431 \\
\hline 26157211150000 & EXETER DRLG \& EXPL & 4154 & -1236 & -1246 & 6 & 62 & 8 & 5432 \\
\hline 26157211160000 & SAGE OIL CO INC & 3926 & -894 & -903 & 0 & & 7 & 4892 \\
\hline 26157211170000 & BANNER DRLG CORP & 4160 & -1269 & & & 65 & & 5470 \\
\hline 26157211180000 & BANNER DRLG CORP & 4056 & -266 & -270 & 1 & & 3 & 4451 \\
\hline 26157211190000 & BREW & 3882 & -590 & -614 & 6 & 71 & 9 & 4527 \\
\hline 26157211220000 & B W DRLG INC & 3985 & -612 & -617 & 0 & 73 & 5 & 4709 \\
\hline 26157211230000 & BREW & 4074 & -1148 & -1155 & 3 & 55 & 8 & 5280 \\
\hline 26157211250000 & DEVON CORP & 4177 & -1499 & -1499 & 0 & 73 & & 5699 \\
\hline 26157211260000 & CENTRAL OPERATING IN & 4154 & -1242 & -1252 & 6 & 60 & 14 & 5448 \\
\hline 26157211290000 & BANDER & 4374 & -1298 & -1306 & 3 & 58 & 12 & 5724 \\
\hline 26157211300000 & CURRENTLY UNASSIGNED & 4100 & -483 & -500 & 9 & 87 & 9 & 4670 \\
\hline 26157211320000 & DEVON CORP & 4083 & -316 & -327 & 0 & & 7 & 4557 \\
\hline 26157211330000 & S \& B OIL CO & 4316 & -1274 & -1284 & 6 & 56 & 21 & 5680 \\
\hline 26157211350000 & Z \& S CONSTRUCTION I & 3950 & -551 & -566 & 4 & 74 & 8 & 4555 \\
\hline 26157211370000 & SKAER & 4167 & -1258 & -1268 & 6 & 62 & 12 & 5480 \\
\hline 26157211380000 & DEVON CORP & 4152 & -1098 & -1109 & 4 & 65 & 13 & 5295 \\
\hline 26157211390000 & VANSON PRODUCTION CO & 4852 & -1438 & -1452 & 8 & 60 & 6 & 6338 \\
\hline 26157211400000 & BREW & 4162 & -1248 & -1255 & 3 & 60 & 15 & 5450 \\
\hline 26157211410000 & BREW & 4247 & -1349 & -1358 & 2 & 60 & 11 & 5645 \\
\hline 26157211420000 & KIMBARK OIL \& GAS CO & 3894 & -546 & -555 & 6 & 78 & 8 & 4508 \\
\hline 26157211430000 & AK-SAR-BEN PETROLEUM & 3967 & -533 & -559 & 10 & 76 & 15 & 4556 \\
\hline 26157211440000 & WECO DEVELOPMENT COR & 3803 & -606 & -620 & 8 & 76 & 10 & 4480 \\
\hline 26157211450000 & B W DRLG INC & 3970 & -546 & -560 & 0 & 84 & 5 & 4558 \\
\hline 26157211470000 & Z \& S CONSTRUCTION I & 4031 & -327 & -327 & 0 & 100 & & 4436 \\
\hline 26157211480000 & MALLON PRODUCTION CO & 4427 & -147 & -155 & 4 & 86 & 7 & 4671 \\
\hline 26157211490000 & BEREN CORP & 4005 & -565 & -576 & 2 & 77 & 13 & 4650 \\
\hline 26157211500000 & SUNDANCE OIL CO & 4019 & -873 & -893 & 16 & 66 & 12 & 4927 \\
\hline 26157211520000 & BANNER DRLG CORP & 3842 & -762 & -775 & 1 & 66 & 15 & 4712 \\
\hline 26157211530000 & BANNER DRLG CORP & 4395 & -161 & -171 & 4 & & 9 & 4942 \\
\hline
\end{tabular}




\begin{tabular}{|c|c|c|c|c|c|c|c|c|}
\hline WELL ID & OPERATOR & $\begin{array}{c}\text { KB } \\
\text { ELEV }\end{array}$ & \begin{tabular}{|l} 
TOP J \\
SUBSEA
\end{tabular} & $\begin{array}{l}\text { BASE J1 } \\
\text { SUBSEA }\end{array}$ & $\begin{array}{c}\text { J1 NET } \\
\text { THICKNESS }\end{array}$ & $\begin{array}{c}\text { INTERVAL } \\
\text { HUNTSMAN } \\
\text { SHALE } \\
\text { MARKER to } \\
\text { TOP OF J } \\
\end{array}$ & \begin{tabular}{|c|} 
MAX \\
RESISTIVITY \\
WITHIN J1 \\
INTERVAL
\end{tabular} & TD \\
\hline 26157211540000 & Z \& S CONSTRUCTION I & 4040 & -367 & -375 & 4 & & 7 & 4517 \\
\hline 26157211550000 & EXETER DRLG \& EXPL & 3818 & -614 & -624 & 2 & & 3 & 4495 \\
\hline 26157211590000 & DIETRICH EXPL CO INC & 3991 & -991 & -999 & 3 & 61 & 10 & 5055 \\
\hline 26157211610000 & GIBSON WELL SERVICE & 4231 & -1285 & -1297 & 4 & 60 & 11 & 5559 \\
\hline 26157211630000 & ALCOIL EXPL INC & 4191 & -1025 & -1032 & 4 & 52 & 16 & 5300 \\
\hline 26157211640000 & SUNDANCE OIL CO & 3931 & -828 & -845 & 5 & 65 & 9 & 4802 \\
\hline 26157211650000 & TERMO CO & 3880 & -614 & & & 70 & & 4565 \\
\hline 26157211670000 & KNIGGE-SOPER OPERATI & 4164 & -208 & -230 & 14 & & & 4529 \\
\hline 26157211680000 & KNIGGE-SOPER OPERATI & 4183 & -211 & -233 & 9 & 61 & 13 & 4503 \\
\hline 26157211690000 & EXETER DRLG \& EXPL & 4241 & -211 & -237 & 22 & & 12 & 4560 \\
\hline 26157211700000 & SUNDANCE OIL CO & 3783 & -553 & -568 & 6 & 54 & 12 & 4410 \\
\hline 26157211710000 & MALLON PRODUCTION CO & 4193 & -197 & -213 & 5 & 64 & 12 & 4490 \\
\hline 26157211720000 & KNIGGE-SOPER OPERATI & 4177 & -209 & -223 & 6 & 70 & 23 & 4501 \\
\hline 26157211740000 & SUNDANCE OIL CO & 3762 & -556 & -570 & 2 & 60 & 5 & 4396 \\
\hline 26157211750000 & KNIGGE-SOPER OPERATI & 4121 & -201 & -219 & 10 & 60 & 18 & 4434 \\
\hline 26157211760000 & MALLON PRODUCTION CO & 4166 & -224 & -244 & 8 & 72 & 9 & 4490 \\
\hline 26157211770000 & SUNDANCE OIL CO & 3841 & -521 & -534 & 2 & 70 & 10 & 4446 \\
\hline 26157211780000 & DUNCAN & 3881 & -555 & -561 & 2 & 76 & 5 & 4502 \\
\hline 26157211790000 & SOPER PRODUCTION & 4000 & -552 & -566 & 1 & 74 & 7 & 4680 \\
\hline 26157211800000 & EXETER DRLG \& EXPL & 3851 & -599 & -623 & 8 & 70 & 9 & 4500 \\
\hline 26157211810000 & SUNDANCE OIL CO & 3891 & -803 & -816 & 2 & 60 & 8 & 4778 \\
\hline 26157211820000 & MALLON PRODUCTION CO & 3822 & -545 & -555 & 6 & 72 & 8 & 4439 \\
\hline 26157211830000 & BANNER DRLG CORP & 3902 & -754 & -770 & 10 & & 12 & 4762 \\
\hline 26157211850000 & MALLON PRODUCTION CO & 4119 & -223 & -231 & 5 & & 10 & 4432 \\
\hline 26157211870000 & MALLON PRODUCTION CO & 4190 & -200 & -216 & 9 & 60 & 8 & 4475 \\
\hline 26157211880000 & MALLON PRODUCTION CO & 4099 & -221 & -235 & 7 & & 8 & 4411 \\
\hline 26157211890000 & KNIGGE-SOPER OPERATI & 4146 & -214 & -234 & 13 & & 15 & 4462 \\
\hline 26157211900000 & ALCOIL EXPL INC & 4734 & -1283 & -1296 & 6 & & 20 & 6070 \\
\hline 26157211910000 & EXETER DRLG \& EXPL & 4396 & -1306 & -1312 & 2 & 58 & 3 & 5750 \\
\hline 26157211930000 & GEAR DRILLING CO & 3824 & -734 & -746 & 6 & 64 & 10 & 4636 \\
\hline 26157211940000 & GEAR DRILLING CO & 3861 & -748 & -753 & 0 & 64 & 3 & 4700 \\
\hline 26157211960000 & GEAR DRILLING CO & 3857 & -729 & -740 & 5 & 64 & 11 & 4678 \\
\hline 26157211980000 & EXAL INC & 3941 & -551 & -569 & 5 & 70 & 10 & 4556 \\
\hline 26157211990000 & EXAL INC & 3930 & -550 & -570 & 14 & & 12 & 4559 \\
\hline 26157212010000 & MILLER-CHRISTENSEN & 4114 & -502 & -513 & 4 & 86 & 8 & 4685 \\
\hline 26157212020000 & CLAYTON CORP & 4104 & -1138 & -1146 & 3 & 46 & 6 & 5330 \\
\hline 26157212030000 & MALLON PRODUCTION CO & 4170 & -208 & -218 & 4 & & 9 & 4460 \\
\hline 26157212040000 & MALLON PRODUCTION CO & 4219 & -212 & -229 & 12 & 73 & 10 & 4500 \\
\hline 26157212050000 & MALLON PRODUCTION CO & 4161 & -211 & -235 & 9 & & 11 & 4475 \\
\hline 26157212090000 & MALLON PRODUCTION CO & 4233 & -199 & -217 & 13 & 87 & 10 & 4504 \\
\hline 26157212110000 & EXAL INC & 3941 & -553 & -577 & 7 & 74 & 17 & 4557 \\
\hline
\end{tabular}




\begin{tabular}{|c|c|c|c|c|c|c|c|c|}
\hline WELL ID & OPERATOR & $\begin{array}{c}\text { KB } \\
\text { ELEV }\end{array}$ & \begin{tabular}{|l} 
TOP J \\
SUBSEA
\end{tabular} & $\begin{array}{l}\text { BASE J1 } \\
\text { SUBSEA }\end{array}$ & $\begin{array}{c}\text { J1 NET } \\
\text { THICKNESS }\end{array}$ & $\begin{array}{c}\text { INTERVAL } \\
\text { HUNTSMAN } \\
\text { SHALE } \\
\text { MARKER to } \\
\text { TOP OF J } \\
\end{array}$ & \begin{tabular}{|c} 
MAX \\
RESISTIVITY \\
WITHIN J1 \\
INTERVAL
\end{tabular} & TD \\
\hline 26157212120000 & MALLON PRODUCTION CO & 4231 & -194 & -206 & 7 & 79 & 9 & 4510 \\
\hline 26157212130000 & MALLON PRODUCTION CO & 4485 & -188 & -213 & 16 & & 10 & 4750 \\
\hline 26157212140000 & ALCOIL EXPL INC & 3997 & -569 & -580 & 4 & 76 & 8 & 4680 \\
\hline 26157212150000 & ALCOIL EXPL INC & 4019 & -561 & -578 & 3 & 77 & 8 & 4695 \\
\hline 26157212170000 & LECLAIR-WESTWOOD INC & 3805 & -627 & -645 & 13 & 74 & 8 & 4500 \\
\hline 26157212180000 & LECLAIR-WESTWOOD INC & 3905 & -831 & -855 & 6 & 64 & 12 & 4796 \\
\hline 26157212190000 & LECLAIR-WESTWOOD INC & 3951 & -999 & -1011 & 4 & 69 & 10 & 5008 \\
\hline 26157212200000 & MALLON PRODUCTION CO & 4514 & -166 & -179 & 6 & & 7 & 4754 \\
\hline 26157212220000 & MALLON PRODUCTION CO & 4009 & -827 & -845 & 12 & 39 & 12 & 4842 \\
\hline 26157212230000 & EVANS ENERGY INC & 4125 & -925 & -934 & 4 & 64 & 11 & 5108 \\
\hline 26157212240000 & EVANS ENERGY INC & 4027 & -703 & -711 & 2 & 78 & 5 & 4855 \\
\hline 26157212250000 & EVANS ENERGY INC & 4010 & -582 & -588 & 2 & 84 & 4 & 4705 \\
\hline 26157212260000 & EVANS ENERGY INC & 3877 & -843 & -850 & 3 & & 5 & 4804 \\
\hline 26157212270000 & EVANS ENERGY INC & 4006 & -364 & -378 & 6 & 84 & 10 & 4453 \\
\hline 26157212280000 & EVANS ENERGY INC & 3951 & -700 & -718 & 5 & 71 & 13 & 4770 \\
\hline 26157212290000 & GEAR DRILLING CO & 3934 & -920 & -932 & 3 & & 8 & 4953 \\
\hline 26157212300000 & STRATA OIL CO INC & 4339 & -279 & -301 & 12 & & 11 & 4694 \\
\hline 26157212310000 & BWAB INC & 3915 & -830 & -859 & 14 & 67 & 12 & 4845 \\
\hline 26157212330000 & BEARTOOTH OIL \& GAS & 3840 & -529 & -548 & 10 & 74 & 12 & 4427 \\
\hline 26157212340000 & BWAB INC & 3989 & -565 & -582 & 9 & 80 & 7 & 4633 \\
\hline 26157212350000 & ALCOIL EXPL INC & 3992 & -562 & -582 & 7 & 74 & 6 & 4676 \\
\hline 26157212360000 & GEAR DRILLING CO & 3930 & -560 & -582 & 7 & 68 & 9 & 4570 \\
\hline 26157212370000 & GEAR DRILLING CO & 4014 & -903 & -907 & 0 & & 3 & 4971 \\
\hline 26157212380000 & BWAB INC & 3990 & -570 & -588 & 7 & 78 & 10 & 4650 \\
\hline 26157212390000 & BWAB INC & 3945 & -809 & -819 & 2 & 62 & 10 & 4830 \\
\hline 26157212400000 & TOLTEK DRLG CO & 4155 & -1261 & -1267 & 4 & & 10 & 5500 \\
\hline 26157212410000 & BWAB INC & 3990 & -848 & -852 & 1 & & 4 & 4937 \\
\hline 26157212420000 & BWAB INC & 3980 & -561 & -578 & 3 & 70 & 7 & 4575 \\
\hline 26157212430000 & CURRENTLY UNASSIGNED & 4001 & -415 & -424 & 6 & 80 & 7 & 4530 \\
\hline 26157212440000 & CURRENTLY UNASSIGNED & 3920 & -550 & -570 & 4 & & 10 & 4580 \\
\hline 26157212450000 & BWAB INC & 4072 & -1035 & -1055 & 4 & & 40 & 5180 \\
\hline 26157212460000 & CURRENTLY UNASSIGNED & 3898 & -551 & -558 & 4 & & 10 & 4520 \\
\hline 26157212470000 & BANNER DRLG CORP & 3831 & -710 & -723 & 4 & 62 & 15 & 4618 \\
\hline 26157212470001 & BANNER DRLG CORP & 3831 & & & & & & 630 \\
\hline 26157212480000 & GEAR DRILLING CO & 3969 & -901 & -904 & 2 & & 3 & 4967 \\
\hline 26157212490000 & BARFIELD OIL CORP & 4332 & -1324 & -1335 & 2 & 56 & 8 & 5765 \\
\hline 26157212500000 & BANNER DRLG CORP & 3833 & -707 & -726 & 11 & 64 & 13 & 4618 \\
\hline 26157212510000 & BANNER DRLG CORP & 3977 & -1031 & -1039 & 2 & 62 & 8 & 5100 \\
\hline 26157212520000 & CURRENTLY UNASSIGNED & 4098 & -1020 & -1034 & 4 & & 11 & 5172 \\
\hline 26157212530000 & SCHOLL \& RATLIFF COR & 3800 & -630 & -647 & 14 & 72 & 13 & 4506 \\
\hline 26157212540000 & CURRENTLY UNASSIGNED & 3828 & -675 & -679 & 1 & 68 & 3 & 4566 \\
\hline
\end{tabular}




\begin{tabular}{|c|c|c|c|c|c|c|c|c|}
\hline WELL ID & OPERATOR & $\begin{array}{c}\text { KB } \\
\text { ELEV }\end{array}$ & $\begin{array}{c}\text { TOP J } \\
\text { SUBSEA }\end{array}$ & $\begin{array}{l}\text { BASE J1 } \\
\text { SUBSEA }\end{array}$ & $\begin{array}{c}\text { J1 NET } \\
\text { THICKNESS }\end{array}$ & $\begin{array}{c}\text { INTERVAL } \\
\text { HUNTSMAN } \\
\text { SHALE } \\
\text { MARKER to } \\
\text { TOP OF J } \\
\end{array}$ & \begin{tabular}{|c|} 
MAX \\
RESISTIVITY \\
WITHIN J1 \\
INTERVAL
\end{tabular} & TD \\
\hline 26157212550000 & CURRENTLY UNASSIGNED & 4036 & -618 & -622 & 0 & 80 & 3 & 4760 \\
\hline 26157212570000 & C \& M OIL INC & 3825 & -715 & -730 & 6 & & 9 & 4613 \\
\hline 26157212570001 & C \& M OIL INC & 3825 & & & & & & 4614 \\
\hline 26157212580000 & H \& R EXPL \& PRODUCT & 4465 & -1319 & -1343 & 22 & 55 & 26 & 5855 \\
\hline 26157212590000 & BANNER DRLG CORP & 3824 & -706 & -721 & 0 & 64 & 5 & 4512 \\
\hline 26157212600000 & CURRENTLY UNASSIGNED & 4114 & -1102 & -1114 & 2 & 62 & 13 & 5295 \\
\hline 26157212610000 & CURRENTLY UNASSIGNED & 3821 & -631 & -639 & 4 & 68 & 8 & 4520 \\
\hline 26157212620000 & RATLIFF CORP & 3917 & -561 & -582 & 6 & 68 & 20 & 4600 \\
\hline 26157212630000 & GEAR DRILLING CO & 3988 & -818 & -832 & 6 & 62 & 13 & 4894 \\
\hline 26157212640000 & CURRENTLY UNASSIGNED & 4165 & -819 & -833 & 9 & & 10 & 5100 \\
\hline 26157212650000 & GEAR DRILLING CO & 3910 & -832 & -852 & 12 & 65 & 12 & 4810 \\
\hline 26157212660000 & TYLER ROCKIES EXPL L & 4007 & -585 & -592 & 2 & 77 & 5 & 4697 \\
\hline 26157212670000 & CURRENTLY UNASSIGNED & 4086 & -1036 & -1048 & 4 & 60 & 12 & 5200 \\
\hline 26157212680000 & BANNER DRLG CORP & 3827 & -711 & -717 & 2 & 66 & 9 & 4615 \\
\hline 26157212690000 & BANNER DRLG CORP & 3832 & -610 & -626 & 2 & 70 & 7 & 4510 \\
\hline 26157212700000 & GEAR DRILLING CO & 3984 & -834 & -848 & 10 & 61 & 15 & 4900 \\
\hline 26157212710000 & SCHOLL \& RATLIFF COR & 3926 & -598 & -620 & 8 & 72 & 18 & 4586 \\
\hline 26157212720000 & SUNRAY DX OIL CO & 3802 & -599 & -612 & 7 & 71 & 9 & 4470 \\
\hline 26157212730000 & BANNER DRLG CORP & 3836 & -674 & -685 & 0 & 65 & 5 & 4586 \\
\hline 26157212740000 & GREGORY & 4061 & -1149 & & & & & 5296 \\
\hline 26157212760000 & CURRENTLY UNASSIGNED & 3830 & -682 & -689 & 2 & 64 & 11 & 4624 \\
\hline 26157212780000 & SCHOLL \& RATLIFF COR & 3926 & & & & & & 4522 \\
\hline 26157212780001 & SCHOLL \& RATLIFF COR & 3926 & -574 & & & 72 & & 4520 \\
\hline 26157212790000 & SCHOLL \& RATLIFF COR & 3910 & -602 & -634 & 14 & 68 & 13 & 4569 \\
\hline 26157212820000 & MALLON PRODUCTION CO & 4145 & -205 & -220 & 5 & 66 & 10 & 4460 \\
\hline 26157212840000 & GEAR DRILLING CO & 4510 & -1320 & -1332 & 8 & 56 & 13 & 5871 \\
\hline 26157212850000 & GEAR DRILLING CO & 3978 & -873 & -886 & 6 & 64 & 15 & 4947 \\
\hline 26157212860000 & RATLIFF CORP & 4034 & -862 & -880 & 13 & 63 & 15 & 5005 \\
\hline 26157212870000 & RATLIFF CORP & 3972 & -570 & -589 & 8 & 72 & 8 & 4635 \\
\hline 26157212890000 & GEAR DRILLING CO & 4530 & -1469 & -1477 & 2 & 111 & 9 & 6020 \\
\hline 26157212900000 & YOUNT FOUNDATION INC & 4020 & -1098 & -1120 & 14 & 56 & 63 & 5222 \\
\hline 26157212910000 & CANNON DALE & 3833 & -715 & -720 & 8 & & 9 & 4621 \\
\hline 26157212920000 & GEAR DRILLING CO & 3826 & -715 & -729 & 4 & 61 & 10 & 4600 \\
\hline 26157212940000 & GEAR DRILLING CO & 4010 & -1068 & -1074 & 2 & 60 & 10 & 5150 \\
\hline 26157212970000 & YOUNT FOUNDATION INC & 4026 & -1102 & -1128 & 16 & 54 & 35 & 5225 \\
\hline 26157212980000 & GEAR DRILLING CO & 4113 & -1029 & -1034 & 2 & & 4 & 5200 \\
\hline 26157212990000 & YOUNT FOUNDATION INC & 4016 & & & & & & 5205 \\
\hline 26157213000000 & ASHBY ANDREW M & 4007 & -605 & & & & & 4680 \\
\hline 26157213010000 & ASHBY ANDREW M & 3971 & -609 & & & & & 4711 \\
\hline
\end{tabular}

